\title{
Identification and characterization of control candidates for Pseudogymnoascus destructans, the fungus that causes white-nose syndrome in bats
}

\author{
by \\ Emma Micalizzi
}

A thesis submitted to the Faculty of Graduate and Postdoctoral Affairs in partial fulfillment of the requirements for the degree of

Master of Science

in

Biology

Carleton University

Ottawa, Ontario

(C) 2018

Emma Micalizzi 


\section{Acknowledgements}

I would like to sincerely thank my supervisor Dr. Myron Smith for his generosity, support, guidance, knowledge, and sense of humour. I am truly indebted for all that he has taught and given me.

I would also like to thank George White and Dr. Tyler Avis for their advice and for isolating some of the antagonists to screen against $P$. destructans. Thank you to Jonathan Mack for his work morphologically identifying fungi and to my thesis committee members Dr. Keith Seifert and Dr. John Veirula for their expertise and advice. Thank you to Dr. Ashkan Golshani, Houman Moteshareie, and Daniel Burnside for providing the yeast deletion array, the GFPexpressing yeast, and for their advice and guidance. Thank you to Imelda Galván Márquez for her advice and instruction and thank you to Kaleigh Norquay and Craig Willis for providing hibernaculum soil. Thank you to Dr. Bruce McKay for the use of his flow cytometer, to Dr. Apollo Tsopmo for the use of his freeze-drier, and to Karl Wasslen for conducting the gas chromatography mass spectrometry. Thank you to Dr. David Overy and Amanda Sproule for their assistance in examining antifungal broths. Thank you to Dr. J.-P. Xu for providing the US15 strain of $P$. destructans and to Carolyn Babcock for providing the SH-991 and SH-864 strains. Thank you to Bodunde Oyetoran and Nayana De Silva for providing strains of plant pathogens. Finally, thank you to the Natural Sciences and Engineering Research Council of Canada (NSERC) for financial support for this project through a CGSM grant to me, as well as through an NSERC Discovery Grant to MLS. 


\section{Table of Contents}

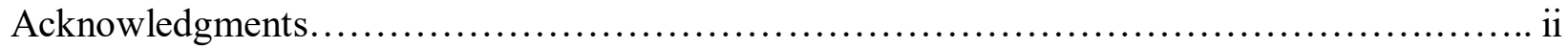

Abstract................................................................................ 1

General introduction............................................................. 2

Chapter 1: Identification of microbial antagonists of Pseudogymnoascus destructans.

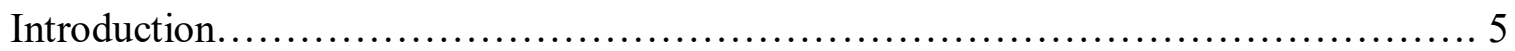

Materials and methods

Pseudogymnoascus strains................................................ 6

Isolation of antagonists........................................... 7

Bioassay for filamentous fungal and actinobacterial antagonists ............... 8

Bioassay for bacterial and yeast antagonists............................ 8

Assessing inhibition............................................... 8

Identification.................................................... 10

DNA extraction........................................................ 10

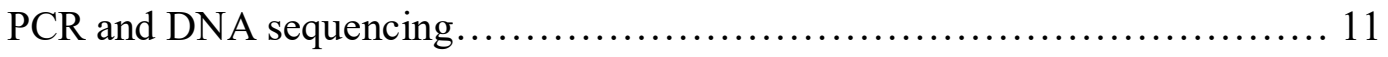

Shared airspace experiments........................................ 12

Volatile identification and characterization.............................. 12

Assessing activity of spent antagonist media.............................. 14

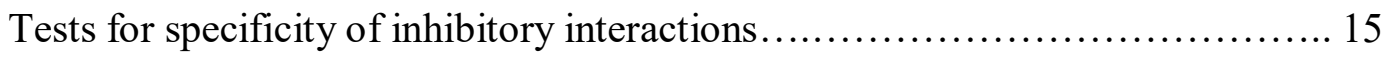

Results

Bioassays........................................................ 15

Antagonist identification............................................ 19

Antagonists acting through volatiles.................................. 20

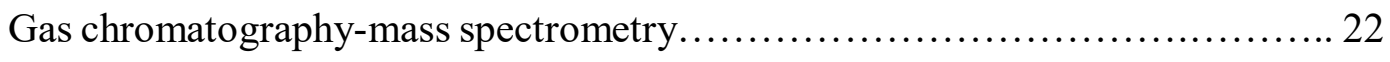

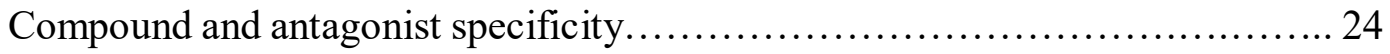

Discussion............................................................. 25

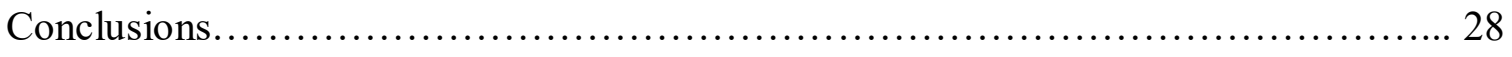

Chapter 2: Examination of antagonist metabolites.

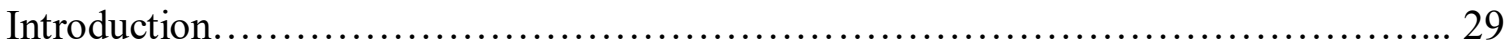


Materials and methods

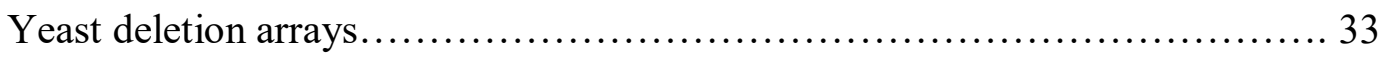

Follow-up to deletion arrays....................................... 34

Oxidative stress assay................................................. 35

Endocytosis assay................................................. 35

Cell cycle progression assay......................................... 36

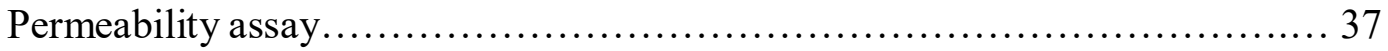

Cellular respiration assay............................................. 37

Gene expression assay............................................. 38

Statistical analysis................................................... 39

Results

Mutant sensitivity to volatile compounds................................ 39

Ontology terms enriched in sensitive mutants........................... 44

Follow-up to ontology searches

Oxidative stress assay.......................................... 46

Endocytosis assay......................................... 48

Cell cycle progression assay.................................. 49

Membrane permeability assay................................ 51

Cellular respiration assay.................................... 53

Gene expression assay...................................... 55

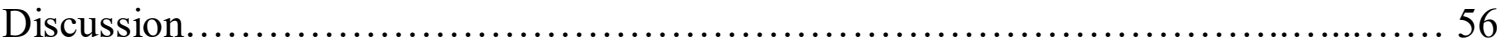

Conclusions............................................................ 64

Chapter 3: Testing the efficacy of microbial and volatile inhibitors of Pseudogymnoascus destructans in hibernaculum-like soil microcosms.

Introduction........................................................... 65

Materials and methods

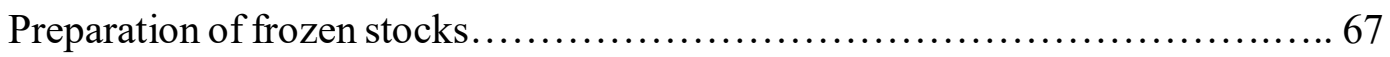

Microcosm soil....................................................... 68

Microcosms with microbial antagonists............................... 68

Microcosms with volatile compounds................................. 69 
Culture of volatile-treated microcosm soil............................... 69

Detection of $P$. destructans DNA in different soils............................ 69

qPCR detection of $P$. destructans in microcosms.......................... 70

Results

Microcosms with microbial antagonists................................. 71

Microcosms with volatile compounds................................... 73

Cultured microcosm soil........................................... 74

Detection of dead P. destructans...................................... 75

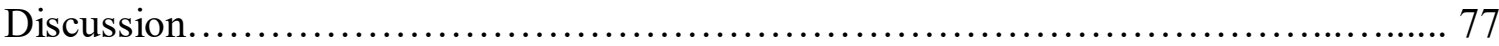

Conclusions................................................................ 80

Chapter 4: Antifungal applications to plant pathogens.

Introduction.................................................................. 81

Materials and methods

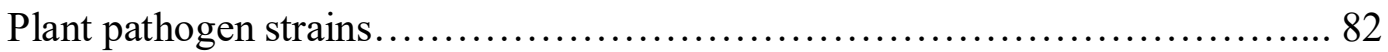

Preparation of plant pathogen stocks $\ldots \ldots \ldots \ldots \ldots \ldots \ldots \ldots \ldots \ldots \ldots \ldots \ldots \ldots . \ldots 2$

Test of antagonist broths for activity against plant pathogens................ 82

Test of antagonist broth activity over time............................. 83

Test of volatile activity against plant pathogens $\ldots \ldots \ldots \ldots \ldots \ldots \ldots \ldots \ldots \ldots \ldots \ldots$

Results

Screens of antagonist broths against plant pathogens...................... 84

Antagonist broth stability over time................................. 84

Screens of volatile compounds against $P$. destructans $\ldots \ldots \ldots \ldots \ldots \ldots \ldots \ldots \ldots . \ldots 5$

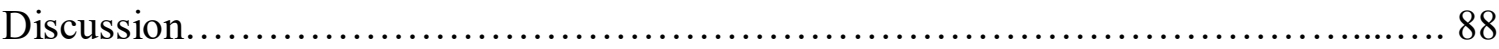

Conclusions............................................................. 89

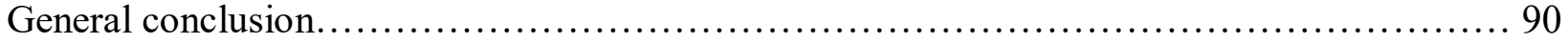

Appendix 1. Identification of microbial antagonists of Pseudogymnoascus destructans.......... 92

Appendix 2. Most probable identifications for each volatile compound detected through gas chromatography-mass spectrometry analysis of fungal and bacterial antagonists.............. 105

Appendix 3. Inhibition scores for 36 selected antagonists against different Pseudogymnoascus species. 
Appendix 4. Inhibitory concentrations for the filtered, spent media from each of 35 antagonist cultures.

Appendix 5. Inhibition of plant pathogens by cell-free broth from different microbial antagonistic strains. 109

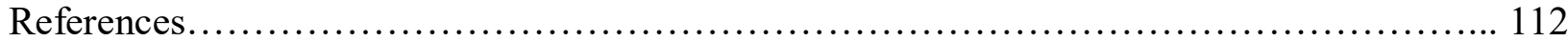




\section{Abstract}

Pseudogymnoascus destructans, the fungus that causes white-nose syndrome in hibernating bats, has caused unprecedented declines of bat populations in eastern North America and continues to threaten new populations as it spreads across the continent. In addition to growing on hibernating bats, $P$. destructans can grow as a saprotroph in the bat hibernaculum environment, which has likely contributed to the rapid spread and severity of the white-nose syndrome epidemic. In this thesis, we focus on the identification and characterization of candidate control agents that could target $P$. destructans in the hibernaculum environment. We first identify microbes that are strongly inhibitory to $P$. destructans in bioassays and show that some of these microbes act through the production of antifungal volatiles. We then use a yeast model to conduct preliminary analyses of the antifungal mode of action of the microbiallyproduced volatile compounds 2-methyl-1-butanol, 1-pentanol, propionic acid, and nonanal. We also simulate the hibernaculum environment with soil microcosms to assess the inhibitory activity of volatile compounds and microbial antagonists under hibernaculum-like conditions. Finally, we test the metabolites and volatile compounds that were inhibitory to $P$. destructans against a library of agriculturally-significant plant pathogens. Future research should further address the antifungal mechanisms of action of these compounds, their ability to inhibit $P$. destructans under hibernaculum conditions, and their employment as antifungals in general. 


\section{General introduction}

The primary focus of this research is to identify microbes and natural products that can inhibit Pseudogymnoascus destructans, the fungus that causes white-nose syndrome in bats. White-nose syndrome has caused unprecedented declines of bat populations in eastern North America and continues to threaten new populations as it rapidly spreads across the continent. $P$. destructans can grow in the environment in bat hibernacula and although further research is needed, an increasing body of evidence suggests that this environmental growth has contributed to the rapid spread and severity of the white-nose syndrome epidemic.

The ability of $P$. destructans to act as a saprotroph enables it to grow and persist in the environment (Lorch et al., 2013a; Lindner et al., 2011; Lorch et al., 2013b). Upon introduction

to a hibernaculum, $P$. destructans rapidly and broadly establishes itself, exponentially increasing its abundance with time (Frick et al., 2017). The ability of $P$. destructans to rapidly colonize hibernacula has not only created pathogenic reservoirs in these sites, but has also likely accelerated the expansion of $P$. destructans across the continent, as infected bats entering sites can shed conidia that persist and grow in the cave environment (Hoyt et al., 2015a; Frick et al, 2017). Although there have been no empirical studies of environment-to-bat transmission, several lines of evidence suggest that the environmental reservoir of $P$. destructans may contribute to infection of bats by the fungus. The fungal species found on bats reflect the assemblages in the environment (Vanderwolf et al., 2015) and airborne $P$. destructans spores can be detectable in bat hibernation sites (Kokurewicz et al., 2016), suggesting that conidia from environmental $P$. destructans can reach bats. Additionally, bats generally rid themselves of $P$. destructans in summer, and infection only becomes apparent once they begin hibernating in contaminated sites (Meteyer et al., 2011; Langwig et al., 2015; Frick et al., 2017). As bat 
populations have declined and population density has decreased, infection rates have remained high in early winter, suggesting that infection may occur from sources in the environment (Frick et al., 2017). Thus, the environmental growth of $P$. destructans may enable a cycle of infection and spread where infected bats contaminate the environment, and the contaminated environment infects bats. This is further intensified because the environmental reservoir of $P$. destructans has not decreased with declining bat populations (Frick et al., 2017) and may persist in the environment for over a century in the absence of bats (Reynolds et al., 2015). This long-term persistence increases the likelihood of extinction of susceptible bat species by preventing a density-dependent decrease in the transmission of disease and preventing recolonization of sites from which bats have been extirpated (Frick et al., 2017; Hoyt et al., 2015a). When taken together, this evidence suggests that the environmental growth of $P$. destructans may enable the rapid spread of white-nose syndrome across the continent, may contribute to the high rates of bat infection with $P$. destructans, and may enable the long-term persistence of $P$. destructans in hibernacula.

Because of the apparent importance of the environmental growth of $P$. destructans in the white-nose syndrome epidemic, we began our research by trying to identify biocontrol candidates that could be considered for the control of environmental $P$. destructans in bat hibernacula (Chapter 1). We isolated microbes from diverse environmental sources and used bioassays to screen these microbes for activity against $P$. destructans. This work was published in PLOS ONE (Micalizzi et al., 2017). Through this study, we identified many excellent antagonistic microbes that could be considered further as biocontrol candidates; however, we also recognized that some of the observed antagonistic effects likely resulted from the production of antifungal compounds by the antagonists. Using a natural product-based control strategy to 
target $P$. destructans could have some unique advantages over a biocontrol strategy, so we screened some of our top antagonists for the production of antifungal compounds and identified several antagonistic microbes that act through the production of inhibitory volatile compounds.

Volatile compounds are particularly promising for the chemical control of $P$. destructans in complex environments like bat hibernacula, so we examined the volatiles produced by selected antagonistic microbes in more detail. We identified the volatile compounds with gas chromatography mass spectrometry and then used a yeast model to conduct preliminary assessments on the antifungal mode of action of these compounds (Chapter 2).

Having identified microbial and volatile control candidates that effectively control $P$. destructans in bioassays, we also wanted to assess the efficacy of these control strategies in a simulated hibernaculum environment to assess their potential field applications (Chapter 3). We used hibernaculum soil to create hibernaculum-like microcosms and monitored the abundance of P. destructans over time in the presence of different control mechanisms. Surprisingly, we did not observe the decreases in abundance of $P$. destructans in these soil microcosm systems that we expected based on our earlier agar-based assays. We conducted follow-up assays to address the reason(s) for this discrepancy.

Finally, because we had identified antifungal volatile compounds, as well as microbial producers of secreted antifungal compounds, we decided to expand the scope of our project and determine if any of these compounds could inhibit agriculturally significant plant pathogens (Chapter 4). Information provided in this chapter indicate that some of the microbes that we identified produce compounds that may be useful in future work on the management of fungal pathogens in general, in addition to informing future strategies to combat the high rates of bat mortality due to white-nose syndrome. 


\section{Chapter 1: Identification of microbial antagonists of Pseudogymnoascus destructans}

This chapter has been published (Micalizzi et al., 2017) and is presented here with minor modifications. I was the primary researcher on this study and designed and carried out the experiments, analysed the data, wrote the first draft of the manuscript, and acted as the corresponding author. T.J. Avis, G.P. White, and M.L. Smith provided some of the antagonist microbes tested and J.N. Mack and G.P. White helped morphologically identify fungi. T.J. Avis helped design experiments and T.J. Avis and G.P. White helped edit the manuscript. M.L. Smith supervised all aspects of the project and served as the primary editor on the paper.

\section{Introduction}

Pseudogymnoascus destructans (Blehert \& Gargas) Minnis \& D.L. Lindner is the fungus that causes a deadly disease in hibernating bats known as white-nose syndrome (WNS) (Warnecke et al., 2012). P. destructans is believed to have been introduced to North America from Europe and was first discovered in New York in 2006 (Zukal et al., 2016; U.S. Fish and Wildlife Service, 2016). Over the past decade, $P$. destructans has caused extensive local extinctions and ten-fold reductions in affected North American bat populations (Frick et al., 2015). Further, $P$. destructans has rapidly spread to 33 U.S. states and 5 Canadian provinces (U.S. Fish and Wildlife Service, 2018) and is predicted to continue spreading (O'Regan et al., 2015), potentially threatening over half of all North American bat species (U.S. Fish and Wildlife Service, 2016). Such widespread loss of bats as prominent insectivores will undoubtedly have costly ecological, agricultural, and economic consequences (Boyles et al., 2011).

P. destructans causes WNS by colonizing the skin of hibernating bats, creating lesions and increasing the frequency with which bats emerge from torpor. This is often lethal as the 
increased energy demands of disrupted torpor can result in dehydration and emaciation before water or food is available (Verant et al., 2014). Further mortality may be caused by immune reconstitution inflammatory syndrome, where bats regain immune function after a period of hibernation-induced immunosuppression and have severe, lethal immune responses to $P$. destructans infection (Meteyer et al., 2012). After the winter, surviving bats can rid themselves of P. destructans (Langwig et al., 2015; Meteyer et al., 2011) and quickly heal their skin lesions (Fuller et al., 2011). However, because $P$. destructans persists in hibernacula by growing saprotrophically when bats are absent (Lorch et al., 2013b; Reynolds and Barton, 2014), it is possible that healthy bats could be infected when entering contaminated hibernacula (Langwig et al., 2015; Reynolds et al., 2015). While the role of the saprotrophic growth of $P$. destructans in the white-nose syndrome epidemic remains uncertain, model predictions have suggested that under some circumstances, reducing the growth of $P$. destructans in hibernacula may mitigate or prevent WNS-associated colony collapse (Reynolds et al., 2015; Meyer et al., 2016). Taken together, this suggests that targeting the growth of $P$. destructans in hibernacula may be an important part of managing the WNS epidemic.

In this study, we isolated a diversity of microbes from Ontario and Quebec, Canada, and screened for ones that inhibit $P$. destructans to identify potential biocontrol candidates and microbially-derived natural products that reduce the growth of $P$. destructans in a low temperature (hibernaculum-like) environment.

\section{Materials and methods}

\section{Pseudogymnoascus strains}

P. destructans strains US-15, SH-864, and SH-991 were obtained from Agriculture and Agrifood Culture Collection, Ottawa, ON, Canada. Unless specified otherwise, all assays used $P$. 
destructans strain US-15. P. roseus S8A2CN and P. pannorum S8A5ACS1 were isolated from soil samples in Gatineau, Québec. All cultures were grown and all assays were performed at $13 \pm$ $1{ }^{\circ} \mathrm{C}$, within the optimal temperature range for $P$. destructans (Verant et al., 2012).

Pseudogymnoascus cultures were stored in Potato Dextrose Broth (PDB) amended with 15\% sterile glycerol at $-80^{\circ} \mathrm{C}$.

\section{Isolation of antagonists}

Antagonists used in this study were from various sources and locations as listed in Appendix 1. Axenic antagonist cultures were grown in $5 \mathrm{ml} \mathrm{BD}$ Difco Potato Dextrose Agar (PDA) slants and stored in PDB amended with $15 \%$ sterile glycerol at $-80{ }^{\circ} \mathrm{C}$. Soil samples were collected from cold soils $\left(0-10^{\circ} \mathrm{C}\right)$ in April 2015 from Ottawa, Gatineau, and Toronto areas and frozen at $-20{ }^{\circ} \mathrm{C}$ until use. Approximately $1.5 \mathrm{~g}$ of soil was mixed with $10 \mathrm{ml}$ of sterile tap water and 10 - to 1000 -fold dilutions were plated onto various media including plates containing $0.2 \%$ chitin and 0.1× Vogel's salts (Vogel, 1956) to isolate chitinolytic fungi (Hsu and Lockwood, 1975; Murphy and Bleakley, 2012), LB Miller agar with $150 \mathrm{mg} \mathrm{L}^{-1}$ cycloheximide to isolate bacteria and select against fungi (Farh et al., 2015), PDA with $70 \mathrm{mg} \mathrm{L}^{-1}$ Rose Bengal to isolate slow-growing fungi (Bragulat et al., 1991), PDA with $100 \mathrm{mg} \mathrm{L}^{-1}$ ampicillin, $50 \mathrm{mg} \mathrm{L}^{-1}$ chloroamphenicol, and $75 \mathrm{mg} \mathrm{L}^{-1}$ streptomycin sulphate to isolate fungi without bacteria, and PDA alone to culture microbes non-specifically. Antagonists were also isolated from decomposing wood, birch bark, and hay. Additional antagonists were obtained from foam taken from the surface of the Rideau River (Ottawa, ON) and by leaving Petri plates open to the air. All antagonists isolations in this study were performed at $13 \pm 1{ }^{\circ} \mathrm{C}$. Further antagonists were isolated from compost and compost tea (Koné et al., 2010; Dionne et al., 2012) and from environmental samples isolated with DG-18 (Dichloran-Glycerol Agar) in the Ottawa region. 
Several strains of Bacillus and Trichoderma were from the culture collection of M.L. Smith (Providenti et al., 2009; Johnson et al., 2010).

\section{Bioassay for filamentous fungal and actinobacterial antagonists}

Aliquots of $P$. destructans cultures, macerated with a Waring blender and stored at -80 ${ }^{\circ} \mathrm{C}$ in PDB with 15\% glycerol, were thawed at room temperature and diluted in PDB to 5000 $\mathrm{CFU} / \mathrm{ml}$ in a sterile Eppendorf multichannel pipette reagent trough. A $50 \times 75-\mathrm{mm}$ flamesterilized glass microscope slide was dipped edgewise into the trough and used to stamp a narrow line of $P$. destructans inoculum onto the surface of PDA in a Petri plate. Perpendicular lines were stamped on PDA at an appropriate distance from the centre in a 55-mm (for assaying slow growing antagonists) or 90-mm (for fast growing antagonists) Petri plate so that a given antagonist, inoculated in the centre of the plate, would contact $P$. destructans at about day seven. Control plates were created by stamping $P$. destructans inoculum without an antagonist.

\section{Bioassay for bacterial and yeast antagonists}

PDA in 55-mm diameter Petri plates was pre-inoculated with $P$. destructans using a glass slide as described above to create two parallel lines of inoculum. Three days after $P$. destructans was inoculated, 7- $\mu$ l aliquots of a log phase antagonist culture in LB (bacteria) or PDB (yeast) were streaked in duplicate through both lines of $P$. destructans. LB broth and PDB were streaked through $P$. destructans on replicate plates as controls.

\section{Assessing inhibition}

Assay plates from antagonist screenings were photographed 14 days after $P$. destructans inoculation. Inhibition was quantified using image analysis to calculate the area of $P$. destructans. Images were scaled based on the size of the Petri plates and antagonist diameter was 
measured using the measure feature in ImageJ (Schneider et al., 2012). To aid in distinguishing $P$. destructans from background features, images were cropped to exclude as much background as possible and only one line of $P$. destructans was considered. Ilastik version 1.2.0 (Sommer et al., 2011) was used to distinguish $P$. destructans colonies from antagonist colonies and background. Simple segmentations for each image were exported to ImageJ where the greyscale image was thresholded with a value of 2 for each parameter. P. destructans colony area was calculated using the analyze particles feature of ImageJ with no parameters specified for size or circularity. Thresholded images were manually checked to ensure $P$. destructans was fully and exclusively detected and the reported area for P. destructans was the area of one streak multiplied by 2 or 3 , for plates stamped in duplicate or triplicate, respectively. Inhibition scores for each antagonist were reported as percent inhibition of $P$. destructans, relative to a noantagonist control. Percent inhibition was calculated as $\left(1-\frac{\text { Area }_{\text {treatment }}}{\text { Area }_{\text {control }}}\right) \times 100$, where Areatreatment refers to the area of $P$. destructans in the presence of the antagonist and Area ${ }_{\text {control }}$ refers to the area of $P$. destructans in the no-antagonist control. The percent inhibition for each antagonist, along with the respective day 14 area of $P$. destructans and antagonist diameter are provided in Appendix 1. The inhibition scores of $P$. destructans by an antagonist were ranked as $0=$ negligible or no (less than 50\%) inhibition of $P$. destructans; $1=$ considerable (between $50 \%$ and $85 \%$ ) inhibition of $P$. destructans; or $2=$ complete or nearly complete (greater than $85 \%$ ) inhibition of $P$. destructans. Additionally, if applicable, antagonistic ranks were qualified with: A $=P$. destructans inhibited the antagonist; $\mathrm{B}=$ the antagonist grew over $P$. destructans such that $P$. destructans colonies were no longer visible; and/or $\mathrm{C}=P$. destructans colonies were present, but considerably smaller than colonies on the control plates. A representative of each of these classifications and a control plate is shown in Figure 1.1. 


\section{Identification}

Isolates that inhibited $P$. destructans were identified, including all isolates that caused greater than $85 \%$ inhibition, by sequences of ITS rDNA (fungi), $16 S$ (bacteria) rDNA, and betatubulin (Penicillium sp.) DNA. Morphological identification was used to augment sequencebased identifications of filamentous fungi.

\section{DNA extraction}

DNA was extracted using a modified form of the protocol outlined by Lõoke and colleagues (2011). Antagonists were grown at room temperature in a 1.5-ml epitube containing 1 $\mathrm{ml}$ sterile PDB until the culture was visible throughout the tube. The cells were pelleted by centrifugation and resuspended in 100-150 $\mu 1$ of $200 \mathrm{mM}$ lithium acetate with $1 \%$ SDS. Approximately $15 \mathrm{mg}$ of $0.5 \mathrm{~mm}$ (for filamentous fungi or yeast) or $0.1 \mathrm{~mm}$ (for bacteria) glass beads were added to each epitube before the tubes were placed into a Fisher Scientific Isotemp waterbath at $70{ }^{\circ} \mathrm{C}$ for 10 minutes and subsequently cooled on ice. The epitubes were then shaken in a Retsch MM301 mixer mill at $20 \mathrm{~Hz}$ twice for 2 minutes each, separated by a 2minute pause, and then $300 \mu 1$ of ice-cold $95 \%$ ethanol was added before each tube was vortexed and left for 10 minutes. The epitubes were then centrifuged at 15,000 rpm for 3 minutes and the pellet was rinsed with $70 \%$ ethanol and dried in a Savant Speed Vac Concentrator before resuspending in $100 \mu 1$ of distilled water. The epitubes were centrifuged at $15,000 \mathrm{rpm}$ for approximately 15 seconds and $20 \mu \mathrm{l}$ of the supernatant was removed and stored at $-20{ }^{\circ} \mathrm{C}$ until use in PCR amplifications. 


\section{PCR and DNA sequencing}

The ITS region of filamentous fungi and yeast was amplified using ITS5 (5'GGAAGTAAAAGTCGTAACAAGG-3') or ITS9mun (5'-TGTACACACCGCCCGTCG-3') forward primers and ITS4 (5'-TCCTCCGCTTATTGATATGC-3') reverse primer (Egger, 1995; Toju et al., 2012; White et al., 1990). The $16 S$ region of bacterial samples was amplified using Bakt_341F (5'-CCTACGGGNGGCWGCAG-3') forward and Bakt_805R (5'GACTACHVGGGTATCTAATCC-3') reverse primer (Klindworth et al., 2013; Herlemann et al., 2011). The beta-tubulin gene of Penicillium antagonists was amplified using Bt2a (5'GGTAACCAAATCGGTGCTGCTTTC-3') forward primer and Bt2b (5'ACCCTCAGTGTAGTGACCCTTGGC-3') reverse primer (Glass and Donaldson, 1995). Standard PCR reactions contained approximately $2 \mu \mathrm{l}$ each of $10 \mu \mathrm{M}$ forward and reverse primers, $5 \mu 1$ of $10 \times$ Taq buffer (BioShop, Burlington, ON), $2 \mu 1$ of $25 \mathrm{mM} \mathrm{MgCl}_{2}, 2 \mu 1$ of 10 mM dNTPs (New England BioLabs, Whitby, ON), 1.25 units of Taq (New England BioLabs), approximately $100 \mathrm{ng}$ of template DNA, and sterile Milli-Q water to $50 \mu \mathrm{l}$. For filamentous fungal and yeast $I T S$, the PCR schedule was 5 minutes at $94{ }^{\circ} \mathrm{C}$, then 35 cycles each with 30 seconds at $94{ }^{\circ} \mathrm{C}, 56{ }^{\circ} \mathrm{C}$, and $72{ }^{\circ} \mathrm{C}$, then 7 minutes at $72{ }^{\circ} \mathrm{C}$. For bacterial $16 S$, the schedule was 10 minutes at $94{ }^{\circ} \mathrm{C}$, then 35 cycles each with 60 seconds at $94{ }^{\circ} \mathrm{C}, 57^{\circ} \mathrm{C}$, and $72{ }^{\circ} \mathrm{C}$, then 10 minutes at $72{ }^{\circ} \mathrm{C}$. The beta-tubulin PCR schedule was 3 minutes at $95^{\circ} \mathrm{C}$, then 35 cycles each with 30 seconds at $95{ }^{\circ} \mathrm{C}, 60^{\circ} \mathrm{C}$, and $72{ }^{\circ} \mathrm{C}$, then 7 minutes at $72{ }^{\circ} \mathrm{C}$. PCR products were purified using a Geneaid PCR DNA fragments extraction kit and sent to Génome Québec (Montréal, QC) for Sanger sequencing (Applied Biosystems - 3730xl DNA Analyzer). Forward and reverse sequences were aligned using ExPASy ClustalW and the NCBI nucleotide BLAST database was 
used to identify the microbes. DNA sequences were submitted to GenBank and accession numbers are given in Appendix 1.

\section{Assessing volatile production and activity}

\section{Shared airspace experiments}

A shared-airspace experiment was performed to assess if any of the antagonists that completely or uniformly inhibited $P$. destructans in bioassays acted through volatiles. A strip approximately $1 \mathrm{~cm}$ wide was cut out of the centre of a 90-mm PDA plate to create two separated pieces of agar. A thawed stock of $P$. destructans was diluted in PDB and approximately $1.3 \times 10^{4}$ CFUs were spread onto agar on one side of the plate. A small amount of antagonist (a small loopful for bacteria/yeast or a needleful for filamentous fungi) was suspended in $250 \mu 1$ of liquid medium (PDB for filamentous fungi and yeast, LB for bacteria) and $200 \mu 1$ of this suspension was spread onto the agar surface opposite of $P$. destructans. The plates were sealed with Parafilm and incubated at $13 \pm 1{ }^{\circ} \mathrm{C}$. The growth of $P$. destructans was monitored and compared to a control without an antagonist from 6 to 14 days after inoculation. The day 14 area of $P$. destructans and respective inhibition scores for each antagonist were calculated using ilastik (Sommer et al., 2011) and ImageJ (Schneider et al., 2012), as above. Based on inhibition scores, antagonist inhibition of $P$. destructans was scored as negligible, considerable, or complete/nearly complete, as described above.

\section{Volatile identification and characterization}

Headspace gas chromatography mass spectrometry (GC-MS) was used to analyse volatiles produced by the four microbes that had contact-independent inhibition of $P$. destructans after 14 days. Pantoea ananatis RFA4P2, Oidiodendron sp. PCA20P, Pantoea sp. OA1I3M, Cystofilobasidium capitatum RW3I1a, and a no-antagonist (blank) control were inoculated on 3- 
$\mathrm{ml}$ PDA slants inside headspace jars and grown for 5 days at $13 \pm 1{ }^{\circ} \mathrm{C}$. The headspace jars were covered with a double layer of sterile foil for the incubation period and sealed approximately 10 minutes before performing GC-MS. The GC-MS was done with an Agilent Technologies 7697A headspace sampler coupled to an Agilent Technologies 7820A gas chromatography system and an Agilent Technologies 5977E mass spectrometer detector. The vials were sampled at $33.9{ }^{\circ} \mathrm{C}$, the loop temperature was $45^{\circ} \mathrm{C}$ and the transfer line was $80{ }^{\circ} \mathrm{C}$. Samples were injected for gas chromatography in splitless mode. A $30 \mathrm{~m} \times 250 \mu \mathrm{m} \times 0.5 \mu \mathrm{m}$ DB-WAXetr column was used with helium carrier gas at a constant flow rate of $1 \mathrm{ml} / \mathrm{min}$. The oven temperature was held at 50 ${ }^{\circ} \mathrm{C}$ for 2 min and then increased at a rate of $10{ }^{\circ} \mathrm{C} / \mathrm{min}$ to $235^{\circ} \mathrm{C}$, where it was held for 5.5 minutes. Mass-spectrometry was performed with electron ionization, and identification of volatile compounds was performed by comparison to version 5 of the National Institute of Standards and Technology (NIST) spectra database.

Compounds identified by GC-MS were tested for inhibitory activity against $P$. destructans in bioassays. A lawn of approximately $2.6 \times 10^{4} \mathrm{CFUs}$ of $P$. destructans was inoculated onto the surface of $15 \mathrm{ml}$ of PDA in a 90-mm diameter Petri dish. Petri dishes were inverted and a $2.5-\mathrm{cm}$ diameter sterile Whatman 3 paper disc was placed on the lid of each dish. The filter paper was saturated with 10 or $100 \mu$ of 2-methyl-1-propanol (J.T. Baker Chemical Co., Phillipsburg NJ), 2-methyl-1-butanol (Sigma-Aldrich, Oakville ON), propanoic acid, or 1pentanol (BDH Chemicals, Toronto ON). The $10 \mu 1$ aliquots were diluted to $100 \mu \mathrm{l}$ in sterile distilled water, except for 1-pentanol, which was diluted in 95\% ethanol. Separate assays were done using $100 \mu 1 /$ disc of water or ethanol as carrier controls. Plates were sealed with Parafilm and incubated inverted at $13 \pm 1{ }^{\circ} \mathrm{C}$ for 14 days and growth of $P$. destructans was assessed. To test whether the inhibition of $P$. destructans was fungistatic or fungicidal, the paper discs were 
removed on day 14 and the lid was dried with a sterile Kimwipe. Plates were sealed with Parafilm and incubated at $13 \pm 1{ }^{\circ} \mathrm{C}$ for an additional 14 days, after which growth of $P$. destructans was assessed.

Additional dilution series of each volatile compound were performed as above and the minimum inhibitory concentration, where no growth of $P$. destructans was visible after 14 days, was determined to be $50 \mu 1$ for 1-pentanol, $10 \mu \mathrm{l}$ for propionic acid, $75 \mu 1$ for isobutyl alcohol, and $17.5 \mu \mathrm{l}$ for 2-methyl-1-butanol. To determine the minimum exposure time required for an antifungal effect, a lawn of $P$. destructans was plated as described above and exposed to twice the MIC values of each compound for 30 minutes, 1 hour, or 2 hours and 45 minutes. Plates were sealed with Parafilm for the volatile incubation, after which the plate lid was replaced and plates were left unsealed for 14 days at $13 \pm 1^{\circ} \mathrm{C}$. Percent inhibition of $P$. destructans was calculated using Image $\mathrm{J}$ and Ilastik, as described above.

\section{Assessing activity of spent antagonist media}

We screened antagonists for production of antimicrobial compounds that inhibit $P$. destructans. We used spent culture media from a subset of antagonists of $P$. destructans US-15 and screened these against $P$. destructans strains US-15, SH-864, and SH-991, P. roseus S8A2CN, P. pannorum S8A5ACS1, and Saccharomyces cerevisiae strain S288C. Thirty-five antagonists were each grown stationary in $250 \mathrm{ml}$ flasks with $50 \mathrm{ml}$ of PDB (fungi) or LB (bacteria) for 4 weeks at $13 \pm 1^{\circ} \mathrm{C}$. After this time, the culture medium was harvested and passed through a $0.2-\mu \mathrm{m}$ syringe filter and then $10 \times$ concentrated following lyophilisation. To assess inhibition of Pseudogymnoascus spp. and yeast, $50 \mu \mathrm{l}$ of cell-free filtrate was 1:1 serially diluted in $50 \mu \mathrm{l}$ of PDB (for Pseudogymnoascus spp.) or YPD (10 $\mathrm{g} \mathrm{L}^{-1}$ yeast extract, $20 \mathrm{~g} \mathrm{~L}^{-1}$ peptone, $20 \mathrm{~g} \mathrm{~L}^{-1} \mathrm{D}$-glucose; for yeast) in a 96-well microtiter plate before the addition of $150 \mu \mathrm{l}$ of PDB 
with approximately 100 CFUs Pseudogymnoascus sp. or YPD with approximately 150 yeast cells. Ten-times concentrated medium (PDB or YPD, as appropriate) was used as a carrier control for antagonist filtrates. Inhibition was assessed visually after 14 days of growth at $13 \pm 1$ ${ }^{\circ} \mathrm{C}$ (Pseudogymnoascus sp.) or 3 days of growth at $30{ }^{\circ} \mathrm{C}($ S. cerevisiae $)$ and was defined as the lowest concentration of spent medium at which no growth was visible.

\section{Tests for specificity of inhibitory interactions}

To test the specificity of the inhibition of $P$. destructans, we repeated bioassays using 36 of our top antagonists against two additional strains of $P$. destructans (SH-864 and SH-991) and two close relatives of $P$. destructans ( $P$. roseus $\mathrm{S} 8 \mathrm{~A} 2 \mathrm{CN}$ and $P$. pannorum $\mathrm{S} 8 \mathrm{~A} 5 \mathrm{ACS} 1)$. The bioassays were conducted as described above for P. destructans US-15; however, the concentration of Pseudogymnoascus spp. inoculum stamped onto the plates was adjusted for each strain so that after 14 days a continuous line of fungal mycelium was visible for each strain. The concentrations were approximately $11,300 \mathrm{CFU} / \mathrm{ml} P$. destructans $\mathrm{SH}-864,10,000 \mathrm{CFU} / \mathrm{ml}$ P. destructans SH-991, 11,100 CFU/ml P. roseus S8A2CN, and 8,700 CFU/ml P. pannorum S8A5ACS1. Inhibition scores were calculated and ranked as described for P. destructans bioassays.

\section{Results}

To screen for potential biocontrol candidates, we first obtained microbial isolates from local environmental samples and from culture collections. We co-inoculated one isolate per plate with $P$. destructans and classified each isolate based on an ability to inhibit $P$. destructans growth 14 days after inoculation (described in Methods). 
Inhibition scores against $P$. destructans by each bacterial, filamentous fungal, and yeast isolate were calculated based on $P$. destructans colony area in the presence of isolates (see Methods) and classified as negligible (less than $50 \%$ inhibition of $P$. destructans), considerable ( $50 \%$ to $85 \%$ inhibition), or complete/nearly complete (greater than $85 \%$ inhibition), as summarized in Table 1.1 and represented in Figure 1.1. Nearly 50\% of the 301 isolates examined were antagonistic to $P$. destructans, and over $15 \%$ completely or nearly completely inhibited growth of $P$. destructans (Table 1.1, Figure 1.2). Most of the isolates that inhibited $P$. destructans did so by creating a zone of inhibition surrounding themselves where P. destructans did not grow. However, other modes of inhibition were also evident. For example, some fastgrowing filamentous fungi grew over $P$. destructans colonies and induced a highly vacuolized appearance to $P$. destructans hyphae that was suggestive of programmed cell death (Figure 1.3; Biella et al., 2002), while the presence of some yeast isolates resulted in P. destructans colonies that remained uniformly small over the entire plate. For a tested subset of these inhibitory yeasts, this was a fungistatic effect since the inhibited $P$. destructans colonies resumed normal growth when transferred to a plate without the yeast. Only a few of the environmental isolates were inhibited by $P$. destructans (Table 1.1). 

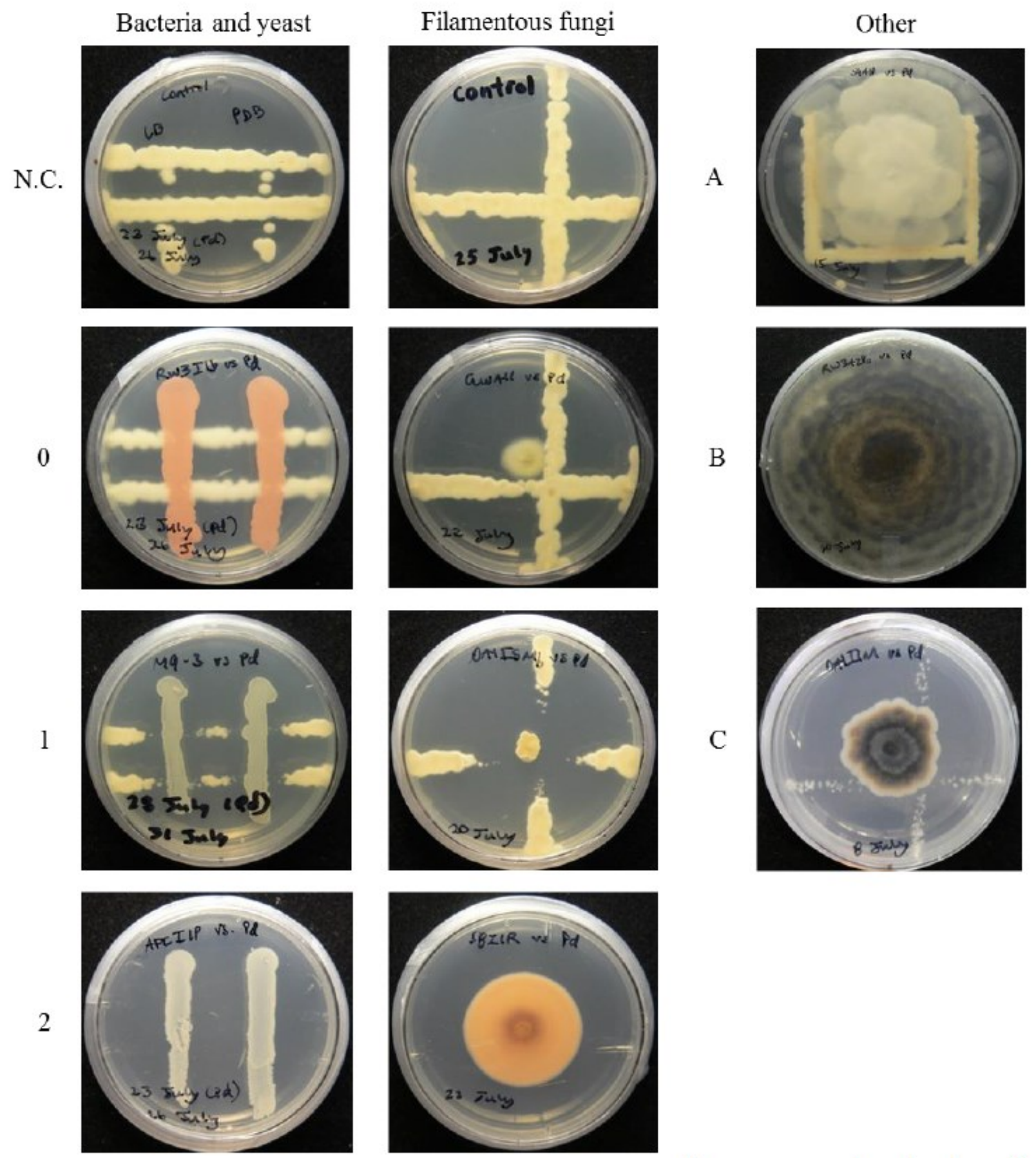

Figure 1.1. Representatives of each category of inhibition. $P$. destructans was inoculated on all plates as in the negative control (N.C.), and all photographs were taken 14 days after $P$. destructans inoculation. Classifications are (left and centre panels): (0) negligible $(<50 \%)$ inhibition, (1) considerable (50\% to $85 \%$ ) inhibition, (2) nearly complete/complete $(>85 \%)$ inhibition. Additionally, if applicable (right panel): (A) growth of the isolate is limited by $P$. destructans, (B) the isolate grew over $P$. destructans such that affected $P$. destructans colonies were no longer visible, (C) $P$. destructans colonies were present, but uniformly smaller than in the control plate. 
Table 1.1. Isolate inhibition of $\boldsymbol{P}$. destructans. Summary table showing the number of bacterial, filamentous fungal, and yeast isolates for each classification of inhibition 14 days after $P$. destructans inoculation.

\begin{tabular}{|c|c|c|c|c|}
\hline & Bacteria & Filamentous fungi & Yeast & Total \\
\hline Total screened & 130 & 158 & 13 & 301 \\
\hline Negligible $(<50 \%)$ inhibition & 75 & 75 & 6 & 156 \\
\hline Considerable ( $50 \%$ to $85 \%)$ inhibition & 27 & 60 & 5 & 92 \\
\hline $\begin{array}{l}\text { Complete/nearly complete }(>85 \%) \\
\text { inhibition }\end{array}$ & 28 & 23 & 2 & 53 \\
\hline P. destructans inhibited antagonist & 0 & 11 & 0 & 11 \\
\hline Antagonist grew over $P$. destructans & 0 & 31 & 0 & 31 \\
\hline Reduced $P$. destructans colony size & 8 & 25 & 5 & 38 \\
\hline
\end{tabular}

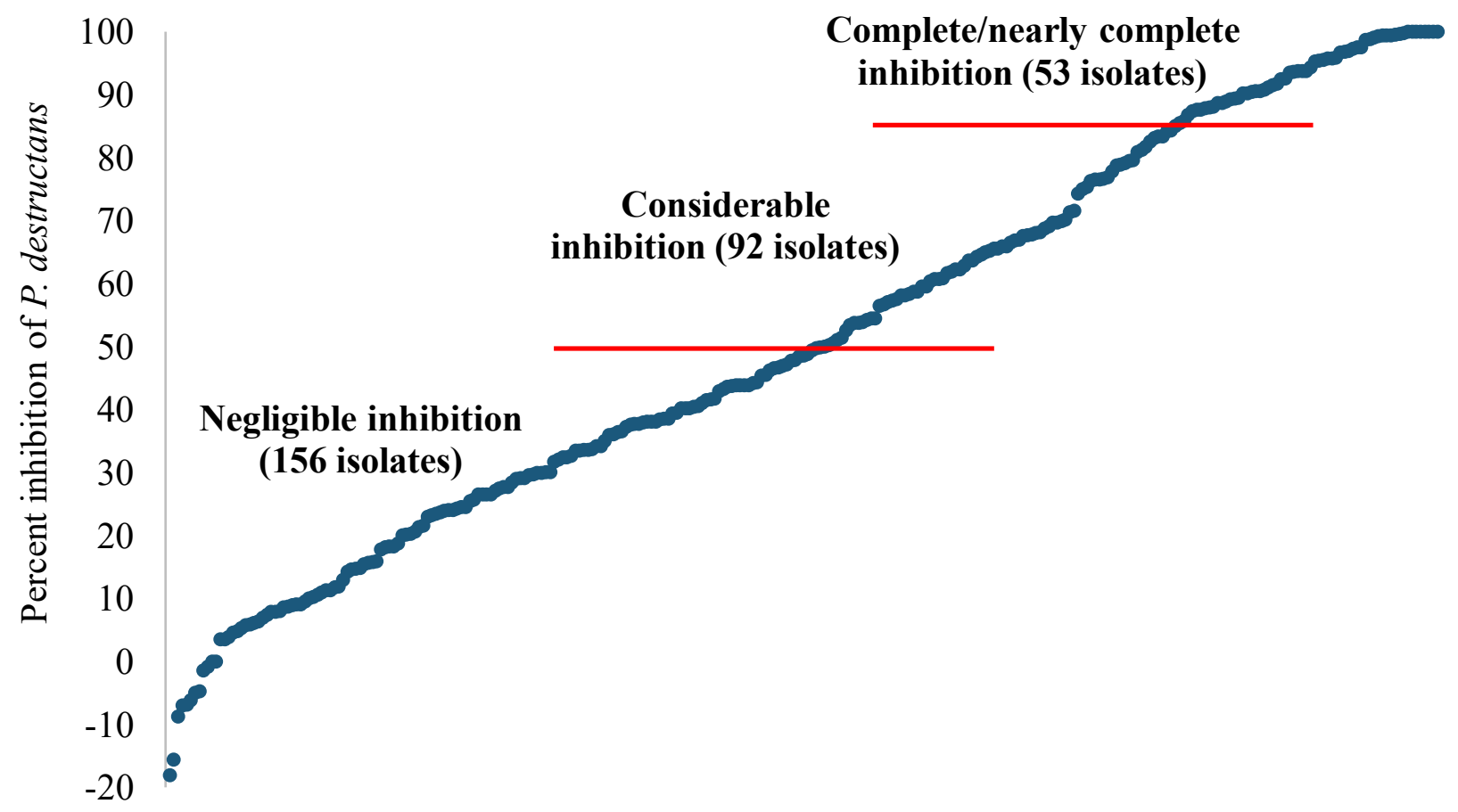

Filamentous fungal, yeast, and bacterial isolates

Figure 1.2. The distribution of inhibition of $\boldsymbol{P}$. destructans by tested microbes. Each blue dot represents a different microbe and the red lines indicate the cut-off values for each class of inhibition. 

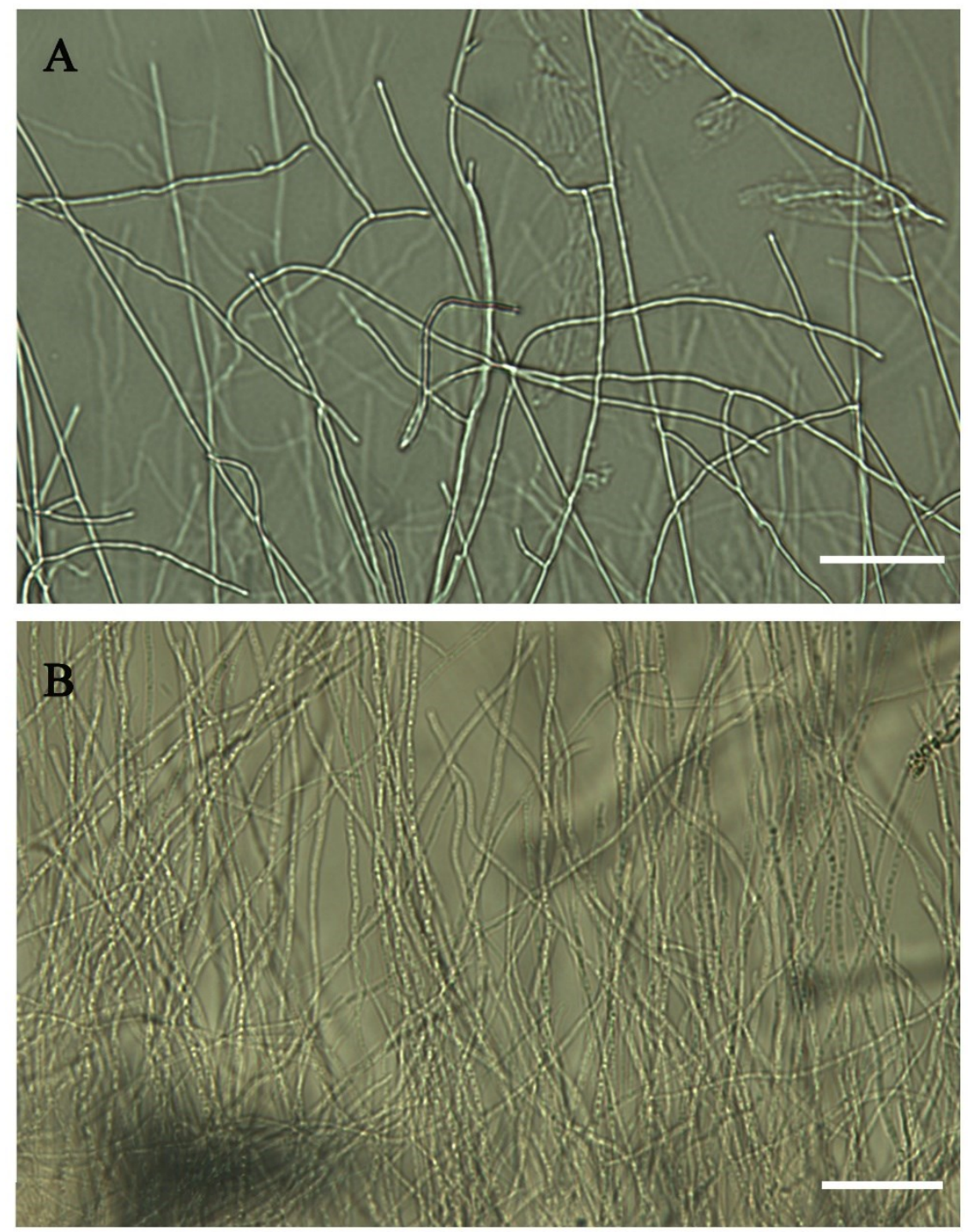

Figure 1.3. Representative image showing $P$. destructans vacuolization near antagonist hyphae. $P$. destructans was pre-inoculated for one week on a PDA-coated microscope slide before the slide was also inoculated with Penicillium crustosum BWA2P. After 4 days of antagonist growth, $P$. destructans hyphae had a healthy appearance on the colony side away from the antagonist (A), but had a vacuolized appearance suggestive of programmed cell death near antagonist hyphae (B). Scale bar represents $100 \mu \mathrm{m}$.

Isolates that inhibited the growth of $P$. destructans are henceforth referred to as 'antagonists'. The most inhibitory antagonists were taxonomically identified, where possible, to genus or species (see Methods, Appendix 1). The 28 most effective bacterial antagonists were from the genera Bacillus (17 strains), Pantoea (3 strains), Streptomyces (3 strains), Pseudomonas 
(2 strains), and 1 strain each from Rahnella, Arthrobacter, and Sphingobium. The 23 most inhibitory filamentous fungi were primarily from the genera Penicillium (11 strains) and Trichoderma (7 strains), and the genera Oidiodendron, Boeremia, Botrytis, and Phoma each had 1 representative. One strongly inhibitory antagonistic filamentous fungus (isolate RW3A2Pa) could not be identified. Yeast belonging to Cystofilobasidium (2 strains) were also among the most inhibitory antagonists. All antagonists of $P$. destructans were preserved as frozen glycerol stocks at $-80^{\circ} \mathrm{C}$.

We examined if antagonists that completely or uniformly inhibited $P$. destructans acted through volatile compounds by inoculating $P$. destructans separately from antagonists in a shared airspace (see Methods). Based on these assays, 7 of 28 antagonists tested produced volatiles that effectively reduced the growth of $P$. destructans for 6 to 10 days after inoculation. Volatiles from 2 of these antagonists (Oidiodendron sp. PCA20P and Pantoea sp. OA1I3M) caused considerable (50-85\%) inhibition and 2 (Pantoea ananatis RFA4P2 and Cystofilobasidium capitatum RW3I1a) caused complete or nearly complete (greater than 85\%) inhibition of $P$. destructans at 14 days after inoculation (Table 1.2). This suggests that at low temperatures, these antagonists constitutively produce volatile compounds that inhibit $P$. destructans. A representative of each class of inhibition by volatiles is shown in Figure 1.4. 
Table 1.2. Screen for inhibition of Pseudogymnoascus destructans by volatiles produced by selected antagonists. $P$. destructans and an antagonist were inoculated on separate pieces of agar within a single plate and incubated at $13 \pm 1{ }^{\circ} \mathrm{C}$. Inhibition was assessed at 6,10 and 14 days after inoculation and percent inhibition was calculated on day 14 as (1 Areatreatment $/$ Area control $_{1} \times 100$, based on the area of $P$. destructans in the presence of the antagonist (treatment) compared to in the no-antagonist control. The average $P$. destructans area in no-antagonist control was $2043.85 \mathrm{~mm}^{2}$. Antagonists were ranked based on their ability to inhibit $P$. destructans: $0=$ negligible $(<50 \%)$ inhibition, $1=$ considerable $(50 \%$ to $85 \%)$ inhibition, or $2=$ complete or nearly complete $(>85 \%)$ inhibition. Asterisks $(*)$ indicate cases where more pronounced inhibition of $P$. destructans was evident at day 6 and 10 but decreased by day 14 .

\begin{tabular}{|c|c|c|c|}
\hline Strain & $\begin{array}{c}\text { P. destructans Area } \\
\left(\mathbf{m m}^{2}\right)\end{array}$ & $\begin{array}{c}\text { Day 14 Percent } \\
\text { Inhibition }\end{array}$ & Rank \\
\hline RFA4P2 & 0.00 & 100.0 & 2 \\
\hline RW3I1a & 145.96 & 92.9 & 2 \\
\hline PCA20P & 672.15 & 67.1 & 1 \\
\hline OA113M & 781.32 & 61.8 & $1^{*}$ \\
\hline CIB T128 & 1222.48 & 40.2 & 0 \\
\hline DUST G & 1369.08 & 33.0 & 0 \\
\hline RW4A2P & 1391.97 & 31.9 & 0 \\
\hline APC11P & 1394.12 & 31.8 & 0 \\
\hline S9A1Cs1 & 1398.90 & 31.6 & $0^{*}$ \\
\hline OA1I1M & 1583.04 & 22.5 & 0 \\
\hline RW1I1Pa & 1616.44 & 20.9 & 0 \\
\hline 55407 & 1625.42 & 20.5 & 0 \\
\hline S4A3P & 1626.44 & 20.4 & $0^{*}$ \\
\hline S9A1R & 1699.65 & 16.8 & 0 \\
\hline S8A4Cs & 1743.78 & 14.7 & $0 *$ \\
\hline PCI2P & 1749.82 & 14.4 & 0 \\
\hline S8A1Cs1b & 1803.02 & 11.8 & 0 \\
\hline S5A2LC & 1818.50 & 11.0 & 0 \\
\hline S6A3ACS & 1834.22 & 10.3 & 0 \\
\hline APCI2P & 1922.01 & 6.0 & 0 \\
\hline S8I1R & 1946.96 & 4.7 & 0 \\
\hline RW1A1P1 & 1949.46 & 4.6 & 0 \\
\hline 95405 & 1951.98 & 4.5 & 0 \\
\hline BWA2P & 2040.81 & 0.1 & 0 \\
\hline GWA3a & 2047.64 & -0.2 & 0 \\
\hline RW6A1P & 2083.45 & -1.9 & 0 \\
\hline RW1A1P2 & 2187.00 & -7.0 & 0 \\
\hline F9-6 & 2209.09 & -8.1 & 0 \\
\hline
\end{tabular}


Control

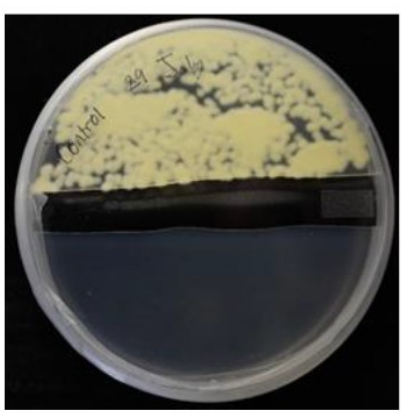

Negligible inhibition

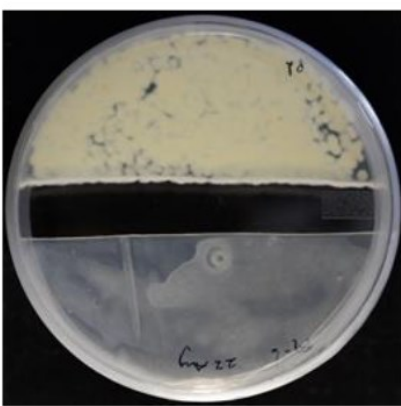

Considerable inhibition

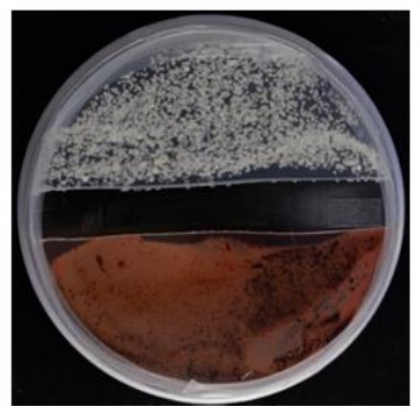

Complete / nearly

complete inhibition

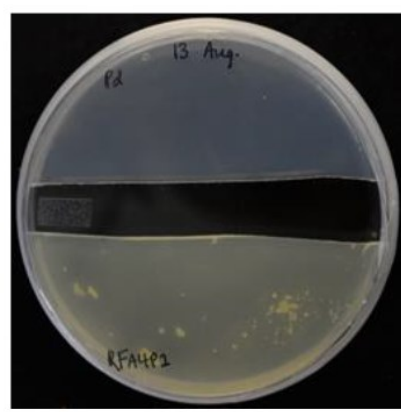

Figure 1.4. Evidence of inhibition of $P$. destructans by volatiles produced by antagonists. $P$. destructans and an antagonist were inoculated on separate pieces of agar within a single Petri plate. Photographs show $P$. destructans inoculated on the top and an antagonist on the bottom of the plate except for control plate (left), which contains $P$. destructans with no antagonist. Volatile production by antagonists was evident as considerable or complete growth inhibition of $P$. destructans. All photographs were taken 14 days after inoculation.

We conducted gas chromatography-mass spectrometry (GC-MS) to identify volatile compounds produced by the antagonists that inhibited $P$. destructans 14 days after inoculation. Volatile inhibitory compounds were identified in the headspace jars for three of the four antagonists that were analysed with GC-MS. We detected 2-methyl-1-propanol for C. capitatum RW3I1a and Pantoea sp. OA1I3M. We also detected 2-methyl-1-butanol for C. capitatum RW3I1a. Propanoic acid and 1-pentanol were detected for P. ananatis RFA4P2. Other compounds appeared to be present in samples but could not be conclusively identified. Oidiodendron sp. PCA20P did not produce any detectable volatiles, suggesting that unidentified factors are required to induce volatile production in this antagonist. The most probable identification for each compound, along with the corresponding match scores and probability scores are included in Appendix 2. 
Compounds tentatively identified through GC-MS were screened in bioassays to determine their ability to inhibit $P$. destructans. All four compounds tested (2-methyl-1propanol, 2-methyl-1-butanol, propanoic acid, and 1-pentanol) completely inhibited $P$. destructans growth for the 14-day experimental period when $100 \mu 1$ of compound was added. Only propanoic acid was completely inhibitory when $10 \mu 1$ of compound was applied. These compounds appear to be fungicidal since completely inhibited $P$. destructans did not resume growth after the compounds were removed. The ethanol control (carrier solvent for $10 \mu 1$ 1pentanol assay) also mildly affected $P$. destructans growth such that after 14 days, the average colony diameter was approximately $30 \%$ smaller than in the water control.

We also examined the effect of exposure time on the inhibition of $P$. destructans by volatile compounds. $P$. destructans was exposed to each volatile compound for 30,60 , or 165 minutes and then inhibition was assessed after 14 days of growth. 2-methyl-1-propanol strongly inhibited $P$. destructans with only 60 minutes of exposure and all compounds except 2-methyl-1butanol caused complete or nearly complete inhibition of $P$. destructans with less than three hours of exposure (Table 1.3).

Table 1.3. The effect of exposure time on the inhibition of $P$. destructans by four volatile compounds. $P$. destructans was inoculated onto agar plates and exposed separately to twice the minimum inhibitory concentration of each volatile compound for 30,60 , or 165 minutes. The volatiles were removed and the plate was incubated at $13 \pm 1{ }^{\circ} \mathrm{C}$ for 14 days. The percent inhibition of $P$. destructans in each condition is shown below and was calculated as ( 1 Areatreatment $/$ Area $\left._{\text {control }}\right) \times 100$, based on the day 14 area of $P$. destructans in the presence of the volatiles (treatment) compared to in a no-volatile control.

\begin{tabular}{|c|c|c|c|c|}
\hline Time (min) & 2-methyl-1-butanol & 2-methyl-1-propanol & 1-pentanol & Propionic acid \\
\hline 30 & $32.5 \%$ & $31.0 \%$ & $-14.3 \%$ & $-7.9 \%$ \\
\hline 60 & $37.2 \%$ & $85.2 \%$ & $17.6 \%$ & $7.8 \%$ \\
\hline 165 & $47.5 \%$ & $100 \%$ & $99.9 \%$ & $100 \%$ \\
\hline
\end{tabular}


We next conducted bioassays to examine the inhibitory specificity of 36 of the most effective antagonists. For these, we repeated the bioassays that we performed with our original strain of $P$. destructans against two additional strains of $P$. destructans and representatives of the closely related species, Pseudogymnoascus pannorum and Pseudogymnoascus roseus. Of the 36 antagonists tested in bioassays, 35 inhibited both additional strains of $P$. destructans, with 29 causing complete or nearly complete inhibition in both strains. Only 16 antagonists inhibited growth of $P$. roseus and/or $P$. pannorum, with 3 of these causing complete or nearly complete inhibition in one or both strains (Appendix 3).

We also qualitatively assessed whether our best antagonists could produce antimicrobial products that inhibit $P$. destructans. We grew 35 of our top antagonists in axenic liquid cultures and screened the spent media for activity against the above mentioned five Pseudogymnoascus strains and, in addition, Saccharomyces cerevisiae. Many of our antagonists produced inhibitory compounds and, similar to bioassays, $P$. destructans strains were considerably more sensitive than other species tested (Appendix 4). Spent media from 18 of 35 antagonists tested inhibited at least one of the three $P$. destructans strains, and nine of these did not inhibit other Pseudogymnoascus species or brewer's yeast.

Inhibition scores for the 27 antagonists that were tested in both bioassays and spent media screens were not always congruent and some antagonists appear to have context-dependent induction and/or effects of inhibitory compounds. For example, there were 13 antagonists that inhibited all three strains of $P$. destructans in bioassays, while the respective spent culture medium caused no inhibition of $P$. destructans. Conversely, there were seven antagonists that caused negligible inhibition of $P$. roseus and/or $P$. pannorum in bioassays, while their spent culture medium was inhibitory to $P$. roseus and/or $P$. pannorum. Nevertheless, it is notable that 
the culture medium from several antagonists, including Phoma sp. OA1I1M, Sphingobium sp. S8A4Cs, Trichoderma harzianum RW1A2P, and Paecilomyces inflatus PCA5P, caused very strong inhibition in all three strains of $P$. destructans while causing low inhibition of $P$. roseus, $P$. pannorum, and yeast. The inhibitory compounds produced constitutively by these antagonists could be considered further as candidate natural products to inhibit growth of $P$. destructans in bat hibernation sites.

\section{Discussion}

The white-nose syndrome that is caused by $P$. destructans has decimated eastern North American bat populations and is spreading across the continent (Warnecke et al., 2012; U.S. Fish and Wildlife Service, 2016; O'Regan et al., 2015). Saprotrophic growth of $P$. destructans in cool hibernacula may contribute to perpetuating the WNS epidemic (Reynolds et al., 2015) and thus may facilitate the infection or reinfection of healthy bats. In an effort to find biocontrol agents that will reduce the abundance of $P$. destructans in bat hibernacula, we isolated microbes from diverse environmental samples and tested them for inhibitory activity against $P$. destructans. We identified 145 microbes that inhibited the growth of $P$. destructans to some extent, and 53 of these completely or nearly completely inhibited $P$. destructans.

In the past decade since $P$. destructans was discovered, only a few microbes capable of inhibiting $P$. destructans have been identified: Rhodococcus rhodochrous (Cornelison et al., 2014b), Trichoderma polysporum, Trichoderma harzianum (Zhang et al., 2015), and Pseudomonas spp. (Hoyt et al., 2015b). These microbes are being studied for their biocontrol potential, and our study adds nearly 150 candidate biocontrol agents to this list, Additionally, we expand the list of natural products (Zhang et al., 2015; Cornelison et al., 2014a; Raudabaugh and Miller, 2015; Boire et al., 2016; Chaturvedi et al., 2011b) that could be of potential use in 
controlling $P$. destructans in bat caves. We also report on 4 volatile organic compounds that appear to have a rapid fungicidal effect on $P$. destructans. All 4 of these compounds have previously been reported to be produced by fungi (e.g. Jurjevic et al., 2008; Sánchez-Ortiz et al., 2016; Stinson et al., 2003b) and to have at least some degree of inhibitory activity against fungi (e.g. Cruz et al., 2012; Yun and Lee, 2016; Zunino et al., 2015; Braun et al., 2012). Although differences in methodologies preclude making quantitative comparisons between the antagonists identified in this study and the antagonists of $P$. destructans that have been previously identified, the most notable finding from our study is the relatively high frequency of microbes that we identified that cause complete or nearly complete inhibition of $P$. destructans. While few of the previously identified antagonists have completely inhibited growth of $P$. destructans, we identified five bacterial and four filamentous fungal isolates that did so in bioassays or volatile tests. Additionally, while a bacterium has been reported that inhibits $P$. destructans through volatiles (Cornelison et al., 2014b), we novelly identify microbes that produce inhibitory volatiles without induction.

The microbes that we identified have several promising features as biocontrol candidates in eastern North America. First, most of our top antagonists are microbes that already occur in Ontario and Quebec that present a lower risk than introducing foreign, potentially invasive species. Second, many of our top antagonists displayed antifungal activity at about $13{ }^{\circ} \mathrm{C}-\mathrm{a}$ temperature that represents the average temperature of North American bat hibernacula. Third, several of our top antagonists constitutively secrete compounds that inhibit $P$. destructans at concentrations that are non-inhibitory to close relatives and to $S$. cerevisiae, suggesting the possibility that these antifungal agents may have some degree of specificity towards $P$. destructans. In addition, in both bioassays and liquid media screens, $P$. destructans was more 
sensitive to inhibition than close relatives, again suggesting the possibility that there may be a reduced risk of non-target effects from our antagonists. Fourth, we identified microbes that inhibit the growth of $P$. destructans by seemingly different modes. For example, Trichoderma and fast-growing filamentous fungal antagonists typically grew over and appeared to induce programmed cell death of $P$. destructans (Biella et al., 2002), indicating cell proximity/contact as a main mode of action, whereas most of our top antagonists secreted water-soluble inhibitors, indicating antibiosis as a main mode of action. Several antagonists also produced volatiles at hibernaculum-like temperatures that inhibit $P$. destructans. A diversity of modes of action provides the possibility of creating a stable biocontrol strategy that targets $P$. destructans through multiple mechanisms. Finally, our high success rate of isolating native biocontrol candidates suggests that as $P$. destructans continues to spread across the continent, additional local biocontrol candidates can be identified that may reduce the growth and persistence of $P$. destructans in hibernacula.

Another interesting aspect of our findings is that several antagonists that we identified are not known to produce antifungal compounds. To our knowledge, antifungals have not been characterized from species of Boeremia, Phialosimplex, Ramularia, or Sphingobium, all of which secreted inhibitors of $P$. destructans. Similarly, only preliminary characterizations of antifungals are reported for species of Oidiodendron (Hosoe et al., 1999) and Cystofilobasidium (Lutz et al., 2011). This suggests the possibility that some of our top antagonists may produce novel antifungals, which could have applications both within and beyond controlling $P$. destructans.

Although we identified many potential biocontrol agents of $P$. destructans, an important limitation of this study is that it only addressed inhibition of $P$. destructans under controlled 
laboratory conditions. Future challenges to developing a biocontrol of white nose syndrome are to find antagonistic organisms that selectively inhibit growth of $P$. destructans in natural hibernacula. Considering the high proportion of microbes that inhibited $P$. destructans in our tests, it is surprising that a biocontrol of $P$. destructans has not arisen naturally. It is possible that the effects of natural antagonists are limited by an insufficient abundance and nutritional augmentation of hibernaculum sediment may be necessary to support greater antagonist growth. To explore this further, we will examine $P$. destructans-antagonist interactions in hibernaculumlike soil microcosms.

\section{Conclusions}

We identified over 100 microbes that inhibit the growth of $P$. destructans in a lowtemperature laboratory setting. These antagonistic microbes inhibit $P$. destructans with secreted compounds, by contact inhibition, or through volatiles. Future research is needed to validate potential biocontrol strategies under hibernaculum conditions. Our results suggest that local microbes can be a source of candidate biocontrol agents to reduce the abundance of the causal agent of white-nose syndrome in bat hibernation sites and remediate bat colony collapse. 


\section{Chapter 2: Examination of antagonist metabolites}

Pseudogymnoascus destructans is the fungus that causes a deadly disease in hibernating bats known as white-nose syndrome. In addition to colonizing the skin of hibernating bats, $P$. destructans can grow as a saprotroph in bat hibernacula (Lorch et al., 2013a; Lindner et al., 2011; Lorch et al., 2013b). A control agent that targets environmental P. destructans could contribute to managing the white-nose syndrome epidemic by potentially reducing the rate of bat infection and mortality, as well as the extent of $P$. destructans spread and persistence (Hoyt et al., 2015a; Frick et al, 2017; Reynolds et al., 2015).

Out of many possible control strategies, the use of microbial volatile compounds is especially promising for the chemical control of $P$. destructans in bat hibernacula, due to their ability to diffuse through spaces, their biodegradability, and their low environmental persistence (Wang et al., 2013). Additionally, volatiles can be effective fumigants in diverse and textured environments (e.g. Strobel et al., 2001; Mercier and Jiménez, 2007), and have been shown to be effective for treating agricultural soils (e.g. Stinson et al., 2003a). We and others have previously identified several volatile compounds that inhibit $P$. destructans in bioassays (Cornelison et al., 2014a; Padhi et al., 2016; Micalizzi et al., 2017) and that may be promising for the environmental control of $P$. destructans. To reduce off-target effects, these volatiles could be used as fumigants in bat hibernacula during summer months when bats are absent; however, an understanding of their antifungal mechanism of action is one of several knowledge gaps precluding field trials at this time. The focus of this chapter is to conduct preliminary characterizations of the antifungal mechanism of action of four volatile compounds that inhibit 
P. destructans: 2-methyl-1-butanol, 1-pentanol, propionic acid, and nonanal. The structures of these compounds are shown in Figure 2.1.

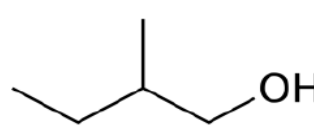

2-methyl-1-butanol

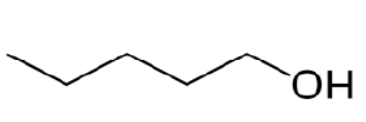

1-pentanol<smiles>CCC(=O)O</smiles>

Propionic acid

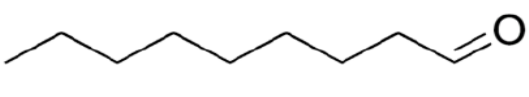

Nonanal

Figure 2.1. Structures of the four volatile compounds examined in this chapter.

We initially detected 2-methyl-1-butanol as a volatile compound produced by the yeast Cystofilobasidium capitatum (Micalizzi et al, 2017). 2-methyl-1-butanol, also known as active amyl alcohol, is a fusel alcohol produced at low levels during fermentation and widely present in many fermented foods and beverages (Kim et al., 2017, Hazelwood et al., 2008). In S. cerevisiae, 2-methyl-1-butanol is produced through native amino acid synthesis pathways (Cann and Liao, 2010) or through isoleucine catabolism via the Ehrlich pathway (Hazelwood et al., 2008). As a by-product of amino acid catabolism, 2-methyl-1-butanol may function as a quorumsensing compound and can induce filamentation in yeast (Hazelwood et al., 2008; Dickinson, 2008). There are several reports of 2-methyl-1-butanol having antifungal activity (e.g. Braun et al., 2012; Rezende et al., 2015; Fialho et al., 2011); however, only preliminary work has been conducted on its antifungal mode of action, which suggested that 2-methyl-1-butanol may increase membrane permeability and cause oxidative stress (Rezende et al., 2015).

1-pentanol, also called $n$-amyl-alcohol, is a straight-chain alcohol that we detected in volatiles from Pantoea ananatis. Like 2-methyl-1-butanol, 1-pentanol is considered a fusel alcohol and is found in fermented beverages (Kim et al., 2017); however, the natural biosynthesis of 1-pentanol is not well-understood (Cann et al., 2010). There are only a few reports on the antifungal activity of 1-pentanol (e.g. Liouane et al., 2009; Zunino et al., 2015), 
and while high-throughput screens have been conducted to elucidate its antifungal mechanism of action, the disruption of pathways identified in these screens has not been validated with secondary assays. Nevertheless, these screens suggest that genes related to vacuolar function, cell cycle and DNA processing, gene expression, and metabolism could be required for tolerance (Fujita et al., 2004; Fujita et al., 2006). As a medium-length straight-chain alcohol, 1-pentanol could also have antifungal effects by increasing membrane fluidity and permeability (Weber and de Bont, 1996).

In addition to 1-pentanol, we detected propionic acid in the volatiles of Pantoea ananatis. Propionic acid is widely used fatty acid that is generally recognized as safe (GRAS) by the U.S. Food and Drug Administration (2017). Industrially, hundreds of thousands of tonnes of propionic acid are produced annually, primarily for use as a preservative in foods and animal feeds, but also as a flavouring agent and in the synthesis of perfumes, herbicides, and pharmaceuticals (Bhatia and Yang, 2017; Ahmadi et al., 2016). Under natural circumstances, propionic acid is produced as an end-product of fermentation in Propionibacterium and other bacterial genera (Bhatia and Yang, 2017; Goswani and Srivastava, 2001; Ahmadi et al., 2016; Liu et al., 2012). Although the antifungal activity of propionic acid is well-known, several different modes of action have been proposed. Many have assumed the antimicrobial activity of propionic acid occurs through its effects as a weak fatty acid, increasing membrane permeability and acidifying the cytoplasm (Ahmadi et al., 2016; Ferreira et al., 1997; Davidson et al., 2002). However, recent work in Saccharomyces cerevisiae did not find an increase in membrane permeability with propionic acid treatment and found that intracellular $\mathrm{pH}$ alone cannot explain inhibition by propionic acid (Ullah et al., 2012). Genome-wide screens have suggested that both the regulation of intracellular $\mathrm{pH}$ through vacuolar acidification and the degradation of proteins through the 
multivesicular body pathway are important for propionic acid resistance (Mira et al., 2009). However, others have asserted that propionic acid acts through the generation of reactive oxygen species and mitochondrial-mediated apoptosis (Yun and Lee, 2016), while further research has shown that propionic acid inhibits glucose metabolism through indirect inhibition of the pyruvate dehydrogenase complex (Brock and Buckel, 2004). It is possible that propionic acid has multiple modes of action, or has different modes of action at different concentrations.

Cornelison et al. (2014a) reported on production of volatile nonanal from Rhodococcus rhodochrous. While we did not detect this volatile in any of our screens, we included it in further assays because it was reported to inhibit $P$. destructans. Nonanal is an aldehyde produced by plants and bacteria. While little is known about its biosynthesis, it is likely produced through the oxidation of $\mathrm{C}_{18}$ unsaturated fatty acids (oleic acid; Schulz and Dickschat, 2007; Dudareva et al., 2013). Although there are additional reports of nonanal having antifungal activity (e.g. Fernando et al., 2005; Kobaisy et al., 2001; Rajer et al., 2017), its mechanism of action has not been wellstudied. To the best of our knowledge, there is only one report on its antifungal mode, which showed that nonanal decreased membrane stability and increased membrane permeability in Penicillium cyclopium (Zhang et al., 2017).

To contribute to developing candidate natural products that could be used to target the environmental growth of $P$. destructans in hibernacula, we conducted preliminary examinations of the antifungal mechanisms of action of these four antifungal volatiles, using brewer's yeast (Saccharomyces cerevisiae) as a model. 


\section{Materials and methods}

\section{Yeast deletion arrays}

To detect genes involved in the volatiles' modes of action, a yeast deletion array was used. The array contained approximately 4300 haploid gene deletion strains derived from $S$.

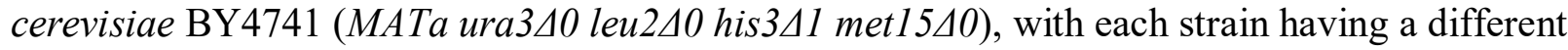
non-essential gene deleted (Tong et al., 2001), and was pinned onto array plates containing YPD agar (10 $\mathrm{g} \mathrm{L}^{-1}$ yeast extract, $20 \mathrm{~g} \mathrm{~L}^{-1}$ peptone, $20 \mathrm{~g} \mathrm{~L}^{-1}$ D-glucose, and $20 \mathrm{~g} \mathrm{~L}^{-1}$ agar) supplemented with $200 \mu \mathrm{g} \mathrm{ml}^{-1} \mathrm{G} 418$ sulphate. The lids of the array plates were lined with Whatman chromatography paper and the paper was wetted with $1 \mathrm{ml}$ of water mixed with volatile compounds at the following concentrations: $100 \mu 1$ of propionic acid, $150 \mu 1$ of 2 methyl-1-butanol, $150 \mu 1$ of 1-pentanol, or $2 \mu 1$ of nonanal. To ensure that the compounds were added uniformly to the chromatography paper, $0.1 \%$ Tween 80 was used in the epitubes to emulsify the water mixtures containing 2-methyl-1-butanol, 1-pentanol, and nonanal. The plates were sealed with Parafilm and incubated inverted at $30{ }^{\circ} \mathrm{C}$ for 2 days. Plates were imaged and candidate sensitive mutants were identified using SGAtools (Wagih et al., 2013; http://sgatools.ccbr.utoronto.ca/). To confirm mutant sensitivity, mutants identified with SGAtools were grown to stationary phase in $2 \mathrm{ml}$ of YPD on a shaking incubator at $30{ }^{\circ} \mathrm{C}$ for two days and diluted 0 to $10^{-4} \times$ in YPD before spotting $15 \mu$ l aliquots onto G418 sulphate supplemented YPD agar. Volatile compounds were applied as above and sensitivity was assessed based on a comparison to growth in a no-volatile control. Mutants that showed less than a $10^{2} \times$ reduction in colony number were classified as insensitive, while those that showed a $10^{2}$ to $10^{3} \times$ reduction were classified as sensitive and mutants that showed a $10^{4} \times$ or greater reduction in 
colony number were classified as highly sensitive (see Figure 2.2). All mutants that were confirmed as sensitive to each volatile compound were subsequently screened for sensitivity to all four volatile compounds.

Candidate genetic pathways affected by compounds were inferred based on information from gene ontology searches using Funspec (Robinson et al., 2002; http://funspec.med.utoronto.ca/) and DAVID Functional Annotation Tool (Huang et al., 2009a; Huang et al., 2009b; https://david.ncifcrf.gov/summary.jsp). All ontology terms that were associated with more than one gene and enriched with $p \leq 0.10$ were reported.

\section{Follow-up to deletion arrays}

To test if the pathways inferred from ontology searches were involved in compound mode of action, secondary assays were performed. Due to high levels of within-group variability when yeast cells were exposed to volatile compounds, assays were performed by exposing yeast to the liquid phase of the volatile compounds. To determine a sub-inhibitory concentration to use for each compound, yeast cells were grown overnight in YPD and their concentration was adjusted to an $\mathrm{OD}_{600}$ of 0.75 to 0.80 . Cells were placed into $1.5 \mathrm{ml}$ epitubes in $200 \mu$ aliquots with $0.5 \%$ Tween 80 (to emulsify the compounds) before each compound was added. A dilution series of each compound was used to vary exposure concentrations. The epitubes were incubated at $30{ }^{\circ} \mathrm{C}$ for 3 hours before diluting and plating onto PDA. After two days incubation at $30{ }^{\circ} \mathrm{C}$, colonies were counted and the concentration where cell survival was approximately $80 \%$ of the no-compound control was used for all subsequent assays.

To expose S. cerevisiae to the volatile compounds in secondary assays, the following protocol was used except where noted. Strain S288C was grown overnight in YPD and then 
adjusted to an $\mathrm{OD}_{600}$ of between 0.75 and 0.80 before $200 \mu 1$ aliquots of cell suspension were placed into epitubes. Sub-inhibitory concentrations of each compound (1.5 $\mu 1$ 1-pentanol, $1.5 \mu 1$ 2-methyl-1-butanol, $0.95 \mu 1$ propionic acid, $0.1 \mu 1$ nonanal) were added to the cell suspensions and emulsified with $0.5 \%$ Tween 80 before incubating at $30{ }^{\circ} \mathrm{C}$ for three hours.

\section{Oxidative stress assay}

To assess if the volatile compounds caused an increase in oxidative stress, cells were stained with 2',7'-dichlorofluorescein diacetate (DCFDA). Cells were incubated with compounds and with $10 \mu \mathrm{g} \mathrm{ml}^{-1}$ DCFDA dissolved in DMSO (Madeo et al., 1999). As a positive control, cells were incubated with $5 \mathrm{mM}$ hydrogen peroxide. To ensure that levels of oxidative stress were considered only in the live cell population, propidium iodide was added to a final concentration of $4 \mu \mathrm{g} \mathrm{ml}^{-1}$ and only propidium iodide negative cells were examined for DCFDA fluorescence. Cells were analysed using a BD Accuri C6 flow cytometer, with DCFDA fluorescence analysed on the FL1 channel (533/30 nm) and propidium iodide fluorescence analysed on the FL2 channel $(585 / 40 \mathrm{~nm})$. Three independent experiments were performed, each with 3 replicates and 10,000 cells counted per replicate. For statistical analysis, the average values of the replicates for each experiment were reported.

\section{Endocytosis assay}

To assess the effect of each compound on endocytosis, a lucifer yellow assay was used (Dulic et al., 1991; Wiederkehr et al., 2001; Motizuki et al., 2008). Cells were grown overnight in YPD and adjusted to an OD of between 0.75 and 0.80 before $100 \mu 1$ of the cell suspension was mixed with $100 \mu \mathrm{l}$ of incubation buffer ( $12.5 \mathrm{mM}$ sodium phosphate, $2.5 \mathrm{mM}$ sodium fluoride) in a $1.5 \mathrm{ml}$ epitube and a sub-inhibitory concentration of each compound was added separately as 
described above. As a positive control, $2.5 \mathrm{mM}$ sodium azide was added to the incubation buffer. Epitubes were incubated at $30^{\circ} \mathrm{C}$ for 30 minutes, after which lucifer yellow was added to the cell/buffer mixture to a final concentration of $4 \mathrm{mg} \mathrm{ml}^{-1}$. Cells were incubated at $30^{\circ} \mathrm{C}$ for an additional 3 hours before washing three times and then resuspending in incubation buffer. Fluorescence was measured using the FL1 channel of a BD Accuri C6 flow cytometer. Three independent experiments were performed, each with 3 replicates and a minimum of 10,000 cells counted per replicate. For statistical analysis, the average value across the replicates for each experiment was reported. To photograph lucifer yellow uptake, an aliquot of the no-compound control and the propionic acid-treated cells were photographed under a Zeiss Axioplan 2 imaging microscope with an AxioCam HRm camera.

\section{Cell cycle progression assay}

To assess the effect of each compound on cell cycle progression, propidium iodide DNA staining was used (Wu et al., 2011). Yeast were exposed to compounds for 3 hours and then pelleted by centrifugation and fixed by resuspending in $500 \mu 1$ of $70 \%$ ethanol. Cells were then incubated at room temperature for 2.5 hours and resuspended in $500 \mu 1$ PBS for 5 to 10 minutes before pelleting and resuspending in $100 \mu 1$ PBS with $1 \mathrm{mg} / \mathrm{ml}$ RNase A. Cells were incubated overnight at $37^{\circ} \mathrm{C}$ and then pelleted and resuspended in $100 \mu 1$ PBS with $50 \mu \mathrm{g} / \mathrm{ml}$ propidium iodide before incubating in the dark at $37{ }^{\circ} \mathrm{C}$ for 1 hour. Propidium iodide staining was analysed using the FL2 channel of a BD Accuri C6 flow cytometer and the percentage of cells in each phase of the cell cycle was calculated using ModFit LT. Three independent experiments were conducted, each with three replicates and 10,000 cells counted per replicate. 


\section{Permeability assay}

To assess if the compounds increased membrane permeability in yeast, we analysed the proportion of cells that excluded propidium iodide as a marker of an intact membrane (Davey and Hexley, 2010). Cells were exposed to compounds before $50 \mu \mathrm{g} / \mathrm{ml}$ propidium iodide was added. Cells were analysed on a BD Accuri C6 flow cytometer and the percentage of cells excluding propidium iodide was calculated based on an FL2 channel threshold of 1500. This was previously determined to be a conservative minimum fluorescence value for a dead (propidium iodide-positive) cell population. The experiment was performed independently three times, each with three replicates per condition and 10,000 cells analysed per replicate.

To determine if transient membrane permeability occurred, cells were incubated with compounds, using $20 \%$ ethanol as a positive control. Cells were examined after 0, 30, 60, and 150 minutes of compound exposure by adding $50 \mu \mathrm{g} / \mathrm{ml}$ propidium iodide and incubating for an additional 5 minutes before using flow cytometry to determine the percentage of the population that was propidium-iodide positive, as above.

\section{Cellular respiration assay}

To assess the effect of each compound on cellular respiration, the reduction of 3-(4,5Dimethyl-2-thiazolyl)-2,5-diphenyl-2H-tetrazolium bromide (MTT) was monitored (Stowe et al., 1995; Sánchez and Königsberg, 2006). Yeast cells were grown overnight in YPD and then washed twice with approximately $30 \mathrm{ml}$ of sterile water before starving for between 8 and 14 hours in approximately $30 \mathrm{ml}$ of sterile water. Cells were then resuspended to log phase density $\left(\mathrm{OD}_{600}\right.$ between 0.75 and 0.8$)$ in YPD and $150 \mu 1$ of cell suspension was placed into a microtiter plate with $15 \mu 12.89 \mathrm{mM}$ MTT, $10 \mu 10.19 \mathrm{mM}$ phenazine methosulfate, and $25 \mu 110 \%$ Triton 
$\mathrm{X}-100$, before adding compounds as explained above. The microtiter plate was sealed with parafilm and placed into a BioTek Instruments Cytation 5 microtiter plate reader set to $30{ }^{\circ} \mathrm{C}$ with continuous shaking. $\mathrm{A}_{570}$ and $\mathrm{A}_{660}$ were measured every 5 minutes for 9 hours. Wells containing control conditions were placed between each compound to ensure that the potential volatilization of the compounds within the plate did not affect the results. Additionally, no-cell controls were included with each compound. Each experiment was performed independently three times, with 5 replicates per experiment. MTT reduction for yeast exposed to each

compound was calculated at each time point as $\frac{A_{570} \text { exp.- } A_{570} \text { cont. }}{A_{660} \text { exp. }}$ where $A_{570}$ exp. and $A_{660}$ exp. are the absorbances of the cell suspension, and $\mathrm{A}_{570}$ cont. is the absorbance of the cell-free suspension.

\section{Gene expression assay}

Three strains of yeast cells stably expressing GFP (PIN4-GFP, PSK2-GFP, and TPK2GFP) were grown separately overnight in YPD and adjusted to log phase before $600 \mu 1$ of each were placed separate into $1.5 \mathrm{ml}$ epitubes with $0.5 \%$ Tween 80 . Sub-inhibitory concentrations of compounds were added to the epitubes ( $4.5 \mu 1$ 2-methyl-1-butanol, $4.5 \mu 1$ 1-pentanol, $0.3 \mu 1$ nonanal, and $2.85 \mu 1$ propionic acid) and $3 \mu 1$ of $35 \mu \mathrm{g} \mathrm{ml}^{-1}$ cycloheximide in ethanol was added as a positive control. Cells were incubated in epitubes for 30 minutes before transferring to separate wells of an 8 -well plate. GFP was photobleached for 20 minutes by gently agitating the plate without the lid approximately $2 \mathrm{~cm}$ from a 13-watt, 1050 lumen daylight-spectrum LED spotlight. Because some of the cell/compound mixture evaporated during this time, $100 \mu 1$ of autoclaved distilled water was added back to each well and the cells were transferred back to epitubes with additional volatile compound (1.5 $\mu 1$ 2-methyl-1-butanol, $1.5 \mu 1$ 1-pentanol, $0.1 \mu 1$ 
nonanal, and $0.95 \mu 1$ propionic acid). Cells were incubated in the dark for an additional 2 hours before adding $50 \mu \mathrm{g} \mathrm{ml}^{-1}$ of the vital stain propidium iodide. Cells were incubated in the dark for 5 minutes and then analysed on a BD Accuri C6 flow cytometer. The fluorescence of GFP was analysed on the FL1 channel and the FL2 channel was used to exclude cells staining with propidium iodide from the analysis.

\section{Statistical analysis}

For each independent experiment, replicates were averaged and the mean values were used for statistical analysis. Statistical analyses were conducted in R. For all assays, a one-way ANOVA was conducted to test for an effect of compound treatment on phenotype. Pairwise comparisons between the control and each condition were conducted using a Tukey's HSD posthoc test and Levene's test was used to confirm homogeneity of within-group variance. For cell cycle analysis, a separate one-way ANOVA was conducted for each phase of the cell cycle $\left(\mathrm{G}_{1}\right.$, $\mathrm{S}$, and $\mathrm{G}_{2}$ ) and for the MTT assay, a one-way ANOVA was conducted on the MTT reduction score at 9 hours.

\section{Results}

\section{Mutant sensitivity to volatile compounds}

We previously identified four volatile compounds that were inhibitory to $P$. destructans: 1-pentanol, propionic acid, 2-methyl-1-butanol, and isobutyl alcohol (Micalizzi et al., 2017). Due to the high concentration of isobutyl alcohol required to inhibit yeast, we instead examined the mode of action of nonanal, which also inhibits $P$. destructans (Cornelison et al., 2014a). To examine the antifungal mode of action of these volatiles, we exposed a yeast single-gene deletion array to sub-inhibitory concentrations of each compound. We generated a set of sensitive 
mutants for each compound and then compiled the sets to screen all sensitive mutants against all compounds. The sensitivity of each mutant to each compound was classified based on drop-out assays, as shown in Figure 2.2, and the sensitivity classification of each mutant to each compound is shown in Figure 2.3.

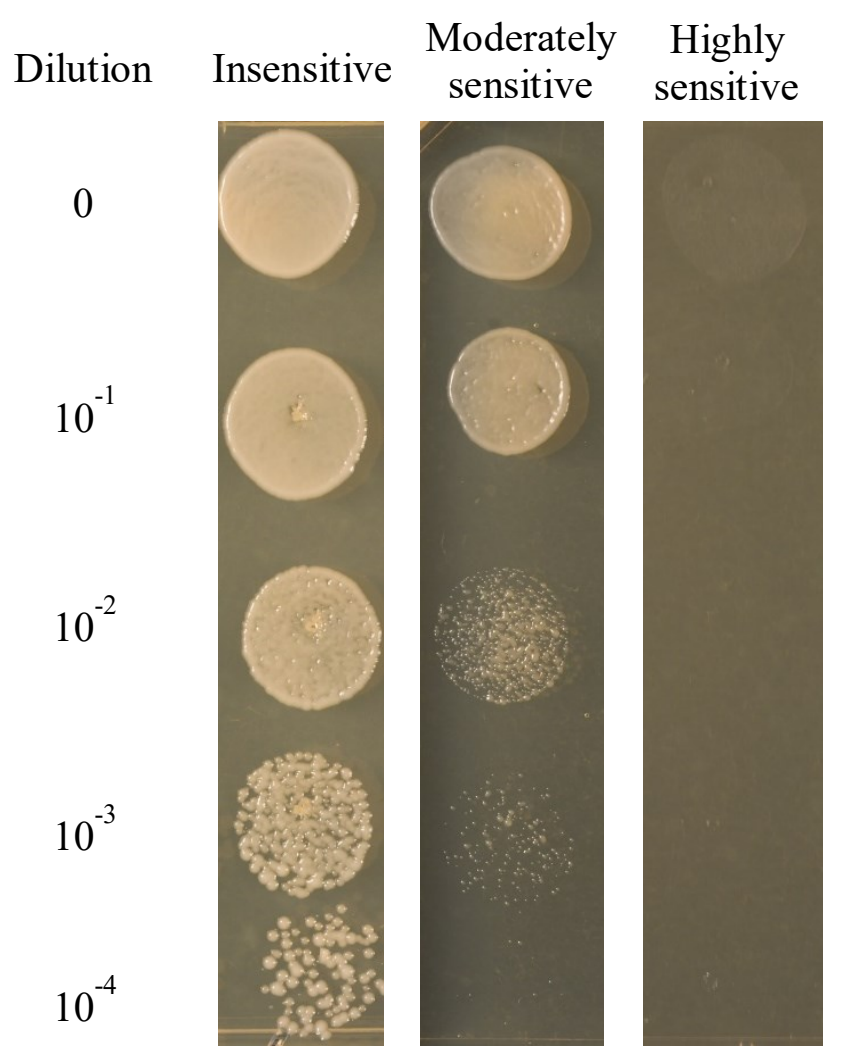

Figure 2.2. Images showing the classifications of sensitivity in yeast mutants exposed to volatile compounds. Yeast were grown to stationary phase and then serially diluted between 0 and $10^{4}$-fold before exposure to the volatile compounds. Mutants that were sensitive between $10^{-2}$ and $10^{-3} \times$ stationary phase cell density were classified as moderately sensitive and mutants sensitive at $\geq 10^{-1} \times$ stationary phase cell density were classified as highly sensitive. 


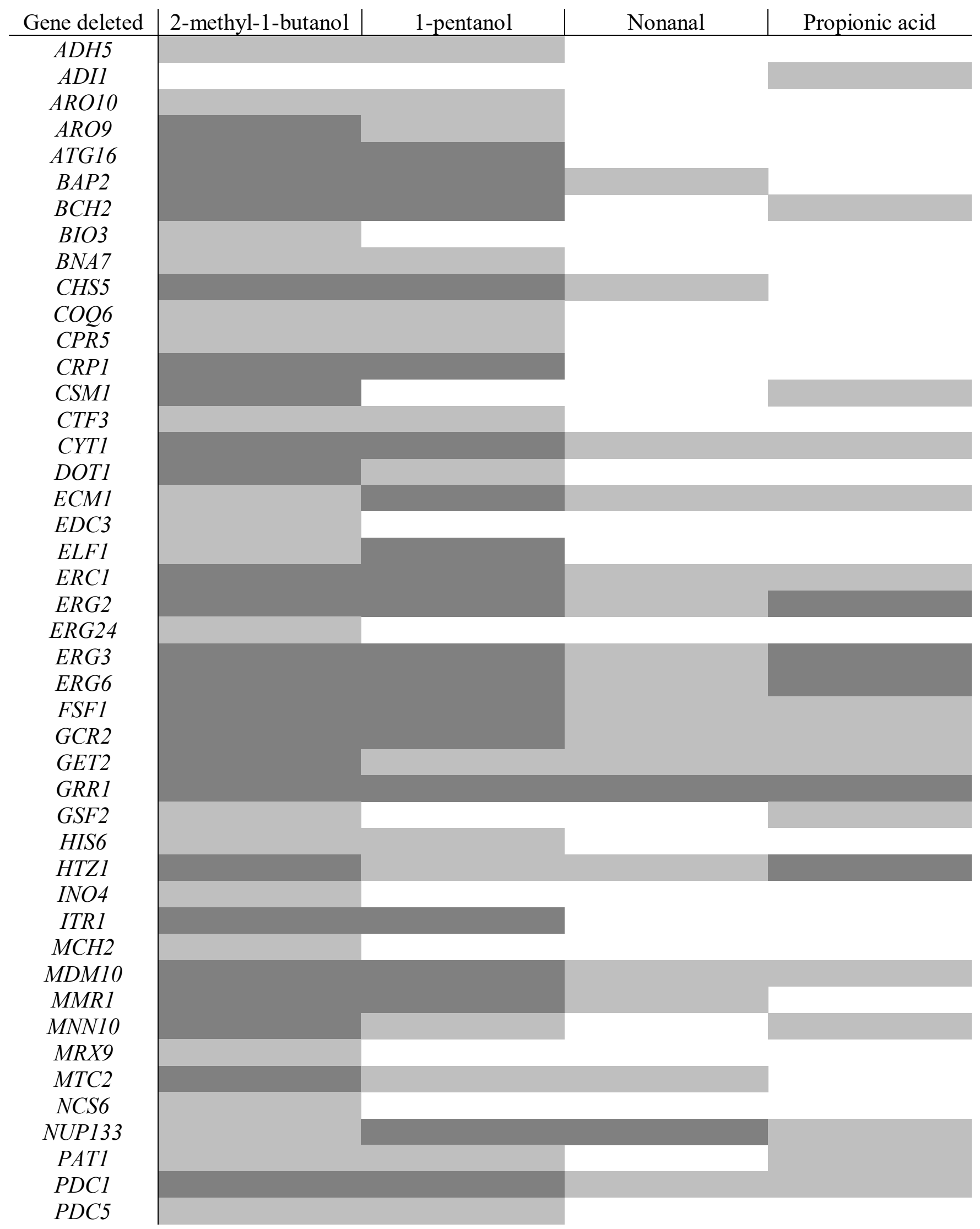




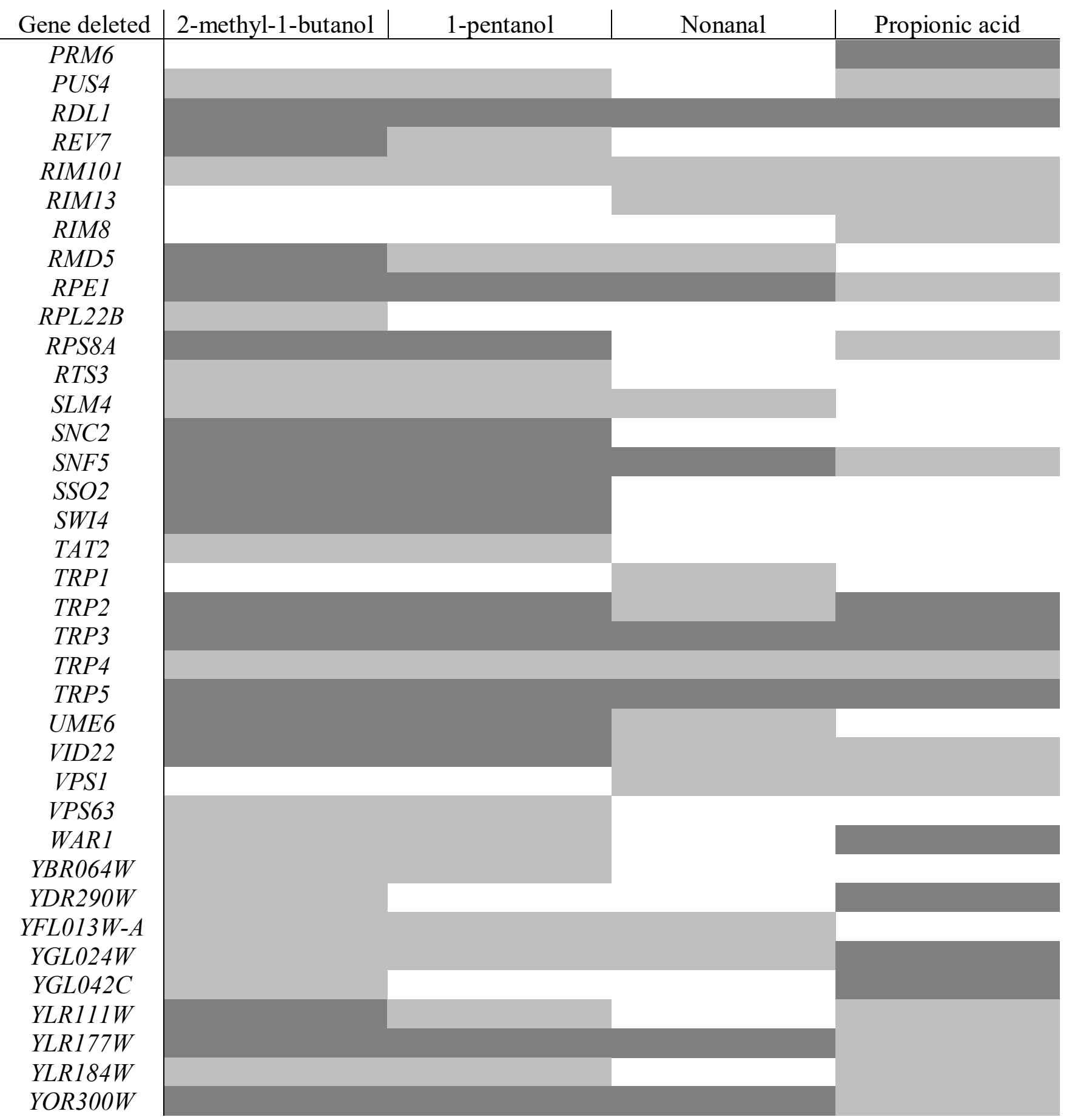

Figure 2.3. Sensitivity of single gene mutants of $\boldsymbol{S}$. cerevisiae to four volatile compounds.

Mutant strains were grown to stationary phase over two days and serially diluted in YPD before plating and exposing to sub-inhibitory concentrations of volatiles. White shading indicates insensitive mutants (not sensitive or sensitive at $<10^{-3} \times$ stationary phase cell density), light grey shading indicates moderately sensitive mutants (sensitive between $10^{-1}$ and $10^{-3} \times$ stationary phase cell density), and dark grey shading indicates highly sensitive mutants (sensitive at $\geq 10^{-1}$ $\times$ stationary phase cell density). 
Generally, there was a high degree of overlap between yeast mutant sensitivities to each compound. Of the 82 mutants tested, 42 were at least moderately sensitive to three or more of the compounds. The groups of mutants that were sensitive to 2-methyl-1-butanol and 1-pentanol were very similar. Every mutant that was sensitive to 1-pentanol was also sensitive to 2-methyl1-butanol; however, 12 mutants were sensitive to 2-methyl-1-butanol but not 1-pentanol. When comparing the highly sensitive mutants for both compounds, 31 out of 44 were highly sensitive to both compounds, with 10 highly sensitive only to 2-methyl-1-butanol and three highly sensitive only to 1-pentanol.

Nearly all the mutants that were sensitive to nonanal were also sensitive to the fusel alcohols 1-pentanol and 2-methyl-1-butanol; however, the fusel alcohols appeared to have additional mechanisms of action not shared with nonanal. Thirty three of 41 mutants highly sensitive to 2-methyl-1-butanol and 25 of 34 mutants highly sensitive to 1-pentanol were not highly sensitive to nonanal. Additionally, out of the 14 mutants highly sensitive to propionic acid, only four were sensitive to nonanal, while five were not highly sensitive to any other compounds.

To understand the pathways that these compounds act in, we conducted gene ontology searches of the deleted genes from highly sensitive mutants using DAVID functional analysis and Funspec. The enriched pathways for each compound are shown in Figure 2.4. 


\begin{tabular}{|c|c|c|c|c|}
\hline & $\begin{array}{l}\text { 2-methyl-1- } \\
\text { butanol }\end{array}$ & 1-pentanol & Nonanal & $\begin{array}{l}\text { Propionic } \\
\text { acid }\end{array}$ \\
\hline \multicolumn{5}{|l|}{ Biological Processes } \\
\hline \multicolumn{5}{|l|}{$\begin{array}{l}\text { Aromatic amino acid family } \\
\text { biosynthetic process }\end{array}$} \\
\hline \multicolumn{5}{|l|}{ Biosynthetic process } \\
\hline \multicolumn{5}{|l|}{$\begin{array}{l}\text { Carbohydrate metabolic } \\
\text { process }\end{array}$} \\
\hline \multicolumn{5}{|l|}{$\begin{array}{l}\text { Cellular amino acid } \\
\text { biosynthetic process }\end{array}$} \\
\hline \multicolumn{5}{|l|}{ Chromatin remodeling } \\
\hline \multicolumn{5}{|l|}{$\begin{array}{l}\text { Ergosterol biosynthetic } \\
\text { process }\end{array}$} \\
\hline \multicolumn{5}{|l|}{$\begin{array}{l}\text { Golgi to plasma membrane } \\
\text { transport }\end{array}$} \\
\hline \multicolumn{5}{|l|}{ Lipid biosynthetic process } \\
\hline \multicolumn{5}{|l|}{ Lipid metabolic process } \\
\hline \multicolumn{5}{|l|}{ Metabolic process } \\
\hline \multicolumn{5}{|l|}{ Mitochondrial inheritance } \\
\hline \multicolumn{5}{|l|}{$\begin{array}{l}\text { Regulation of transcription } \\
\text { (DNA-templated) }\end{array}$} \\
\hline \multicolumn{5}{|l|}{ Steroid biosynthetic process } \\
\hline \multicolumn{5}{|l|}{ Steroid metabolic process } \\
\hline \multicolumn{5}{|l|}{ Sterol biosynthetic process } \\
\hline \multicolumn{5}{|l|}{ Transport } \\
\hline \multicolumn{5}{|l|}{ Tryptophan biosynthesis } \\
\hline \multicolumn{5}{|l|}{$\begin{array}{l}\text { Tryptophan metabolic } \\
\text { process }\end{array}$} \\
\hline \multicolumn{5}{|l|}{ Vesicle fusion } \\
\hline \multicolumn{5}{|l|}{ Molecular Function } \\
\hline \multicolumn{5}{|l|}{$\begin{array}{l}\text { Anthranilate synthase } \\
\text { activity }\end{array}$} \\
\hline \multicolumn{5}{|l|}{ Catalytic activity } \\
\hline \multicolumn{5}{|l|}{ Lyase activity } \\
\hline \multicolumn{5}{|l|}{$\begin{array}{l}\text { RNA polymerase II core } \\
\text { promoter proximal region } \\
\text { sequence-specific DNA } \\
\text { binding }\end{array}$} \\
\hline SNAP receptor activity & & & & \\
\hline
\end{tabular}




\begin{tabular}{|l|l|l|l|l|}
\multicolumn{2}{l}{$\begin{array}{l}\text { 2-methyl-1- } \\
\text { butanol }\end{array}$} & 1-pentanol & Nonanal & $\begin{array}{l}\text { Propionic } \\
\text { acid }\end{array}$ \\
\hline Cellular Compartment & & & & \\
\hline $\begin{array}{l}\text { Anthranilate synthase } \\
\text { complex }\end{array}$ & & & & \\
\hline Cytosol & & & & \\
\hline Endoplasmic reticulum & & & & \\
\hline Exomer complex & & & & \\
\hline $\begin{array}{l}\text { Integral component of } \\
\text { membrane }\end{array}$ & & & & \\
\hline Membrane & & & & \\
\hline $\begin{array}{l}\text { Mitochondrial outer } \\
\text { membrane }\end{array}$ & & & & \\
\hline Nuclear chromatin & & & & \\
\hline KEGG Pathways & & & & \\
\hline Biosynthesis of amino acids & & & & \\
\hline Biosynthesis of antibiotics & & & & \\
\hline $\begin{array}{l}\text { Biosynthesis of secondary } \\
\text { metabolites }\end{array}$ & & & & \\
\hline Metabolic pathways & & & & \\
\hline $\begin{array}{l}\text { Phenylalanine, tyrosine, and } \\
\text { tryptophan biosynthesis }\end{array}$ & & & & \\
\hline Steroid biosynthesis & & & & \\
\hline
\end{tabular}

Figure 2.4. Gene ontology terms and pathways affected by exposure to volatile compounds. Boxes show terms that were significantly ( $p<0.05$, dark blue) and moderately significantly $(0.10 \geq p \geq 0.05$, light blue) enriched for highly sensitive mutants in DAVID functional analysis or Funspec gene ontology searches. For each compound, all enriched terms are shown that were associated with more than one gene and had a $p$-value $\leq 0.10$. White cells indicate that the pathway was not enriched for the specific compound.

Tryptophan and aromatic amino acid synthesis and metabolism was significantly enriched for all compounds. Similarly, anthranilate synthase, which catalyses an early step in tryptophan biosynthesis, was enriched for all compounds except nonanal. Steroid, sterol, and lipid biosynthesis was also significantly enriched for all compounds except for nonanal. 
The most overlap in function was between 2-methyl-1-butanol and 1-pentanol, which were both enriched in terms that may be associated with vesicular trafficking (Golgi to plasma membrane transport biological process, exosome complex and membrane cellular compartments, and SNAP receptor activity molecular function [involved in vesicle fusion]). The mitochondrial outer membrane cellular compartment was also significantly enriched for 2-methyl-1-butanol and 1-pentanol. The functions of the two compounds did not completely overlap; however, and 2-methyl-1-butanol was uniquely enriched in terms that could relate to transcriptional activation (nuclear chromatin, chromatin remodeling, and RNA polymerase II core promoter proximal region sequence-specific DNA binding), while 1-pentanol was uniquely enriched in terms related to transport (transport, vesicle fusion, and integral component of plasma membrane cell compartment).

The processes enriched for propionic acid-sensitive mutants overlapped heavily with those of 1-pentanol and 2-methyl-1-butanol. The only enriched terms not shared with both 2methyl-1-butanol and amyl-alcohol were lipid metabolic process, which was unique, and endoplasmic reticulum cellular compartment, which was also enriched for 2-methyl-1-butanol but not 1-pentanol. Nonanal had the fewest terms enriched and was uniquely enriched in the cytosol cellular compartment, catalytic activity molecular function, and carbohydrate metabolic activity biological process.

\section{Follow-up to gene ontology searches}

Because of the enrichment of the ontology term "mitochondrial outer membrane" in cells treated with 2-methyl-1-butanol and 1-pentanol, as well as literature suggesting that 2-methyl-1butanol and propionic acid can cause oxidative stress (Rezende et al., 2015; Yun and Lee, 2016), 
we assessed if any of the compounds caused an increase in oxidative stress using $2^{\prime}, 7^{\prime}$ -

dichlorofluorescein diacetate (DCFDA). DCFDA is a non-fluorescent and cell permeable dye that is oxidized to the fluorescent product 2'7'-dichlorofluorescein (DCF) in the presence of reactive oxygen species and generally retained in the cell. Fluorescence in the positive control (hydrogen peroxide) was over three-fold higher than any of the four volatile compounds tested and significantly different from the negative control (mean difference $(\mathrm{MD})=3.59, p=0.032$ ). In contrast, the fluorescence of cells treated with 2-methyl-1-butanol, 1-pentanol, propionic acid, or nonanal were not significantly different from the negative control (all $p$-values $>0.99$; Figure 2.5).

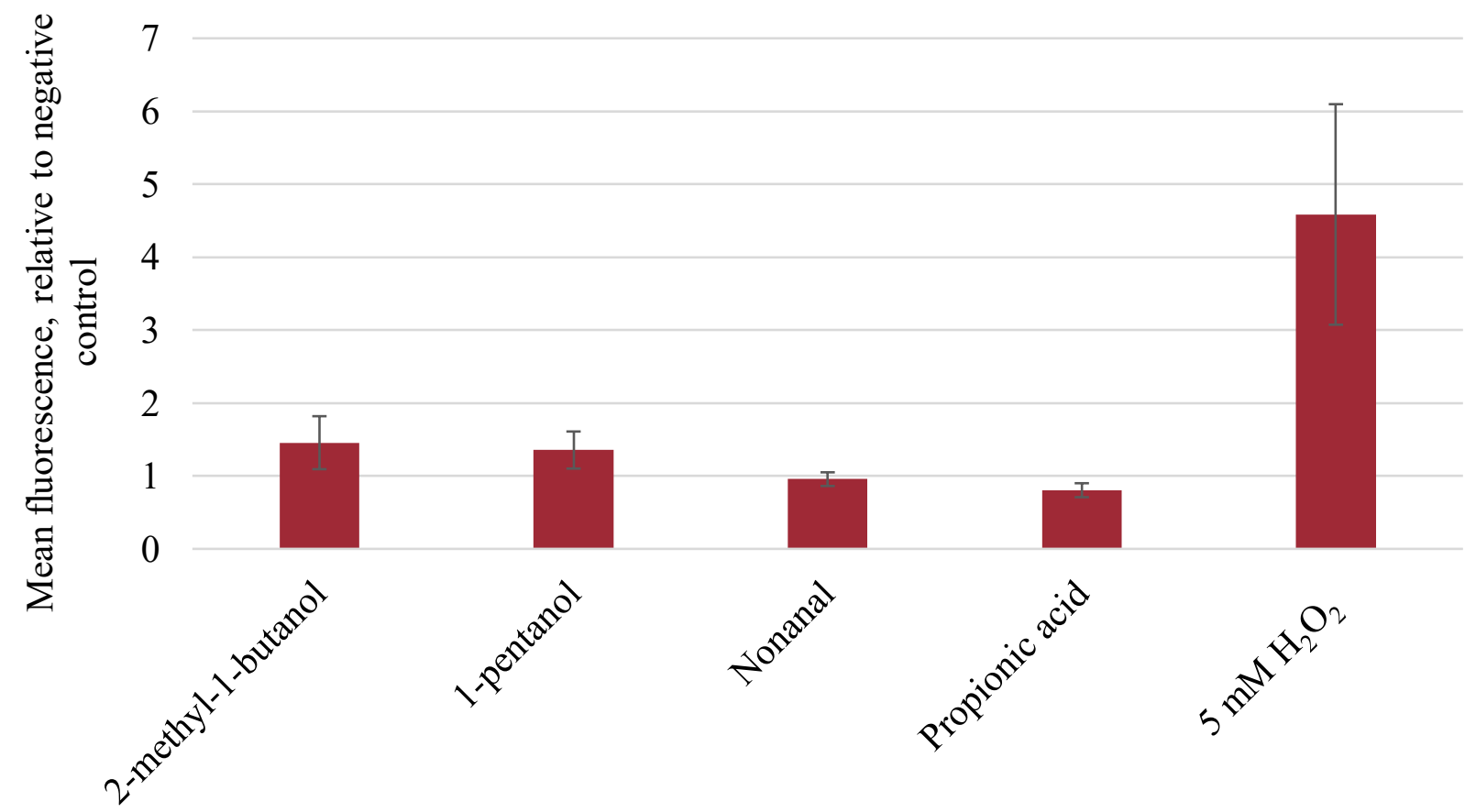

Figure 2.5. Levels of oxidative stress in yeast exposed to four volatile compounds. Graph shows mean fluorescence of live (i.e. not stained by propidium iodide) yeast cells in the presence of 2'7'-dichlorofluorescein diacetate after treatment with sub-inhibitory concentrations of 2methyl-1-butanol, 1-pentanol, nonanal, or propionic acid. Fluorescence is expressed relative to a no-treatment control and $5 \mathrm{mM}$ hydrogen peroxide was used as a positive control. Numbers are averages of three independent experiments, each with three replicates per experiment and 10,000 cells counted per replicate. Error bars represent standard error $(n=3)$. 
Because of the enrichment of gene ontology terms associated with vesicle trafficking and the plasma membrane, we assessed if any of the compounds affected endocytosis by monitoring the uptake of lucifer yellow, a hydrophilic fluorescent dye that enters cells through endocytosis. A one-way ANOVA revealed a significant effect of compound on lucifer yellow internalization $(F(5,12)=85.03, p<0.001)$. A post-hoc Tukey's HSD test showed that fluorescence in cells treated with propionic acid was significantly different than in the control $(\mathrm{MD}=4.54 ; p<0.001)$, but there were no significant differences between the control and any other condition (all $p$ values $>0.8$; Figure 2.6, Figure 2.7).

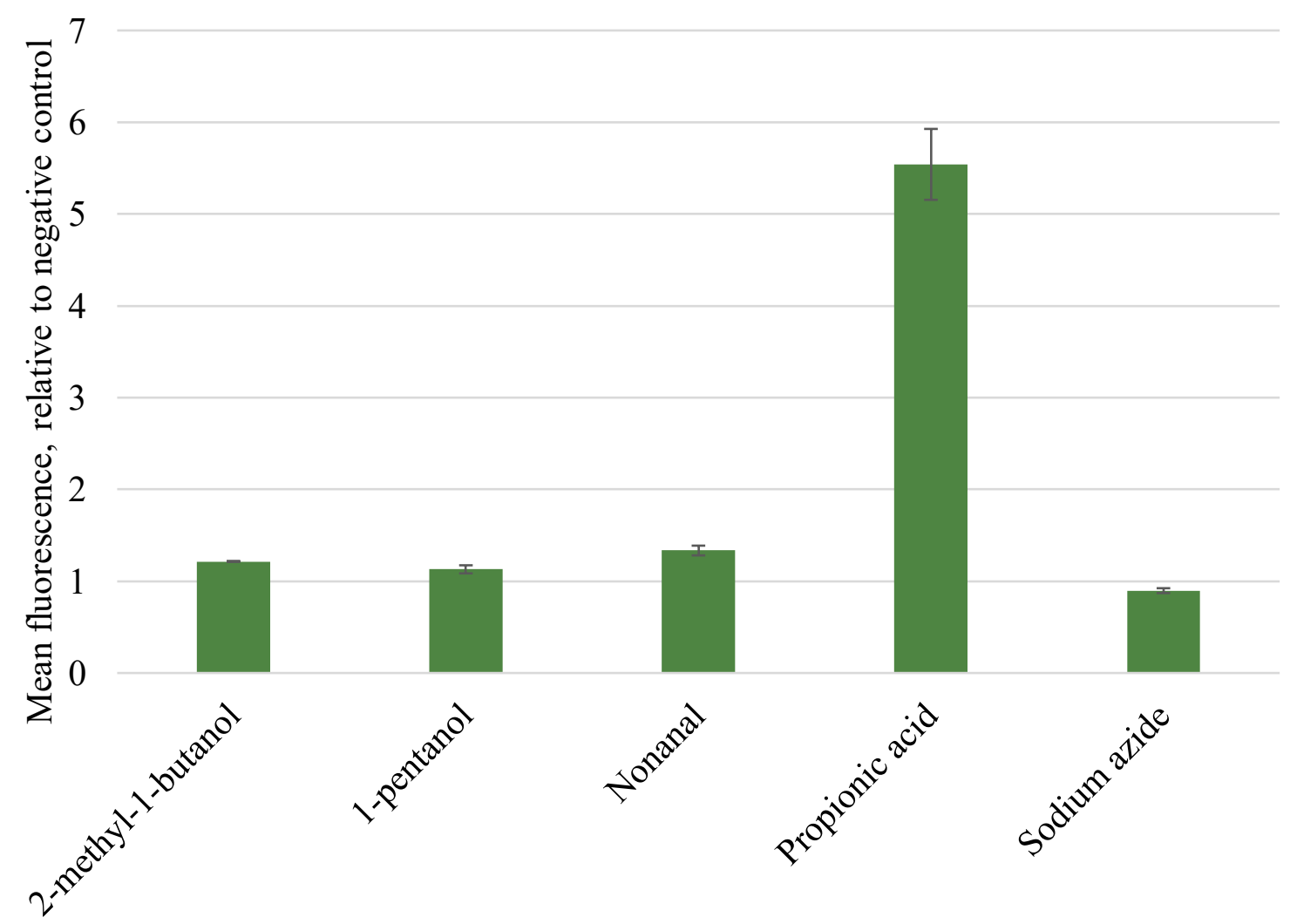

Figure 2.6. Lucifer yellow uptake in yeast cells exposed to compounds. Log-phase yeast cells were incubated for 30 minutes with a sub-inhibitory concentration of 2-methyl-1-butanol, 1pentanol, nonanal, or propionic acid before lucifer yellow was added and cells were incubated an additional 3 hours. Sodium azide interferes with endocytosis and was used as a positive control. Lucifer yellow uptake was quantified by flow cytometry. Numbers are averages of three independent experiments, each with three replicates per experiment and 10,000 cells analysed per replicate. Error bars show standard error $(n=3)$. 

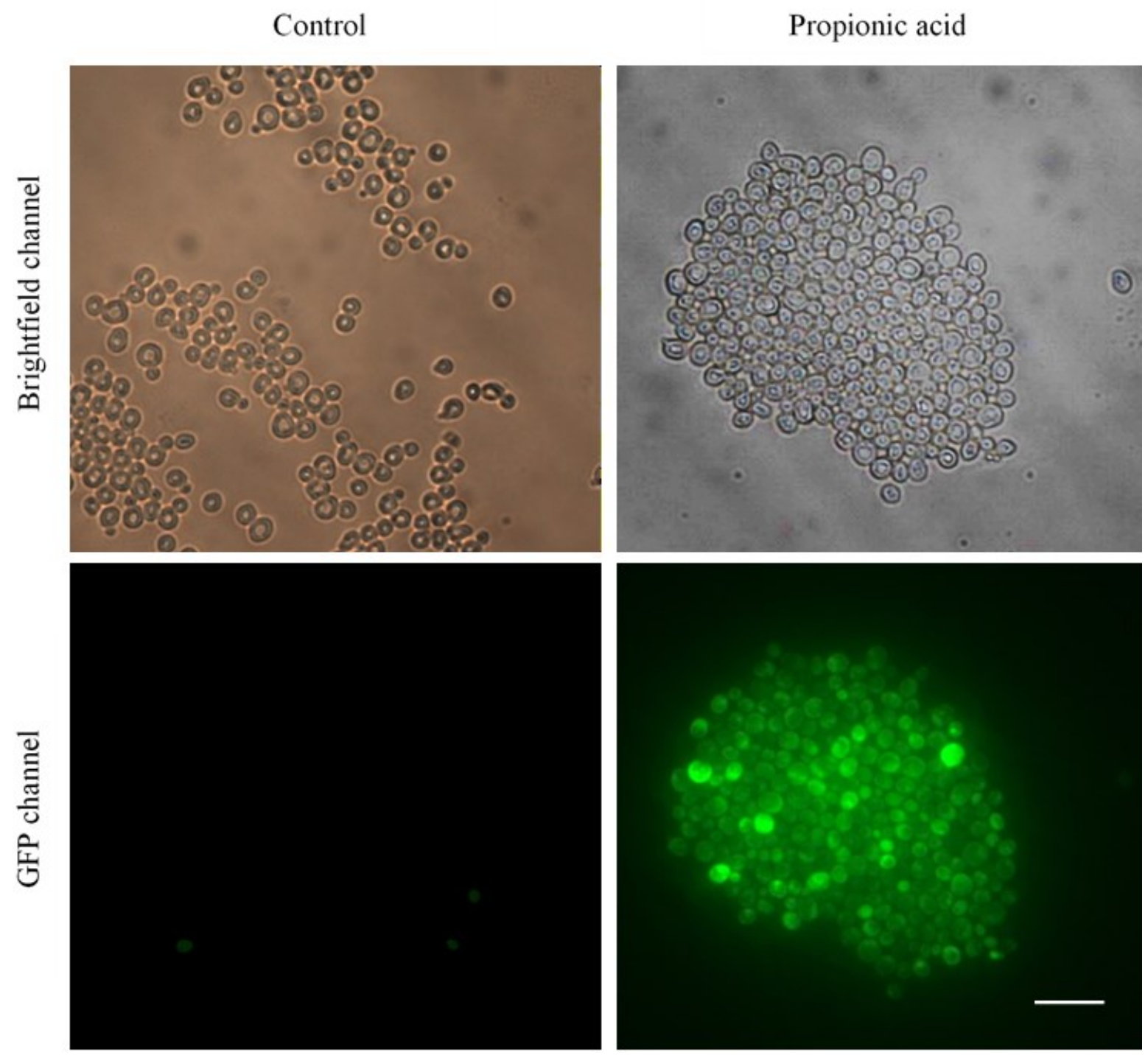

Figure 2.7. Micrographs showing lucifer yellow uptake in propionic acid-treated cells. Images show brightfield (top) and GFP (bottom) channels. Images contrast the uptake of lucifer yellow in clusters of yeast cells in a no-treatment (negative) control (left) compared to treatment with a sub-inhibitory concentration of propionic acid (right). White scale bar represents $25 \mu \mathrm{m}$.

Due to the enrichment of gene ontology terms related to chromatin and a high frequency of terms related to meiosis, mitosis, and cell cycle, we assessed if any of the compounds affect cell cycle progression by staining and measuring DNA content with propidium iodide and then calculating the percentage of cells in $\mathrm{G}_{1}, \mathrm{~S}$, and $\mathrm{G}_{2}$ phases. As shown in Figure 2.8, there was a significant effect of compound treatment on the distribution of $\mathrm{G}_{1}(F(4,10)=21.25 ; p<0.001)$ 
and $\mathrm{G}_{2}(F(4,10)=13.83 ; p<0.001)$, but not $\mathrm{S}(F(4,10)=0.97 ; p=0.47)$ phase populations. A post hoc Tukey's HSD test revealed that, compared to the control, the percentage of cells in $\mathrm{G}_{1}$ was significantly higher in yeast treated with 2-methyl-1-butanol $(\mathrm{MD}=23.56 ; p=0.001), 1$ pentanol $(\mathrm{MD}=26.64, p<0.001)$, and propionic acid $(\mathrm{MD}=25.98, p<0.001)$. The percentage of cells in $\mathrm{G}_{2}$ was significantly lower in yeast treated with 2-methyl-1-butanol $(\mathrm{MD}=-19.78 ; p=$ 0.004), 1-pentanol $(\mathrm{MD}=-22.21, p=0.002)$, and propionic acid $(\mathrm{MD}=-25.98, p=0.008)$.

There were no significant differences in the percentage of cells in S-phase $(p \geq 0.50$ for all pairwise comparisons).

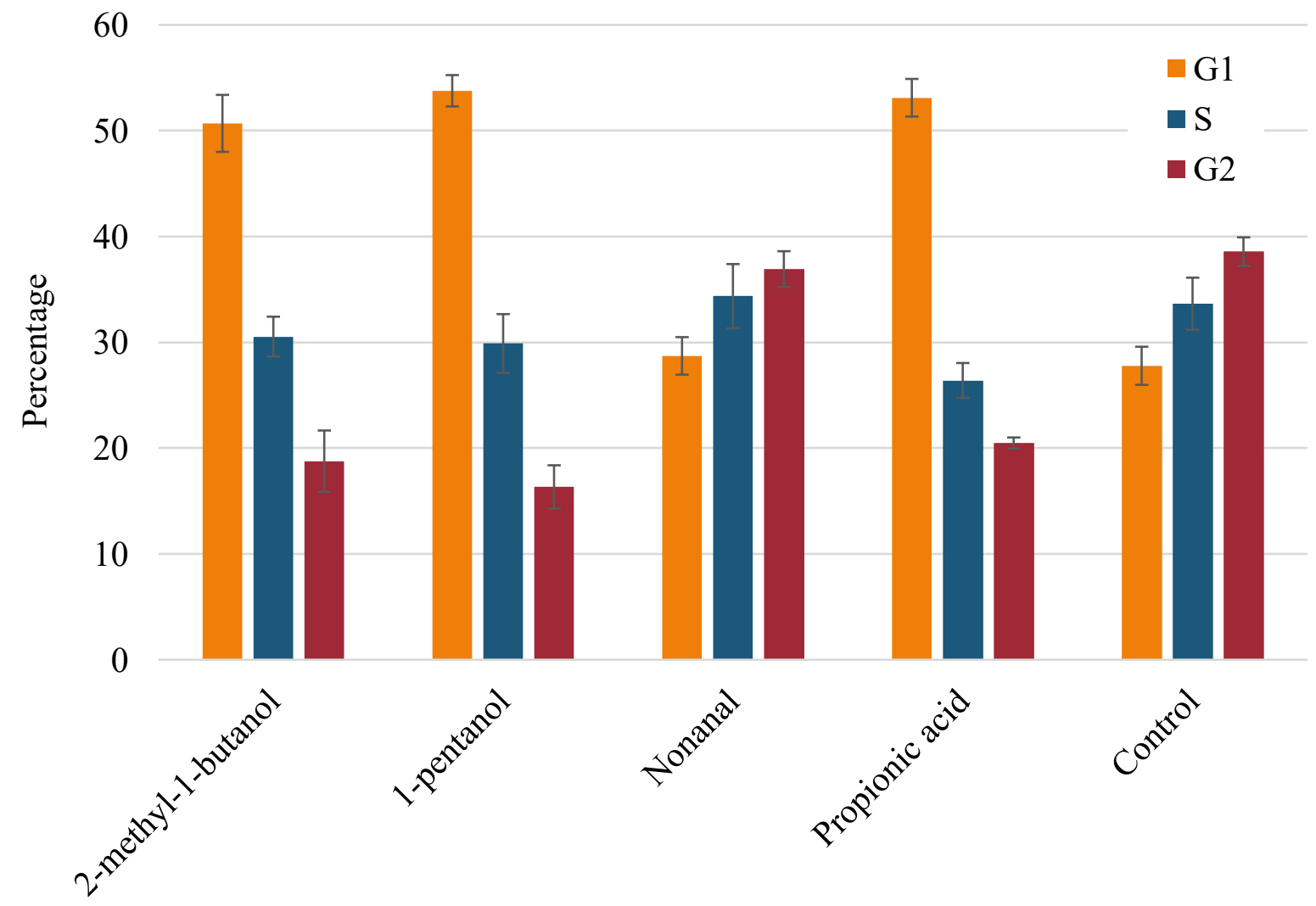

Figure 2.8. Cell cycle distributions in yeast treated with four volatile compounds. Cells were exposed to sub-inhibitory concentrations of compounds for 3 hours and then fixed before treating with RNase and staining with propidium iodide to assess DNA content. Populations were analysed using flow cytometry and the percentage of cells in each cell cycle phase was calculated in ModFit. The bar graph shows the average percentage of cells in each phase from three independent experiments, each with three replicates and 10,000 cells analysed per replicate. Error bars show standard error. 
Because of the enrichment in gene ontology terms associated with membranes (membrane cellular compartment and ergosterol, lipid, steroid, and sterol biosynthesis/metabolism) and the previous indications from the literature that all four tested compounds permeabilize cell membranes, we assessed if treatment with any of the compounds increased membrane permeability by using the exclusion of propidium iodide as a marker for intact membranes. After 3 hours of treatment with volatile compounds, there was no significant effect of compound on propidium iodide fluorescence $(F(4,10)=0.227, p=0.917)$ and no significant pairwise effect of any compound treatment on fluorescence ( $p>0.9$ for all comparisons; Figure 2.9). The average intracellular propidium iodide fluorescence was within $3 \%$ of the negative control uptake for all compounds tested and the greatest deviation from the control in any replicate was approximately $5 \%$. To determine if yeast cells adapt and reverse membrane permeability over the 3-hour incubation period (Davey and Hexley, 2011), permeability was assessed at different time points and $20 \%$ ethanol was used as a positive control (Figure 2.10). Permeability was relatively consistent throughout the incubation time and all conditions caused similar levels of permeability except for the $20 \%$ ethanol positive control, which caused permeability in approximately $10 \%$ more cells than the other conditions. Taken together, this suggests that at the concentrations used, these compounds cause negligible or very transient changes in $S$. cerevisiae membrane permeability. 


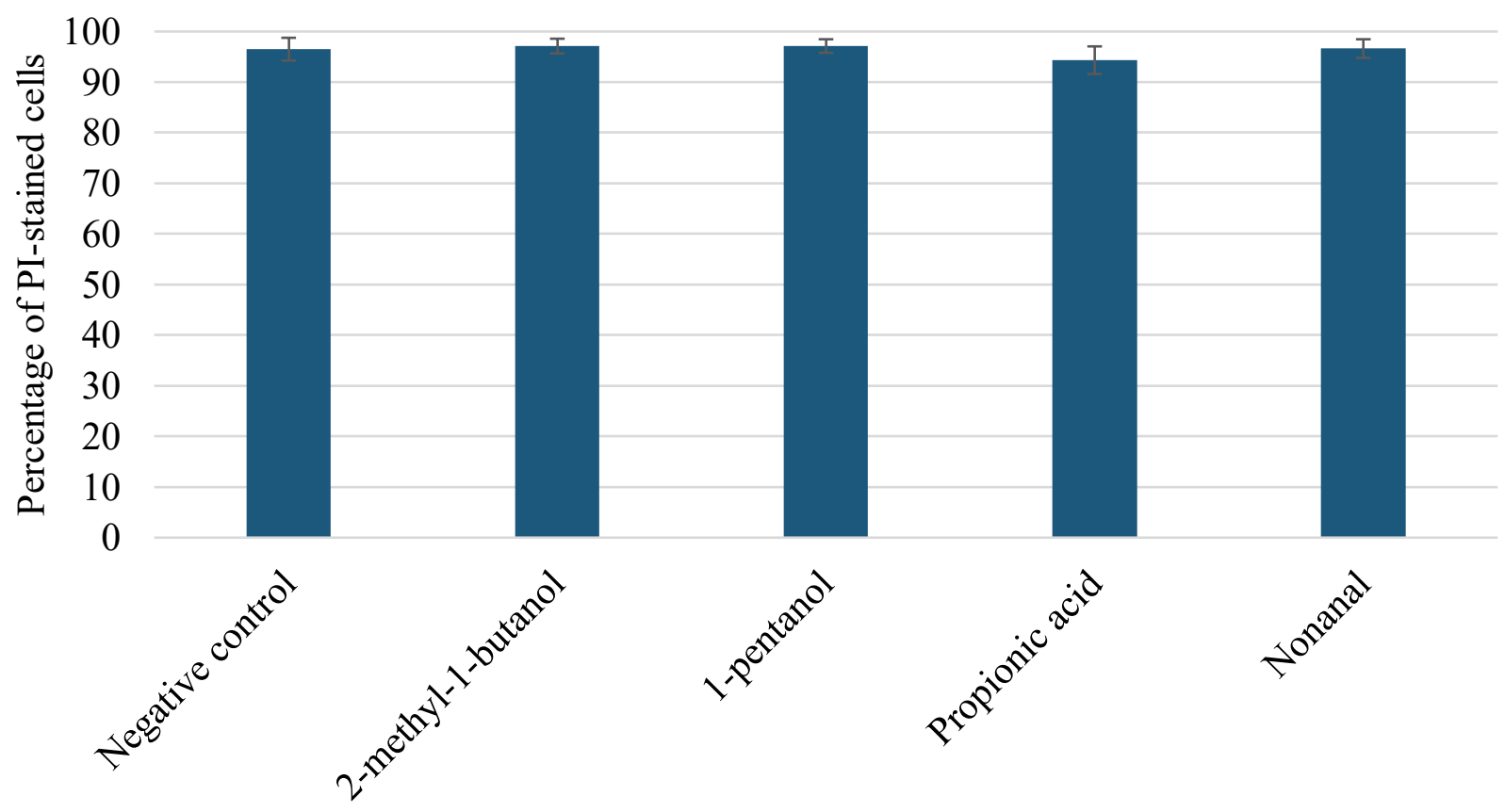

Figure 2.9. Test for yeast membrane permeabilization by compounds. Permeability was assessed by intracellular propidium iodide fluorescence. Yeast cells were exposed to a subinhibitory dose of each compound and incubated for 3 hours before the addition of propidium iodide. Flow cytometry was used to determine the percentage of the population that was propidium-iodide positive. Error bars show standard error from three replicates. 


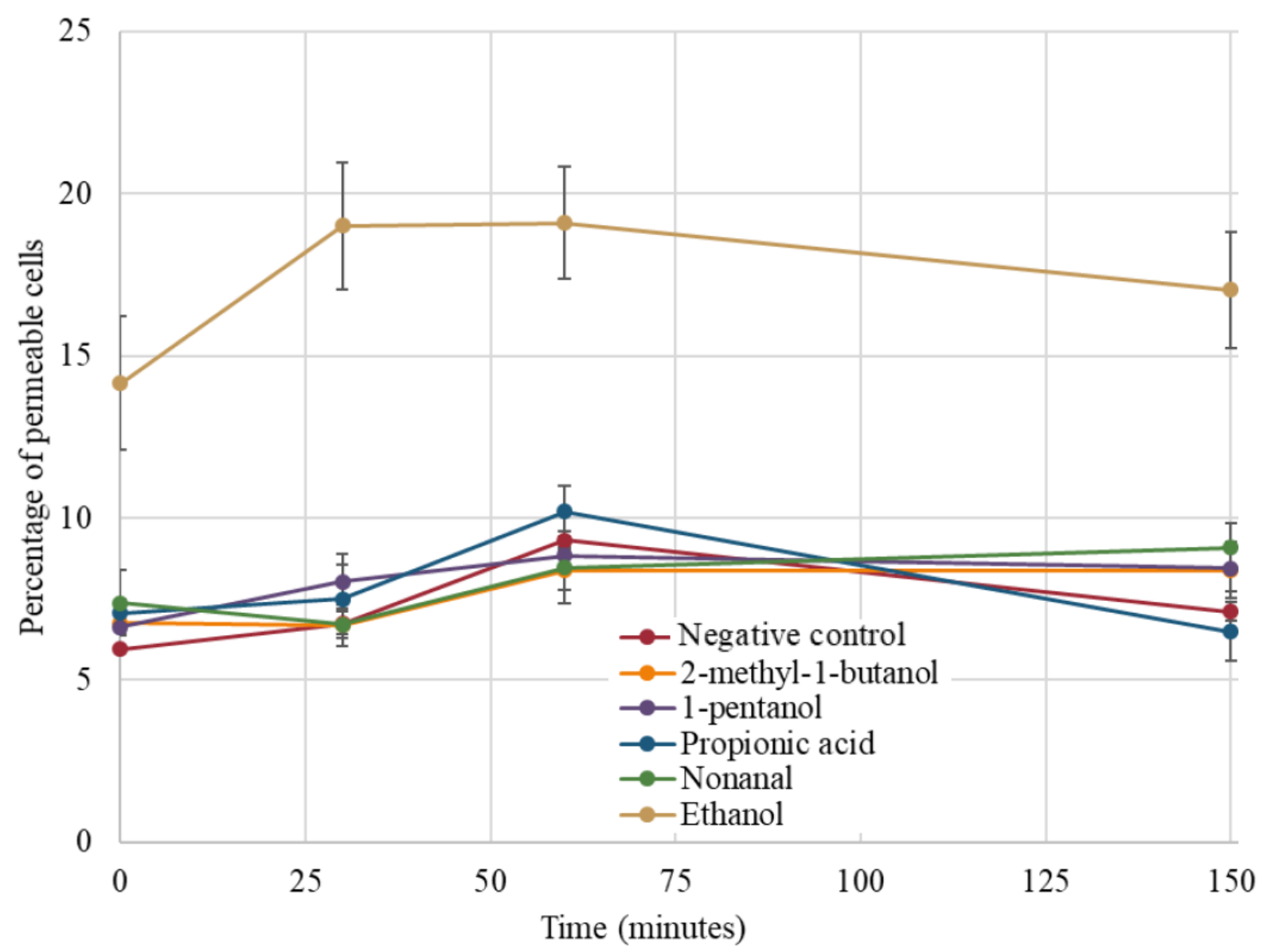

Figure 2.10. Test for yeast membrane permeabilization by compounds over time. Permeability was assessed by intracellular propidium iodide fluorescence. Yeast cells were exposed to a sub-inhibitory dose of each compound and incubated from 0 to 150 minutes before the addition of propidium iodide. After addition of propidium iodide, cells were incubated for an additional 5 minutes before using flow cytometry to determine the percentage of the population that was propidium-iodide positive. Ethanol (20\%) was used as a positive control, and a notreatment negative control was included. Error bars show standard error from three replicates.

Because of the enrichment of gene ontology terms related to metabolism and metabolic pathways, we assessed if any compounds affected cellular respiration by measuring the reduction of 3-(4,5-Dimethyl-2-thiazolyl)-2,5-diphenyl-2H-tetrazolium bromide (MTT; Stowe et al., 1995; Sánchez and Königsberg, 2006). MTT is reduced to a purple formazan salt by NADH-dependent reactions (Riss et al., 2016). A one-way ANOVA revealed that there was a significant effect of compound treatment on the reduction of MTT at 9 hours $(F(4,10)=4.451, p=0.025)$. A post- 
hoc Tukey HSD test showed that compared to the control, the endpoint reduction of MTT was significantly lower in cells treated with propionic acid $(\mathrm{MD}=-0.95 ; p=0.03)$ but there were no significant differences in cells treated with 2-methyl-1-butanol $(\mathrm{MD}=-0.32, p=0.73), 1$ pentanol $(\mathrm{MD}=-0.62, p=0.20)$, or nonanal $(\mathrm{MD}=-0.10, p=0.99)$.

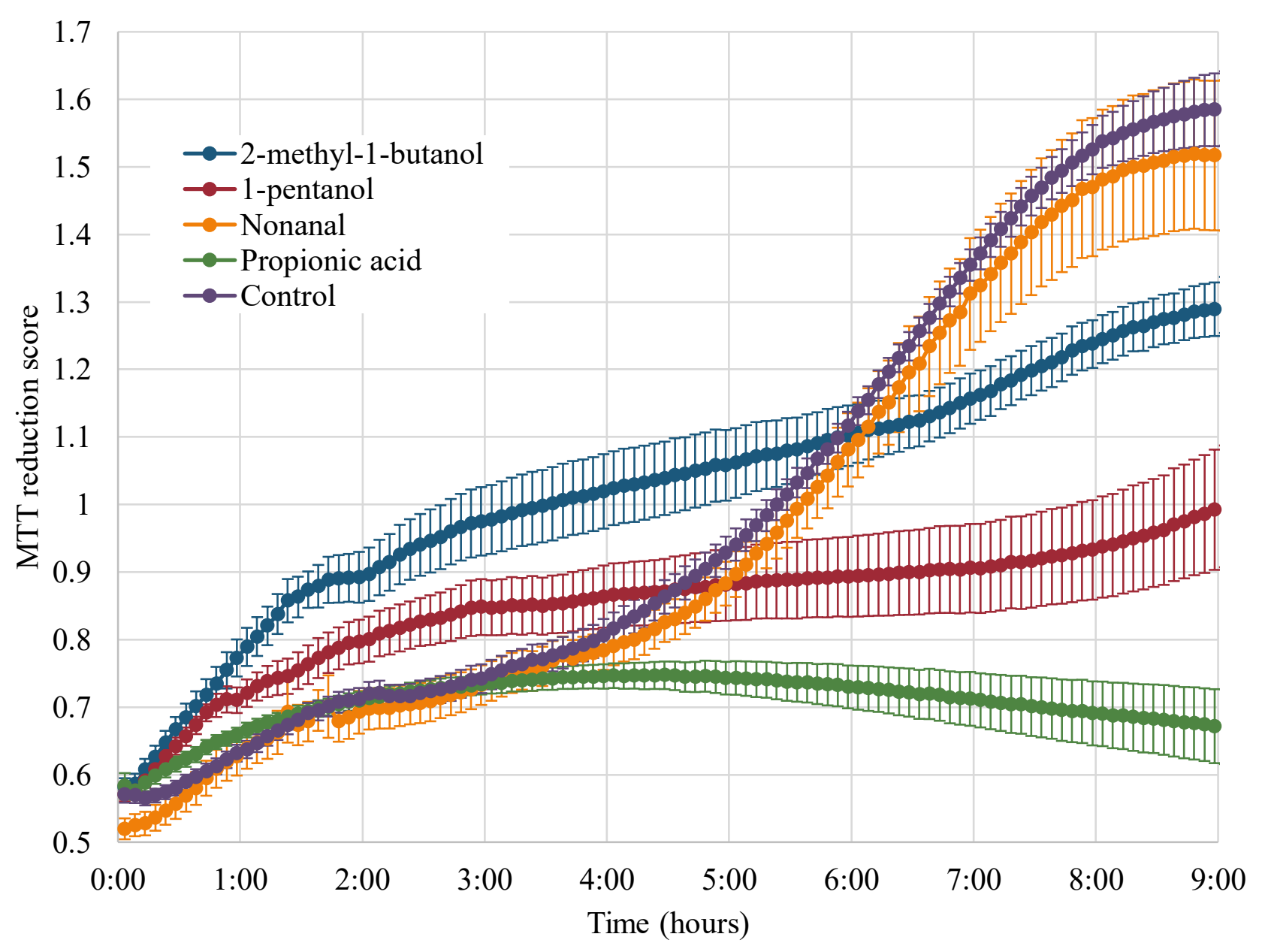

Figure 2.11. Effect of compounds on yeast reduction of MTT. Yeast were exposed to subinhibitory concentrations of nonanal, 1-pentanol, 2-methyl-1-butanol, and propionic acid, and the reduction of MTT was monitored spectrophotometrically for 9 hours. An MTT reduction score for yeast in the presence of each compound was calculated as $\frac{A_{570} \text { exp. }-A_{570} \text { cont. }}{A_{660} \exp .}$ where ' $\mathrm{A}_{570}$ exp.' and ' $\mathrm{A}_{660}$ exp.' are the absorbances of the cell suspension, and ' $\mathrm{A}_{570}$ cont.' is the absorbance of a cell-free blank. Numbers are average scores from 3 independent experiments, each with 5 replicates. Error bars show standard error $(n=3)$. 
Interestingly, the reduction of MTT by yeast exposed to 2-methyl-1-butanol, and to a lesser extent 1-pentanol, initially occurred at a greater rate than in the control, before decreasing to less than the control after approximately 2 hours (Figure 2.11). When strictly looking at the growth $\left(\mathrm{A}_{660}\right)$ of cells exposed to each compound, growth was increasingly delayed in 2-methyl1-butanol, 1-pentanol, and propionic acid, compared to the control (data not shown), which correlates with the MTT reduction score for each compound. Additionally, the reduction of MTT in the no-cell control with propionic acid was greatly reduced compared to all other no-cell conditions (data not shown), suggesting that propionic acid interferes with the non-enzymatic background reduction of MTT.

Because of enriched gene ontology terms associated with transcriptional regulation, RNA polymerase II, and chromatin, we assessed if exposure to the compounds affects yeast gene expression. We photobleached three yeast cell lines stably expressing GFP and measured the recovery of fluorescence in the presence of the compounds. As shown in Figure 2.12, the expression of GFP varied between the three cells; however compared to a no-treatment control, GFP fluorescence was consistently lower in cells treated with propionic acid, suggesting that propionic acid may reduce global gene expression. Interestingly, propionic acid caused the most dramatic decrease in expression of PIN4, which promotes $\mathrm{G}_{2}$ to $\mathrm{M}$ cell cycle progression and is negatively regulated during DNA damage checkpoints (Pike et al., 2004). 
A

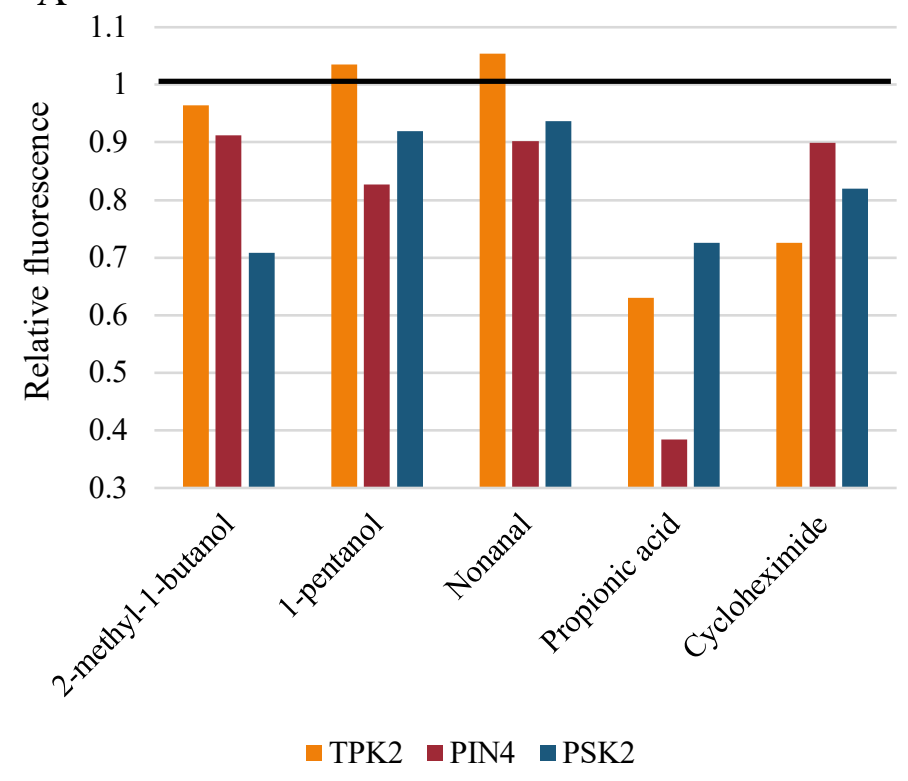

B

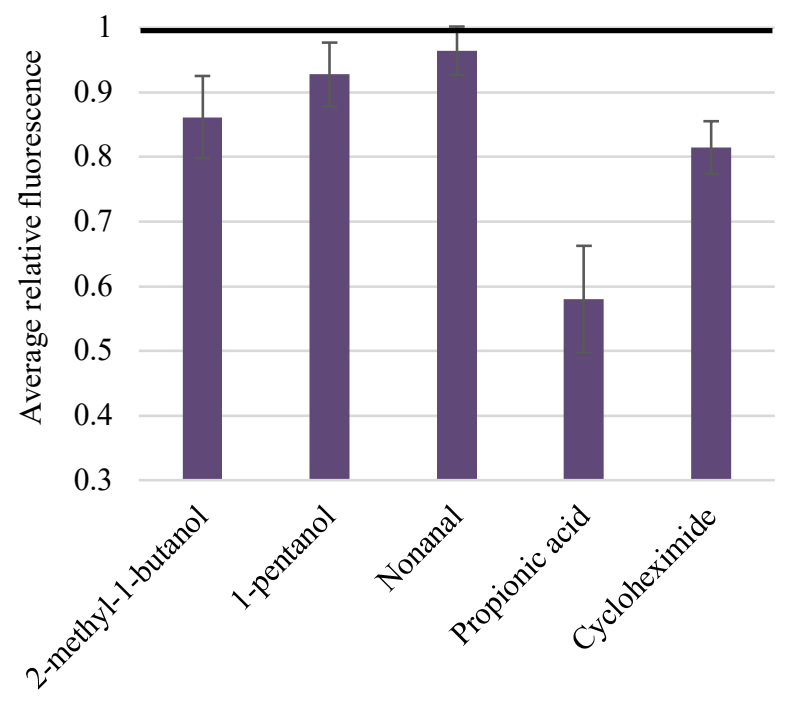

Figure 2.12. Effects of compounds on expression of GFP-tagged proteins. Three cell lines of yeast that express GFP as gene fusion constructs (TPK2-GFP, PIN4-GFP, and PSK2-GFP) were each separately exposed to sub-inhibitory concentrations of each volatile compound and then photobleached. Fluorescence recovery after 2 hours was measured using a flow cytometer and is expressed relative to the fluorescence in a no-treatment control (solid black line). As a positive control, $35 \mu \mathrm{g} \mathrm{ml}^{-1}$ cycloheximide was used. For each condition, Figure A shows the fluorescence values for each of the cells lines individually $(n=1$ biological replicate with 3 experimental replicates). Figure B shows the average fluorescence values across the three cell lines, with error bars showing standard error.

\section{Discussion}

In this chapter we used a yeast model to conduct a preliminary assessment of the antifungal mechanism of action of four compounds that inhibit the bat pathogen Pseudogymnoascus destructans. A yeast single-gene deletion array was separately exposed to sub-inhibitory concentrations of each volatile compound and sensitive mutants were identified. Gene ontology searches were performed to identify candidate pathways and the involvement of these pathways in compound response was validated with secondary assays. Based on results of 
the deletion arrays, we examined the effect of the compounds on oxidative stress, endocytosis, cell cycle progression, membrane permeability, cellular respiration, and gene expression.

The sensitive mutants, enriched gene ontology pathways, and phenotypes resulting from exposure to 2-methyl-1-butanol and 1-pentanol were nearly identical and sometimes overlapped with those resulting from propionic acid exposure, while nonanal appeared to have a unique profile, suggesting a distinct mechanism of action. The structure and biosynthetic origins of these compounds reflects this pattern in activity. 2-methyl-1-butanol and 1-pentanol are both relatively short-chain fusel alcohols, whereas propionic acid is a relatively short-chain carboxylic acid. In contrast, nonanal is a long straight-chain aldehyde. In yeast, 1-pentanol and 2-methyl-1-butanol are derived from amino acid catabolism (Hazelwood et al., 2008; Dickinson, 2008), while propionyl-CoA, an intermediate in propionic acid metabolism, is also produced in isoleucine catabolism (Pronk et al., 1994). Additionally, some bacteria produce propionic acid from the catabolism of amino acids (Ganesan et al., 2004a; Elsden and Hilton, 1978; Ganesan et al., 2004b). In contrast, nonanal is formed from lipid peroxidation, which can occur during oxidative stress (O’Brien et al., 2005; Tagnon and Simeon, 2017). Amino acids are generally catabolized during nitrogen starvation (Ashe et al., 2001) and as end-products or intermediates in amino acid catabolism, 1-pentanol, 2-methyl-1-butanol, and propionic acid could act in part by signalling nitrogen starvation to the cell. While signalling roles for propionic acid are not established, 2methyl-1-butanol and 1-pentanol have signalling roles in inducing yeast filamentous growth, which is typically a response to nitrogen starvation (Hazelwood et al., 2008; Dickinson, 2008).

We did not observe any treatment-mediated changes in the fluorescence of cells treated with $2^{\prime}, 7^{\prime}$-dichlorofluorescein diacetate, which is converted to a fluorescent product during oxidative stress. Previous research has shown conflicting results on whether propionic acid 
causes oxidative stress (Semchyshyn et al., 2011; Piper, 1999; Yun and Lee, 2016); however, our findings suggest that under the conditions we explored, propionic acid does not induce oxidative stress in yeast. Similarly, nonanal is formed from lipid peroxidation during oxidative stress (O'Brien et al., 2005; Tagnon and Simeon, 2017), and our findings are consistent with nonanal functioning in pathways downstream of (and not causing) oxidative stress. However, our findings conflict with previous work with 2-methyl-1-butanol that reported a low-concentration of 2-methyl-1-butanol induced oxidative stress, as measured by lipid peroxidation, in Colletotrichum spp. (filamentous fungi; Rezende et al., 2015). It is possible that the delivery, dose, taxonomy, and/or method account for the differences in our observations.

We observed a striking increase in the uptake of lucifer yellow, a marker of fluid-phase endocytosis, in yeast cells treated with propionic acid, but not with the other three volatile compounds investigated. Yeast use endocytosis to uptake nutrients from their surroundings and to recycle or degrade membrane proteins (Feyder et al., 2015; Goode et al., 2015). Although the mechanisms governing the increases in endocytosis were not determined, weak acids such as propionic acid have been shown to damage membranes and disrupt the function of membrane proteins (Mira et al., 2010), activating quality control mechanisms that cause their endocytosis and degradation in the multivesicular body pathway (Babst, 2014; Li et al., 1999). Damaged membrane proteins must be removed to prevent the accumulation of damage to the cell (Li et al., 1999) and genes involved in protein catabolism through the multivesicular body pathway contribute to propionic acid resistance (Mira et al., 2009). This suggests that endocytosis of damaged surface proteins may be part of an adaptive response to propionic acid. In addition to ubiquitination and endocytosis of membrane proteins (Mira et al., 2010), a region of damaged membrane itself may be endocytosed. In animal cells, endocytosis increases dramatically after 
cells are exposed to permeabilizing agents as the cells removal of regions of damaged membrane (Andrews et al., 2014). Although this is not well-studied in yeast, it is possible that membrane lesions are removed in a similar manner.

We observed perturbations in the cell cycle of yeast exposed to sub-inhibitory concentrations of propionic acid, 1-pentanol, and 2-methyl-1-butanol, suggestive of a $\mathrm{G}_{1}$ or Sphase arrest. Cell cycle perturbations have been observed after exposure to the fusel alcohols isoamyl alcohol (Martinez-Anaya et al., 2003) and butanol (La Valle and Wittenberg, 2001); however, these activities have resulted in delayed progression from $\mathrm{G}_{2}$ to $\mathrm{M}$ during fusel alcoholinduced filamentous growth. We did not observe a G2 arrest; instead, both the fusel alcohols and propionic acid caused an increase in the $G_{1}$ and decrease in the $G_{2}$ populations. It is wellestablished that cells can be arrested in $\mathrm{G}_{1}$ - or $\mathrm{S}$-phase due to small cell size, DNA damage, or DNA replication stress (Bertoli et al., 2013; Gerald et al., 2002; Barnum and O'Connell, 2014); however, $\mathrm{G}_{1}$ arrests have also been observed due to membrane permeabilization (Kono et al., 2016) and amino acid starvation (Unger and Hartwell, 1976; Saldanha et al., 2004). In animal cells, isoleucine and leucine deprivation prevent entry into S-phase (Everhart, 1972) and an amino acid availability checkpoint has been proposed in late $\mathrm{G}_{1}$ (Saqcena et al., 2013). It is possible that in yeast, 2-methyl-1-butanol, 1-pentanol, and propionic acid could trigger a metabolic cell cycle arrest by signalling nitrogen or amino acid starvation.

Contrary to our expectations, we did not observe increases in membrane permeability (quantified by propidium iodide entry into live cells) after treatment with any of the compounds. There are previous reports that straight-chain alcohols (Weber and de Bont, 1996), weak organic acids (Ullah et al., 2012), and nonanal (Zhang et al., 2017) all increase membrane permeability, and there is considerable overlap between the downstream effects of membrane permeabilization 
and the effects that we observed. Cells can repair their membranes from permeabilizers within minutes (Idone et al., 2008) or even seconds (McNeil et al., 2000), and the efficacy of this process is proportional to the concentration of the permeabilizer (Idone et al., 2008). It is possible that the concentrations of compounds that we used were below a threshold required for permeabilization, or that at these concentrations, the time required for propidium iodide to enter a permeabilized cell is greater than the time required for the cell to repair permeabilized membranes.

We used the reduction of MTT as a marker for metabolic activity and observed significantly less MTT reduction in yeast treated with propionic acid. Propionic acid has been shown to indirectly inhibit the pyruvate dehydrogenase complex, which links glycolysis and the citric acid cycle by converting pyruvate into acetyl-CoA (Brock and Buckel, 2004). This could cause end-product inhibition of glycolysis and prevent citric acid cycle entry, ultimately decreasing the generation of NADH necessary to reduce MTT. Endpoint MTT reduction was non-significantly lower in cells treated with the fusel alcohols 2-methyl-1-butanol and 1pentanol; however, it is interesting to note that initially, treatment with these compounds increased the rate of MTT reduction. Fermentation is the preferred mode of metabolism in yeast; however, if fusel alcohols signal nitrogen starvation, then the large energy demands of a nitrogen starvation response (Thomsson et al., 2005) could cause upregulation of genes associated with energy generation and oxidative respiration (Mendes-Ferreira et al., 2007). This is supported by the observation that treatment with isoamyl alcohol (a different fusel alcohol) causes an increase in the activity of succinate dehydrogenase (Kern et al., 2004), an enzyme involved in oxidative metabolism that appears to be important for MTT reduction (Riss et al., 2016; Slater et al., 1963). An increase in oxidative metabolism could generate additional NADH and thus increase 
MTT reduction. However, after 1 to 3 hours of exposure to both the fusel alcohols and to propionic acid, the rate of MTT reduction decreased, suggesting that a subsequent inhibition of oxidative metabolism may occur. Additionally, our results also show that the inhibitory effects of propionic acid on metabolism are greater than the effects of 2-methyl-1-butanol and 1-pentanol, suggesting separate modes of action.

We found that treatment with propionic acid appears to decrease gene expression, which could result from inhibition of transcription or translation. Signalling of amino acid starvation can inhibit translation by causing the phosphorylation of eIF2 $\alpha$ (Taylor et al., 2010). However, it is interesting that we did not see a significant decrease in GFP expression in yeast treated with 2methyl-1-butanol or 1-pentanol. Straight chain alcohols cause a downregulation of genes associated with translation and protein synthesis (Fujita et al., 2004) and fusel alcohols have been shown to block translation initiation by inhibiting eIF2B (Taylor et al., 2010; Smirnova et al., 2005). It is possible that the concentration that we used was below a threshold required for an effect on gene expression.

Based on the results that we observed in yeast treated with 1-pentanol, 2-methyl-1butanol, and propionic acid, it would be interesting to examine if these compounds interfere with Target Of Rapamycin (TOR) signalling. TOR is a highly conserved pathway that regulates a diverse set of cellular factors to coordinate growth and development. In yeast, TOR has two paralogs which form signalling complexes: TOR complex 1 and 2 (TORC1 and TORC2; review in: Loewith and Hall, 2011). TORC1 signalling responds to nutritional and stressor cues in the environment to regulate growth, including translation, ribosome biogenesis, cell cycle progression, nutrient uptake, metabolism, autophagy, and the cell wall integrity pathway. While 
less is known about TORC2, it appears to function independently of nutrient cues and regulates the actin cytoskeleton, endocytosis, and sphingolipid metabolism.

The TORC1 pathway responds to nitrogen and amino acid deficiencies, and inhibition of TOR signalling creates a phenotype similar to that of nitrogen starvation (Loewith and Hall, 2011; Loewith 2011). Under natural conditions, amino acid starvation induces inhibition of TORC1, which leads to increased protein turnover via increased endocytosis and processing through the multivesicular body pathway (Jones et al., 2012). In response to low nutrient availability, inhibition of TORC1 can lead to phosphorylation of eIF2- $\alpha$ and subsequent blocking of translation. This in turn can result in a $\mathrm{G}_{1}$ arrest due to decreased translation of the cyclin Cln3, which is required for cells to commit to DNA synthesis (Barbet et al., 1996; Loewith and Hall, 2011; Barnum and O'Connell, 2014). Additionally, in human cells, an amino acid availability checkpoint mediated by mammalian TOR has been proposed in late $\mathrm{G}_{1}$ (Saqcena et al., 2013). Inhibition of TORC1 signalling can also change the phosphorylation state of several key enzymes in glycolysis and nitrogen metabolism (Loewith, 2011). Further, inhibition of TORC1 signalling causes an upregulation of glycolysis and fermentation genes and a downregulation of mitochondrial genes (Ring et al., 2012). Inhibition of these TORC1-associated functions is reminiscent of our observations in cells treated with the fusel alcohols and propionic acid. If 2-methyl-1-butanol, 1-pentanol, and propionic acid cause inhibition of TORC1 signalling, this could account for the phenotypes of increased endocytosis, cell cycle arrest, decreased gene expression, and perturbed metabolism that we observed with these compounds. However, the differences in activity between the compounds, such as the increase in endocytosis with propionic acid but not 1-pentanol or 2-methyl-1-butanol, remains to be explained. Nevertheless, it is striking how many different modes of activity we observed for propionic acid, 
suggesting the possibility that propionic acid may target a central regulator of cellular homeostasis.

Importantly, as this was a preliminary investigation, there are likely other pathways involved in the response to these compounds that we did not investigate. For example, an ontology search with the deleted genes from sensitive mutants showed that terms related to tryptophan and other aromatic amino acid metabolism were significantly enriched for all compounds. In yeast, tryptophan uptake is often inhibited and can become a limiting factor for growth under a variety of adverse conditions (Abe and Iida, 2003), and interestingly, inhibition of TOR signalling can cause increased turnover and degradation of tryptophan permeases (Schmidt et al., 1998). Additionally, ontology terms related to ergosterol and sterol biosynthesis were significantly enriched in yeast treated with 2-methyl-1-butanol, 1-pentanol, and propionic acid. Ergosterol biosynthesis rigidifies the plasma membrane and can be part of the response to increased membrane fluidity due to exposure to straight-chain alcohols (Weber and de Bont, 1996). It is possible that these and other pathways are involved in responses to treatment with these compounds; however, it is worth noting that the ontology terms were not strong predictors for performance in secondary assays. For example, the ontology terms relating to regulation of RNA polymerase II, nuclear chromatin, and chromatin remodelling were enriched exclusively for 2-methyl-1-butanol, and regulation of transcription was enriched for both 2-methyl-1-butanol and 1-pentanol; however, the only effects on gene expression that we observed with our secondary assay (based on photobleaching of GFP-tagged proteins) were for cells treated with propionic acid. It is possible that this discrepancy arises from treating the deletion array screens with volatile compounds and the secondary assays with liquid compounds or from misinterpreting the pathways that ontology terms represent. In particular, we were unable to 
observe any effects of nonanal in our secondary assays. Nonanal, therefore, appears to have a mechanism of action that is distinct from 2-methyl-1-butanol, 1-pentanol, or propionic acid.

There are many outstanding questions on the mechanisms of action of the tested volatile compounds and several limitations to our research that future work should address. Importantly, our assays were conducted with yeast because of the availability of a yeast deletion array; however, these compounds may not have the same mechanisms of action in $P$. destructans. There could be variability due to taxonomic differences or due to concentration-dependent mechanisms of action, since yeast is more resistant to these compounds than P. destructans. Future research should address if the effects of the volatile compounds that we observed in yeast also occur in $P$. destructans.

\section{Conclusions}

In summary, we used a yeast model to examine the antifungal mechanism of action of four volatile compounds that inhibit $P$. destructans: 2-methyl-1-butanol, 1-pentanol, propionic acid, and nonanal. We found that none of the compounds appear to increase oxidative stress or membrane permeability; however, propionic acid, 2-methyl-1-butanol, and 1-pentanol cause changes to the cell cycle. Additionally, propionic acid appears to cause a dramatic increase in endocytosis and disrupt metabolism and gene expression, while nonanal appears to have a mode of action independent from the other compounds. Although future research is needed to fully elucidate the antifungal mechanisms of action of these interesting volatile compounds, we provide a preliminary assessment of how they may inhibit fungi. 


\section{Chapter 3: Testing the efficacy of microbial and volatile inhibitors of Pseudogymnoascus destructans in hibernaculum-like soil microcosms}

Since it was first detected in New York in 2006, Pseudogymnoascus destructans, the causal agent of white-nose syndrome in bats, has spread across the continent and killed millions of bats (Frick et al., 2015; U.S. Fish and Wildlife Service, 2016). The ability of P. destructans to grow as a saprotroph enables it to persist in the hibernaculum environment (Lorch et al., 2013a; Lorch et al., 2013b; Lindner et al., 2011), and this persistence likely contributes to the infection of bats, the expansion of white-nose syndrome across the continent, and the extirpation or extinction of susceptible bat species (Hoyt et al., 2015a; Frick et al, 2017, Reynolds et al., 2015).

Targeting the environmental growth of $P$. destructans could aid in managing white-nose syndrome and could occur through a biocontrol strategy, where hibernacula are inoculated with antagonist microorganisms, and/or through the use of natural products, where antifungal compounds are applied to the hibernaculum environment. We have previously identified several microbial antagonists and microbially-derived volatile compounds that show excellent inhibition of $P$. destructans in bioassays and could be considered as candidate biocontrols and natural products to control $P$. destructans in hibernacula. However, the survival and activity of a microbial biocontrol agent in the environment, as well as the nature of its activity, can be highly variable and depends on complex interactions between biotic and abiotic factors. This may include interactions with the existing microbial community, the density at which the biocontrol agent is inoculated in the environment, substrate features such as texture, moisture, $\mathrm{pH}$, and nutrient sources, as well as environmental features such as oxygen availability and temperature (Alabouvette and Steinberg, 1995; Hoitink and Boehm, 1999; Raaijmakers et al., 2002). 
Additionally, the susceptibility of fungi to antifungals can be affected by environmental factors (e.g. Buchta and Otcenásek, 1996), and the ability of volatile inhibitory compounds to move through hibernaculum sediment and interact with P. destructans is unknown. Thus, to understand the effectiveness of our previously identified microbial and volatile control candidates, it is important to examine their ability to reduce the $P$. destructans reservoir in a hibernaculum-like context.

Microcosm studies have been used to simulate the environment and study a wide variety of microbial interactions in soil (e.g. Providenti et al., 2004; Trevors et al., 1990; Grenni et al., 2012), including the environmental fate of $P$. destructans after exposure to biocontrol candidates (Zhang et al., 2015). DNA-based environmental monitoring is one way to assess the persistence of $P$. destructans in treated microcosms and has been widely used to determine the fate of microbes in the environment, particularly for microbes released from industrial fermentations (e.g. Providenti et al., 2004; Wendt-Potthoff et al., 1994), in bioterrorism simulations (Johnson et al., 2010), and released as biocontrol agents (e.g. Pujol et al., 2006; Oskiera et al., 2017). These methods often involve the extraction of total DNA from environment samples, followed by the PCR-based amplification of a sequence specific to the organism of interest (e.g. Hynes et al., 2006; Providenti et al., 2004; Oskiera et al., 2017).

The use of hibernaculum-like soil microcosms may provide a small-scale simulation of the hibernaculum environment, where $P$. destructans-contaminated hibernaculum sediment can be treated with a natural product or antagonistic control candidate and the abundance of $P$. destructans DNA can be monitored over time. However, soil microcosms cannot truly emulate the natural environment. Microcosms only simulate a defined set of conditions and do not account for the heterogeneity of biotic and abiotic factors between and within hibernacula (e.g. 
Bilecki, 2003; Vanderwolf et al., 2012; Zhang et al., 2014; Reynolds et al., 2015). It is possible that control candidates that perform well in microcosms would fail to have activity under field conditions, and that candidates that do not have activity in microcosms would be effective under natural conditions. Nevertheless, microcosms can provide an informative assessment prior to undertaking field trials.

Our initial screens on agar medium in Petri dishes of microbes co-inoculated with Pseudogymnoascus destructans revealed several excellent biocontrol candidates that, in these bioassays, strongly inhibited $P$. destructans and appeared to act with some degree of specificity (Micalizzi et al., 2017). We also identified four volatile compounds that inhibit $P$. destructans and conducted preliminary assessments of their mechanisms of action. To better assess the capacity of these antagonists to act as biocontrol and chemical control candidates in bat hibernacula, we tested their ability to inhibit $P$. destructans in hibernaculum-like soil microcosms.

\section{Materials and methods}

\section{Preparation of frozen stocks}

For accurate quantitation, frozen stocks were used to inoculate hibernaculum soil. All assays used $P$. destructans strain US-15. P. destructans and antagonists were separately grown in 15-ml falcon tubes in approximately $10 \mathrm{ml}$ PDB (for P. destructans and fungal antagonists) or LB (for the bacterial antagonist). The liquid cultures of fungi were homogenized using a Waring blender and stored in approximately $15 \%$ glycerol at $-80{ }^{\circ} \mathrm{C}$ before enumerating by plating a dilution series. 


\section{Microcosms}

\section{Microcosm soil}

Soil was collected in early August 2016 from hibernacula located approximately $60 \mathrm{~km}$ north of Grand Rapids, Manitoba, and shipped to Ottawa, ON in double Ziploc bags. The bags were slightly opened after receiving and stored at $4{ }^{\circ} \mathrm{C}$ until use in microcosm experiments (ranging from one week to 15 months). The hibernacula from which soil was collected are not known to be contaminated by $P$. destructans.

\section{Microcosms with microbial antagonists}

Hibernaculum soil was homogenized by hand in a plastic bag before $25 \pm 1 \mathrm{~g}$ (approximately $20 \mathrm{ml}$ ) of soil was added into a $125-\mathrm{ml}$ flask that was then sealed with a doublelayer of aluminum foil. Microcosms were prepared in duplicate with no $P$. destructans added (negative control), P. destructans added without an antagonist (positive control), and in experimental conditions where $P$. destructans was co-inoculated with Pantoea ananatis RFA4P2, Penicillium sp. S9A1R, or Trichoderma harzianum RW1A2P antagonists. Frozen stocks of $P$. destructans and antagonists were centrifuged at $5000 \times \mathrm{g}$ for $5 \mathrm{~min}$ and the supernatant was replaced with autoclaved distilled water. A total volume of $500 \mu 1$ of $P$. destructans containing approximately $50 \times 10^{6} \mathrm{CFU}$ and a total volume of $500 \mu 1$ of antagonist containing approximately $25 \times 10^{6} \mathrm{CFU}$ were inoculated, as evenly as possible, into the soil. An equivalent amount of autoclaved distilled water was added to the control flasks. Flasks were sealed with a double layer of foil and placed at $13 \pm 1{ }^{\circ} \mathrm{C}$ for approximately 4 months. Sterile distilled water was added to saturate the soil in the flasks approximately every 40 days. 


\section{Microcosms with volatile compounds}

To assess if volatile compounds could inhibit $P$. destructans in soil microcosms, hibernaculum soil was homogenized by hand in a plastic bag before $10 \pm 0.5 \mathrm{~g}$ of soil was placed into a $125-\mathrm{ml}$ flask and inoculated with $10 \times 10^{6} \mathrm{CFU} P$. destructans in $1 \mathrm{ml}$ of water. A plastic disk was cut to cover the opening of the flask and a cotton applicator stick was bored into the plastic such that the cotton was suspended in the flask approximately $1 \mathrm{~cm}$ above the soil. The cotton was treated with $67.5 \mu 1$ 1-pentanol, $67.5 \mu 12$-methyl-1-butanol, $55 \mu 1$ propionic acid, or $0.875 \mu 1$ nonanal and the top of the flask was covered with foil. No-inoculum and no-treatment controls were included and flasks were placed at $13 \pm 1^{\circ} \mathrm{C}$ for approximately one month.

\section{Culture of volatile-treated microcosm soil}

To assess viability of $P$. destructans after volatile treatment, $0.5 \mathrm{~g}$ of the hibernaculum soil that was treated with volatile compounds as above was inoculated in triplicated into $5 \mathrm{ml}$ of PDB two weeks after treatment. Tubes were covered, but allowed for gas exchange, and placed at $13 \pm 1{ }^{\circ} \mathrm{C}$ for approximately one month.

\section{Detection of $P$. destructans DNA in soil microcosms}

Hibernaculum soil or garden soil (from Ottawa, $\mathrm{ON}$ ) were homogenized by hand in plastic bags before $5 \mathrm{~g}$ of each were added separately to $50 \mathrm{ml}$ flasks. To inoculate flasks with $P$. destructans DNA, approximately $50 \mathrm{mg}$ of $0.5 \mathrm{~mm}$ glass beads were added to an epitube with $2.5 \times 10^{6} \mathrm{CFU} P$. destructans. The tubes were shaken in a Retsch MM301 mixer mill at $30 \mathrm{~Hz}$ three times for 2 minutes, each separated by a 2-minute pause, and then $300 \mu 1$ of ice-cold $95 \%$ ethanol was added before each tube was vortexed and left for 10 minutes. The epitubes were then centrifuged at 15,000 rpm for 3 minutes and the pellet was rinsed with 70\% ethanol and resuspended in distilled water. For each soil type, microcosms were inoculated with $1400 \mu$ of 
distilled water containing $2.5 \times 10^{6} \mathrm{CFU}$ live $P$. destructans, $P$. destructans DNA from $2.5 \times 10^{6}$ $\mathrm{CFU}$, or an uninoculated negative control. Flasks were covered with a double layer of foil and placed at $13 \pm 1{ }^{\circ} \mathrm{C}$.

\section{qPCR detection of $P$. destructans in microcosms}

For all microcosms, total DNA extractions were performed with a Macherey-Nagel NucleoSpin Genomic DNA from Soil kit and quantified using Quant-iT PicoGreen dsDNA Assay Kit, according to the manufacturers' instructions. In the microcosm culture experiment, some replicates formed a floating mat of mycelia on top of the liquid culture, in which case a proportional amount of the mat and liquid fractions were sampled for DNA extraction.

To quantify the abundance of $P$. destructans in microcosm soil, qPCR was performed with primers targeting the Alpha-L Rhamnosidase gene of $P$. destructans (Chaturvedi et al., 2011a). qPCR reactions contained $50 \mathrm{ng}$ of total soil DNA, $10 \mu 1$ of $2 \times \mathrm{KAPA}$ SYBR FAST Bio-Rad iCycler Master Mix, and $0.4 \mu 1$ each of $10 \mu \mathrm{M}$ V1958 forward (5'GGAAGCCGTGGAATGTGAA-3') and 1959a reverse (5'TGCGTTGATACTATTGTCTTTTCTGAA-3') primers (Chaturvedi et al., 2011a), in a final reaction volume of $20 \mu \mathrm{l}$. The amplification was performed in a BioRad CFX Connect RealTime qPCR machine with an initial denaturation at $95^{\circ} \mathrm{C}$ for 3 minutes followed by 40 cycles of 30 seconds at $95^{\circ} \mathrm{C}, 30$ seconds at $60{ }^{\circ} \mathrm{C}$, and 30 seconds at $72{ }^{\circ} \mathrm{C}$. The threshold was arbitrarily set to 100 RFU and cycle at threshold was used as a quantitation measure. 


\section{Results}

We co-inoculated hibernaculum soil with $P$. destructans and one of Trichoderma harzianum RW1A2P, Pantoea ananatis RFA4P2, or Penicillium sp. S9A1R antagonists. The abundance of $P$. destructans was monitored over 118 days and compared to controls. For all three antagonists tested, over time, the abundance of $P$. destructans did not differ from the abundance of $P$. destructans in the no-antagonist control (Figure 3.1). All soil samples that were inoculated with $P$. destructans contained a considerably larger amount of $P$. destructans than the uninoculated control, where $P$. destructans remained below the limit of detection for the duration dof the experiment. 


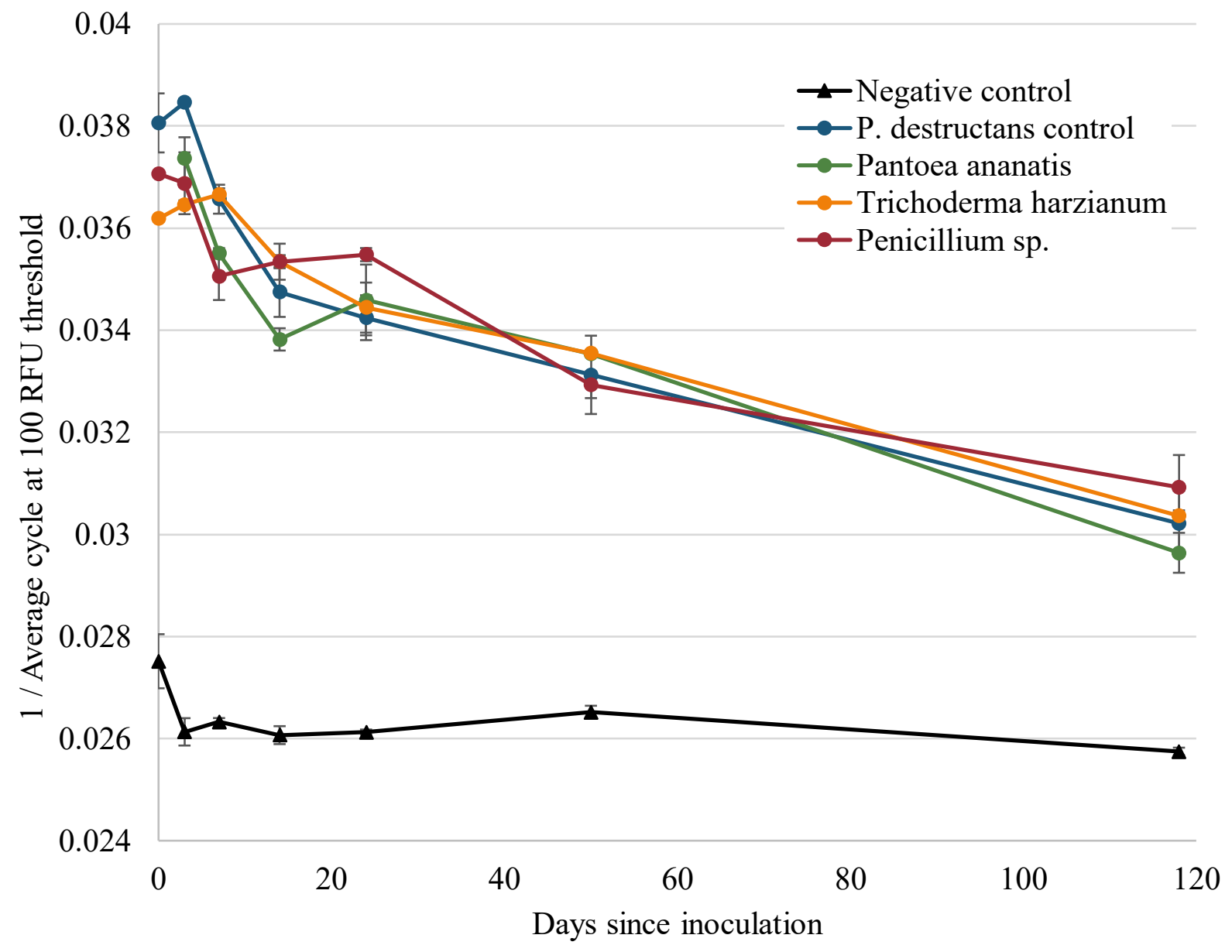

Figure 3.1. Microcosm abundance of $\boldsymbol{P}$. destructans in the presence of microbial

antagonists. Microcosms were uninoculated (control), inoculated with $P$. destructans and no antagonist ( $P$. destructans control), or inoculated with one of three antagonists, and abundance was quantified with qPCR over a 118-day period. $P$. destructans abundance was quantified by the qPCR cycle at an arbitrary $100 \mathrm{RFU}$ threshold. Conditions were performed in duplicate and error bars represent standard error. Triangle markers indicate samples that were below the limit of detection (no amplicon band visible following gel electrophoresis). 
We tested four antifungal volatile compounds for the ability to inhibit $P$. destructans in hibernaculum-like soil microcosms. At the concentrations used, the volatile compounds did not reduce the abundance of $P$. destructans DNA below that of a no-volatile control, and all inoculated conditions contained a much greater abundance of $P$. destructans than the uninoculated control (Figure 3.2). Interestingly, while the abundance of $P$. destructans DNA in soil treated with nonanal was almost identical to the abundance in a no-volatile control, the abundance of $P$. destructans DNA in soil treated with 2-methyl-1-butanol, 1-pentanol, and propionic acid was greater than that in a no-volatile control.

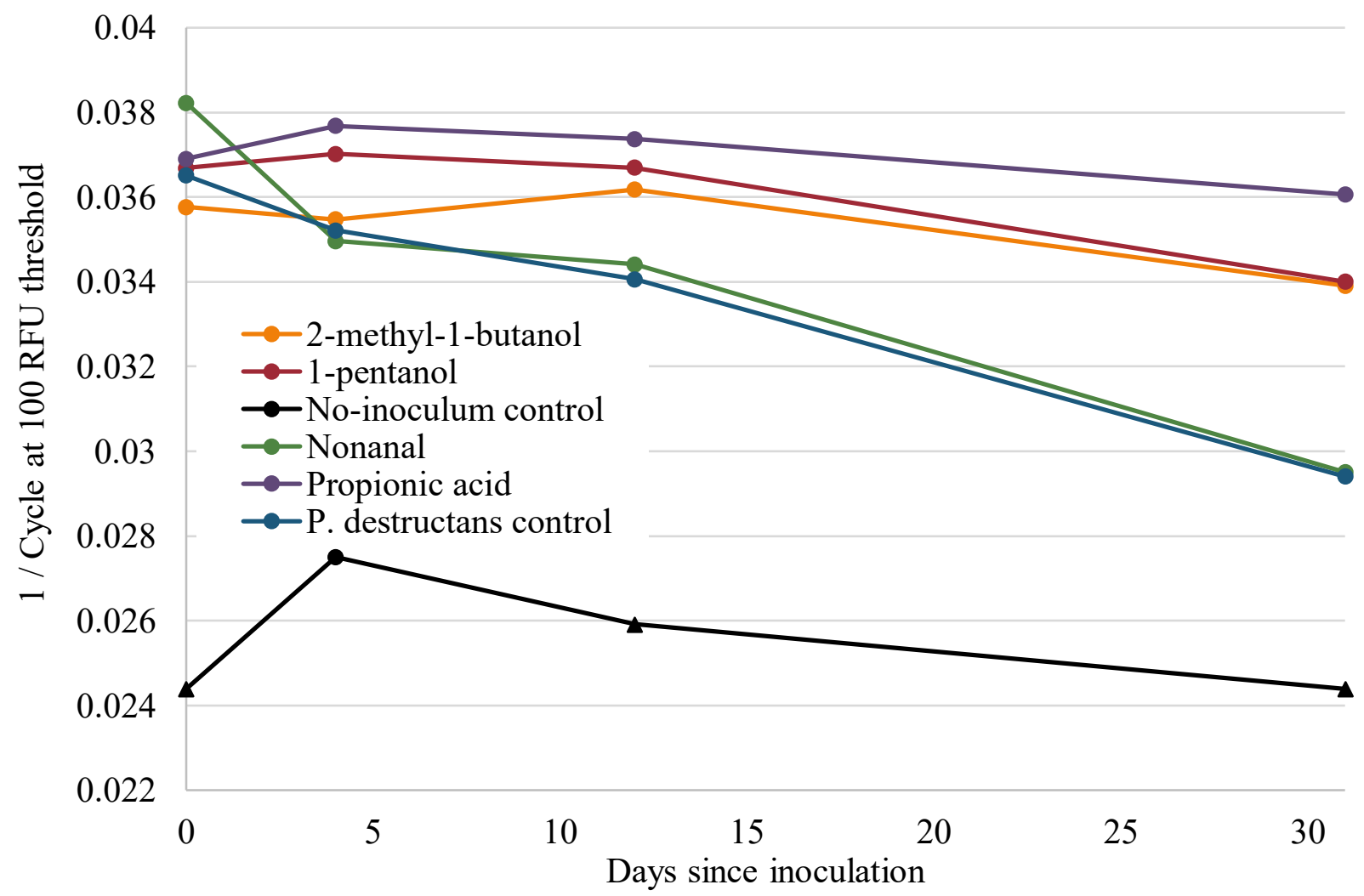

Figure 3.2. Detection of $P$. destructans in hibernaculum-like soil microcosms after fumigation with volatile compounds. $P$. destructans was inoculated into hibernaculum soil in a flask and 1-pentanol, 2-methyl-1-butanol, propionic acid, or nonanal was placed onto a cotton applicator stick suspended above the soil within the flask. Controls without $P$. destructans (no inoculum control) and with $P$. destructans but without volatiles ( $P$. destructans control) were included. $P$. destructans abundance was quantified by the qPCR cycle at an arbitrary 100 RFU threshold. Triangle markers indicate that no amplicon band was visible after gel electrophoresis. 
To assess if the persistence of $P$. destructans DNA in the volatile-treated hibernaculum soil was due to the persistence of live $P$. destructans, we inoculated soil from each of the volatile-treated microcosms and their respective controls into potato dextrose broth (PDB) and measured the relative abundance of $P$. destructans over time in the broth (Figure 3.3). The $P$. destructans control showed a slight decrease in the relative abundance of $P$. destructans over time, while the no-inoculum control remained relatively consistent. The relative abundance of $P$. destructans in cultured soil that was treated with 2-methyl-1-butanol and 1-pentanol rapidly increased in the first week after culturing and then gradually decreased over the rest of the experimental period. In contrast, the relative abundance of $P$. destructans in cultured soil that was treated with nonanal gradually decreased over the first two weeks and then increased again. The relative abundance of $P$. destructans in soil treated with propionic acid decreased at an approximately linear rate over time, and that rate appeared to be greater than in the no-volatile control. The changes in relative $P$. destructans abundance could be attributed to growth of $P$. destructans or microbial degradation of $P$. destructans DNA. Additionally, because the quantification of $P$. destructans in this system was expressed relative to the total abundance of all organisms, a change in the background microbial abundance could alter the relative abundance of $P$. destructans. 


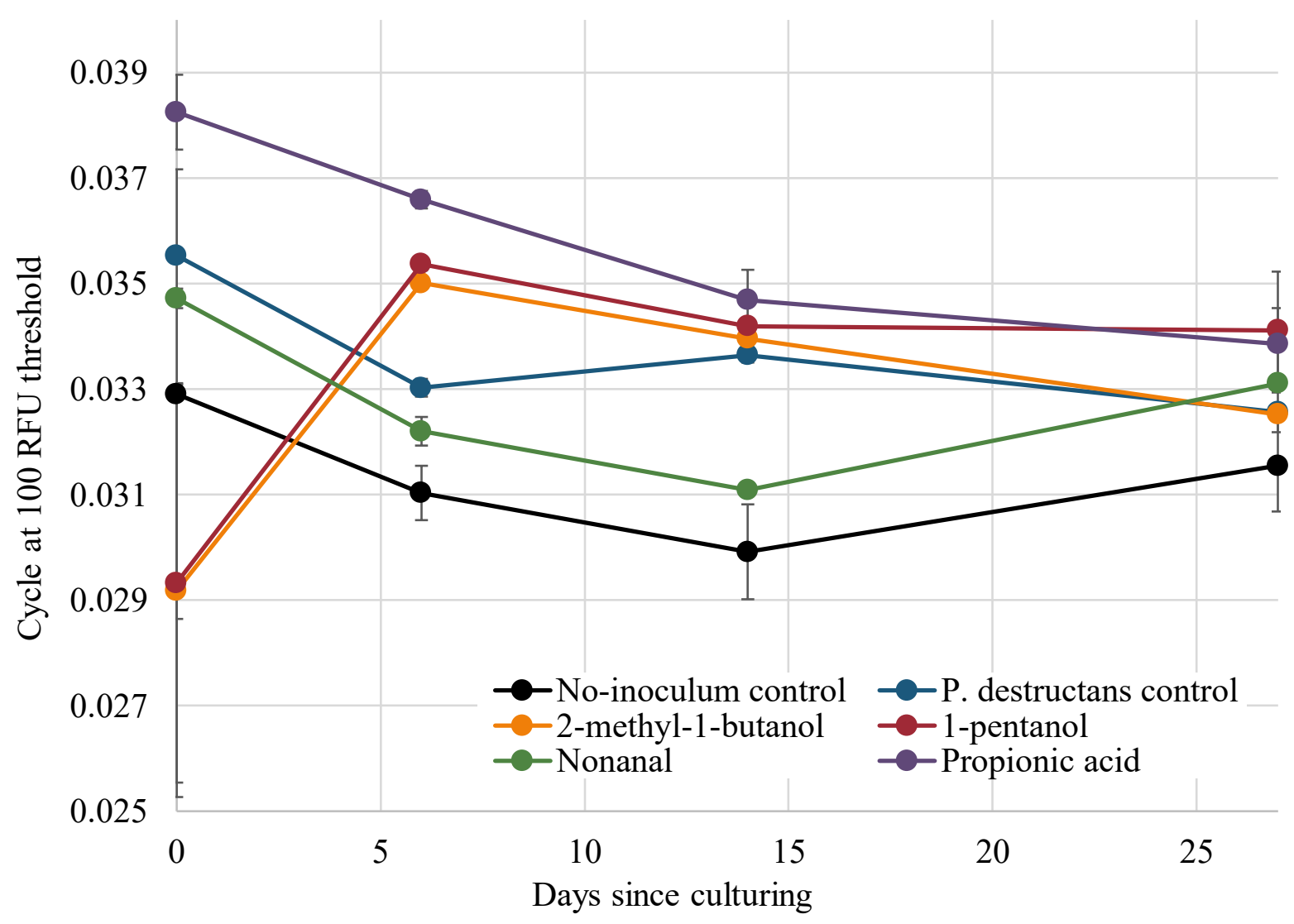

Figure 3.3. Detection of $\boldsymbol{P}$. destructans in microcosm soils cultured in potato dextrose broth over time. Soils that were treated with volatile compounds and then left for 2 weeks were subsequently inoculated into potato dextrose broth and incubated at $13 \pm 1{ }^{\circ} \mathrm{C}$ for approximately 1 month. Values reported are the averages of 3 replicates and error bars show standard error.

To assess whether our quantification of $P$. destructans could include DNA from dead $P$. destructans, we inoculated hibernaculum soil with live $P$. destructans and with extracted $P$. destructans DNA and monitored the abundance of $P$. destructans DNA over time (Figure 3.4a). To assess how the substrate affected the trends that we observed, we repeated the experiment in garden soil (Figure 3.4b). 

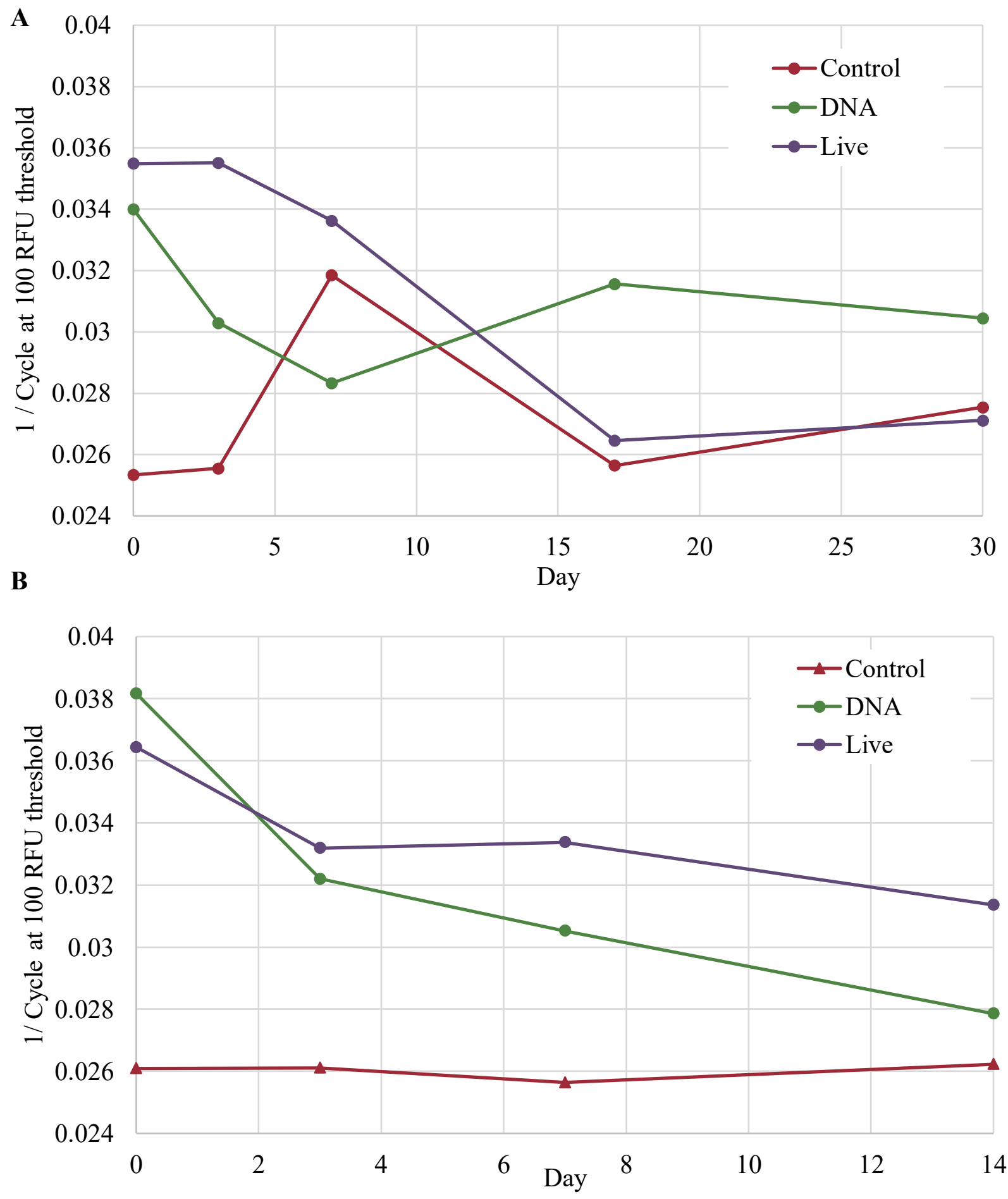

Figure 3.4. Detection of $P$. destructans in hibernaculum soil (A) and garden soil (B) microcosms. Microcosms were uninoculated (control), inoculated with $P$. destructans DNA, or inoculated with live $P$. destructans. The abundance of $P$. destructans DNA was quantified by the qPCR cycle at an arbitrary 100 RFU threshold. Triangle markers indicate that no amplicon band was visible after gel electrophoresis. 
In garden soil, $P$. destructans remained below the limit of detection in an uninoculated control and extracted $P$. destructans DNA that was added directly to uninoculated soil gradually decreased over time. The abundance of live $P$. destructans also slowly decreased over time. In hibernaculum soil, the abundance of extracted $P$. destructans DNA, as well as the abundance of P. destructans in the no-inoculum control fluctuated but remained at levels near the initial abundance at the end of the experiment, while the abundance of live $P$. destructans decreased to near the limit of detection.

\section{Discussion}

We have previously identified microbial antagonists and volatile treatments that inhibit the growth of $P$. destructans in bioassays. As a follow-up to those tests, we used hibernaculumlike soil microcosms to assess if these agents cause inhibition of $P$. destructans in conditions more closely resembling a hibernaculum. Overall, we did not observe any notable decreases in the abundance of $P$. destructans when this bat pathogen was co-inoculated with any one of three microbial antagonists, Trichoderma harzianum RW1A2P, Pantoea ananatis RFA4P2, or Penicillium sp. S9A1R. These antagonists all caused greater than $90 \%$ inhibition of $P$. destructans in bioassays on agar plates (Chapter 1). Similarly, compared to a control, we did not observe any decreases in $P$. destructans abundance in soil microcosms treated with any one of the four volatile compounds previously shown to inhibit P. destructans in bioassays (Chapter 1; Cornelison et al., 2014a).

Several explanations may account for the relatively low efficacy of our treatments in soil microcosms. It is possible that insufficient amounts of biocontrol agents or compounds were used to inhibit $P$. destructans in the soil microcosms. Despite the environmental sources of these 
antagonists (soil, rotten wood, and river foam), nutritional supplementation may be required to support the level of environmental growth required for a biocontrol to affect $P$. destructans abundance (George White, personal communication), and we did not assess antagonist survival in our experiments. For the volatile compounds, we used at least three times the minimum inhibitory concentration (per unit of airspace), required to inhibit P. destructans on agar plates; however, $P$. destructans was inoculated at a high density and microcosm flasks were loosely sealed with foil, allowing the diffusion of compounds out of the flask. Further, we do not know the extent to which the volatile compounds permeate through the soil; however, some reduction of $P$. destructans near the soil surface would be expected regardless of soil permeability, due to the fungicidal nature of 2-methyl-1-butanol, 1-pentanol, and propionic acid (Chapter 1).

In the volatile-treated microcosms, propionic acid was used at the highest concentration (relative to the MIC) and in previous bioassays, appeared to be the least volatile of the four compounds. When microcosms were treated with propionic acid, P. destructans persisted in microcosms more than in any other condition. However, when the treated hibernaculum soil was inoculated into PDB and monitored over time, the relative abundance of $P$. destructans decreased more in propionic acid-treated soil than in any other treatment. This could suggest that propionic acid reduces the viability, and thus abundance, of $P$. destructans in the microcosms, and that our qPCR assay did not effectively quantify the abundance of viable $P$. destructans.

To assess these discrepancies, we monitored microcosms following the addition of extracted $P$. destructans DNA and found that in hibernaculum soil, this DNA only slightly decreased over 30 days. When we repeated the experiment using garden soil, we observed a greater, more rapid decrease in detectable $P$. destructans DNA, suggesting that properties of the hibernaculum soil may contribute to the observed persistence of DNA. Both the mineral 
composition and the microbial activity of soil can affect the degradation of DNA in soil. While DNA in soil is primarily degraded by prokaryotic DNases, degradation can be greatly delayed if DNA binds to soil particles (Blum et al., 1997; Pietramellara et al., 2009; Levy-Booth et al., 2007). The type of soil affects the capacity and kinetics of DNA binding, and clay content is a primary factor that enables soil to bind DNA (Blum et al., 1997; Levy-Booth et al., 2007). Although no chemical analysis of the hibernaculum soil was performed, its clay-like texture could partly explain the persistence of DNA compared to the garden soil that we tested.

Likewise, the hibernaculum soil used had low organic material evident in comparison to the garden soil, which would presumably harbour fewer microbes that could degrade dead $P$. destructans. Reduced growth of the soil microbial community, either due to a low capacity to support growth or treatment-mediated microbial death, could increase the persistence of $P$. destructans DNA by resulting in decreased production of microbial DNases and decreased microbial degradation of the $P$. destructans cell wall.

It is interesting that Zhang et al. (2015) were able to use qPCR-based monitoring in soil microcosms to show that strains of Trichoderma can inhibit Pseudogymnoascus destructans in a simulated hibernaculum environment. One possible explanation for the discrepancy between our findings could be that Zhang et al. inoculated soil with a conidial suspension of $P$. destructans, while we used macerated colonies. Our macerated fragments of $P$. destructans were very dense and ranged from approximately 0.001 to $0.2 \mathrm{~mm}^{2}$, while single $P$. destructans conidia from our strains were approximately $2 \times 10^{-5} \mathrm{~mm}^{2}$. Compared to conidia, the large, highly dense colony forming units that we used would likely be more resistant to compound treatment and microbial antagonism, as well as to degradation of cells and DNA. Additionally, Zhang et al. described a granular consistency to the hibernaculum soil that they used, contrasting with the clay-like 
consistency of our hibernaculum soil. Thus, it is possible that there were differences in the capacity of the soils to bind DNA and protect it from degradation.

It is worth noting that several qPCR-based detection methods of $P$. destructans have been proposed to monitor the environmental abundance of $P$. destructans without controls to determine if they are detecting dead P. destructans (e.g. Shuey et al., 2014; Verant et al., 2016). Our results suggest that under certain conditions, these methods may overestimate the true abundance of viable $P$. destructans.

\section{Conclusions}

Taken together, our results suggest that the qPCR-based detection of $P$. destructans was not a reliable way to assess the survival of $P$. destructans after treatment with different antagonists and volatile compounds. Conditions other than viability, including the composition of soil, the survival and abundance of the microbial community, inoculum density, and rate of degradation of cells and/or DNA may obscure estimates of the abundance of $P$. destructans. While conditions may exist where these techniques can be used successfully, we suggest that environmental monitoring of $P$. destructans should include controls to assess if detection of dead P. destructans is occurring. 


\section{Chapter 4: Antifungal applications to plant pathogens}

It is estimated that to feed the predicted global population, food production will have to increase by over $50 \%$ by 2050 (Royal Society, 2009). Globally, approximately 8 to $15 \%$ of staple crops (wheat, rice, corn, and potatoes) (Oerke, 2006) and a further 25 to $50 \%$ of harvested fruits and vegetables are lost to plant and postharvest pathogens (Sharma et al., 2009; Tripathi and Dubey, 2004). Controlling the growth of agricultural pathogens and food spoilage microbes could contribute to addressing the food requirements of a growing human population.

The most common treatments to control plant pathogens are synthetic contact fungicides, which are increasingly used in Canada due to reduced crop rotation, increased pathogen introduction, increased yield targets, and climate change-induced changes in pathogen distribution (Gossen et al., 2014). However, broad-scale fungicide use is increasingly regulated due to risks of off-target toxicity, carcinogenicity, and persistence (Tripathi and Dubey, 2004; Gossen et al., 2014). Natural products from microbes have been considered as a possible alternative to the use of synthetic fungicides to target plant pathogens. These compounds tend to be biodegradable in the environment, which reduces the risk of environmental toxicity and nontarget effects, and may have novel mechanisms of action, which can help ameliorate the growing problem of multi-class fungicide resistance (Kim and Hwang, 2007; Deising et al., 2008).

We have previously identified antifungal natural products that inhibit Pseudogymnoascus destructans and yeast (Saccharomyces cerevisiae). Because of the importance of controlling the growth and spread of plant pathogens, we screened microbial volatiles and broths containing secreted microbial metabolites against a collection of agriculturally significant plant pathogens. 


\section{Materials and methods}

\section{Plant pathogen strains}

The following strains of plant pathogens were used in volatile and liquid culture assays: Botrytis cinerea 189076, 231370, and RW1A6P, Fusarium oxysporum DAOM 215464 , Alternaria alternata 196949, Alternaria solani DAOM 229596 and 229590, Elsinoë brasiliensis 395825, Sclerotinia sclerotiorum 241671, Fusarium avenaceum RW1A5P, Verticillium dahliae 176 (Laboratoire de diagnostic en phytoprotection; MAPAQ, Québec, Canada), Cryphonectria parasitica EP155, P88-8, and P74-3, Pseudomonas syringae P4326 and Pst DC3000. Morphological examination was used to confirm the identity of the fungal pathogens.

\section{Preparation of plant pathogen stocks}

Fungal plant pathogens were grown separately on potato dextrose agar plates and then removed from the plate and macerated in PDB using a Waring commercial blender. Bacterial plant pathogens were grown in LB broth. Stocks were amended with approximately $15 \%$ glycerol and frozen in $1 \mathrm{ml}$ aliquots at $-80^{\circ} \mathrm{C}$. Thawed stocks were enumerated by plating a dilution series onto potato dextrose agar.

\section{Test of antagonist broths for activity against plant pathogens}

Antagonistic strains previously shown to have antifungal activity in bioassays against $P$. destructans were grown stationary at $13 \pm 1{ }^{\circ} \mathrm{C}$ for 4 weeks in PDB (for fungi and yeast) or LB (for bacteria). The media that the strains grew in was then passed through a Fisher P8 filter paper, $10 \times$ concentrated by lyophilisation, and separated from cells through a $0.22 \mu \mathrm{m}$ syringe filter. The resulting cell-free broths were stored in $100 \mu$ aliquots at $-20{ }^{\circ} \mathrm{C}$ until use in screens 
for antifungal activity against the collection of plant pathogens. All screens were conducted in microtiter plates by $1: 1$ serially diluting $50 \mu 1$ of $10 \times$ broth in $50 \mu 1$ of PDB (for fungi) or LB (for bacteria) and then adding $150 \mu \mathrm{l}$ of PDB or LB containing approximately $100 \mathrm{CFU}$ of plant pathogen. As a negative control, $10 \times$ PDB (for broths from fungal antagonists) or $10 \times$ LB (for broths from bacterial antagonists) was used.

\section{Test of antagonist broth activity over time}

Thirteen of the broths most inhibitory to plant pathogens in initial trials were tested against three of the most sensitive plant pathogens after broths were stored at $-20^{\circ} \mathrm{C}$ for 221 or 292 days. Frozen aliquots of broth were thawed and screened as above, against S. sclerotiorum 241671, Elsinoë brasiliensis 395825, and Cryphonectria parasitica P74-3 and the lowest concentration required for complete inhibition of the plant pathogens was compared to that on day 1 (freshly prepared broths).

\section{Test of volatile activity against plant pathogens}

Plant pathogen stocks were diluted in potato dextrose broth (PDB) and a $5 \mu 1$ drop containing approximately $50 \mathrm{CFU}$ was aliquoted into the centre of a BD Difco Potato Dextrose Agar (PDA) plate. Plates were left at room temperature and growth was monitored daily until mycelial growth was visible. The plate was then inverted and a 2-cm disk of Whatman filter paper was placed into the lid and $50 \mu 1$ of 2-methyl-1-butanol, $50 \mu 1$ of 1-pentanol, $25 \mu 1$ of propionic acid, or $1 \mu l$ of nonanal was added to the filter paper. Plates were then sealed with parafilm and left for 4 hours at room temperature. After the incubation, the plate lids were replaced to remove the source of volatile, and the plates were left unsealed at room temperature. 
Growth was monitored daily for one week after exposure and compared to a no-exposure control.

\section{Results}

We grew antagonists of $P$. destructans stationary in liquid media for one month and screened the concentrated cell-free broth against a collection of 16 plant pathogens spanning 10 species. All plant pathogens were sensitive to at least five of the 33 broths that we tested. Generally, Fusarium spp. and Alternaria alternata were the least sensitive, while strains of Cryphonectria parasitica and Pseudomonas syringae were the most sensitive. Different strains of the same pathogen were usually similar in their sensitivity, with the exception of Alternaria solani, where strain 229590 was resistant to most broths and strain 229596 was among the most sensitive strains that we tested. The three broths with the greatest activity were from Lecanicillium sp. S8I1CN, an unidentified fungus RW3A2Pa, and Trichoderma atroviride RW4A2P, which were strongly inhibitory to most pathogen strains. A few strains were mildly sensitive to the concentrated LB broth control. The inhibition of each pathogen by each antagonist broth, relative to the original broth concentration, is shown in Appendix 5.

We tested a subset of the most inhibitory broths for stability over time. Thirteen broths were stored at $-20{ }^{\circ} \mathrm{C}$ for over 220 days after which their activity against three of the most sensitive plant pathogens was compared to their original activity. Mild variation (activity at 0.5 to $2 \times$ original broth concentration was expected due to minor differences in pipetting and pathogen density, and generally, the activities of the broths did not change with storage. However, the stored broth from Penicillium sp. S8I2ACS had considerably lower activity against Elsinoë brasiliensis than the fresh broth, while after storage, the broth from Bacillus sp. 14807 
and Pseudomonas sp. APCI2P had considerably higher activity against Elsinoë brasiliensis and Cryphonectria parasitica, respectively. The relative activity over time of each broth against each plant pathogen is shown in Table 4.1.

Table 4.1. Antifungal activity of broths over time. Thirteen microbial broths were screened for inhibition of Sclerotinia sclerotiorum 241671, Elsinoë brasiliensis 395825, and Cryphonectria parasitica $\mathrm{P} 74-3$. Stocks were prepared freshly and then prepared again after over 220 days of storage at $-20{ }^{\circ} \mathrm{C}$, Numbers reflect $\frac{C_{\text {fresh broth }}}{C_{\text {stored broth }}}$, where $C$ is the concentration required for complete inhibition (i.e. $<1$ reflects a loss of activity with storage). Numbers with an asterisk indicate that there was no complete inhibition at the highest concentration with the freshly prepared broth, and for calculation purposes, $C_{\text {original }}$ was considered twice the highest concentration used.

\begin{tabular}{c|ccc} 
Broth antagonist strain & S. sclerotiorum & E. brasiliensis & C. parasitica \\
\hline Pseudomonas sp. APCI2P & 2 & 2 & 4 \\
RFA6P & 2 & 2 & 0.5 \\
Lecanicillium sp. S8I1CN & 2 & 1 & 1 \\
Trichoderma atroviride RW4A2P & 1 & 2 & 1 \\
Bacillus sp. APCI1P & 1 & 2 & 1 \\
Bacillus sp. 14807 & 1 & 16 & 1 \\
Bacillus sp. B-14324 & 1 & 1 & 0.5 \\
Pantoea ananatis RFA4P2 & 1 & 1 & 1 \\
Bacillus sp. 55407 & 0.5 & 1 & 1 \\
Trichoderma sp. S3A2ACS & $4 *$ & 2 & 2 \\
Penicillium yarmokense S8A1ACS & 1 & 2 & 1 \\
Penicillium sp. S8I2ACS & $2 *$ & 0.125 & 1
\end{tabular}

We assessed the sensitivity of 12 strains of plant pathogens to a short treatment with volatile compounds that were previously demonstrated to be inhibitory to $P$. destructans and $S$. cerevisiae. Actively growing pathogens were exposed to volatile compounds for 4 hours, after 
which their growth was monitored for one week. The growth of each pathogen before and after exposure to each volatile compound is shown in Figure 4.1. Treatment with nonanal was the least inhibitory to pathogen growth, ranging from having no effect on B. cinerea RW1A6P growth to delaying $V$. dahliae 176 growth for approximately 4 days. Treatment with 1-pentanol and 2-methyl-1-butanol typically caused similar pathogen growth delays, arresting growth for an average of 3.1 and 2.3 days, respectively. This effect was fungistatic and when growth resumed, the rate was comparable to that before treatment. Treatment with propionic acid appeared to have a fungicidal effect on the pathogens and growth typically failed to resume after treatment. In Figure 4.1, propionic acid does not appear to be fungicidal against A. solani 229596 and $B$. cinerea RW1A6P; however, in both cases the filter paper to which propionic acid was applied was not centered in the petri dish. In previous assays, propionic acid appeared to have a low volatility, and in these cases, pathogen growth only resumed on the colony edge furthest from the propionic acid source. 

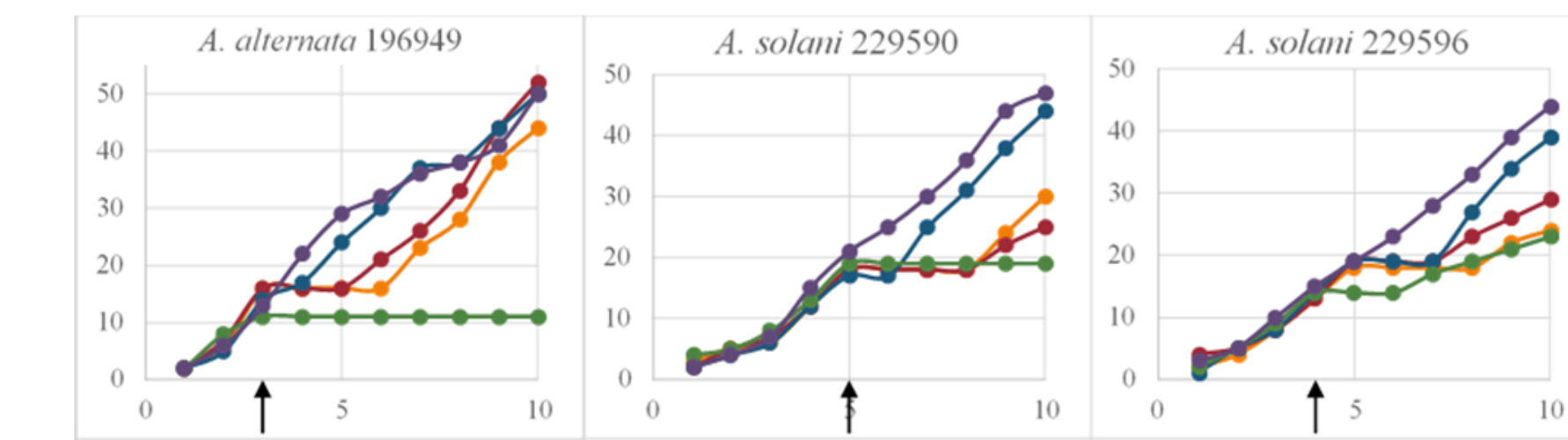

B. cinerea 231370

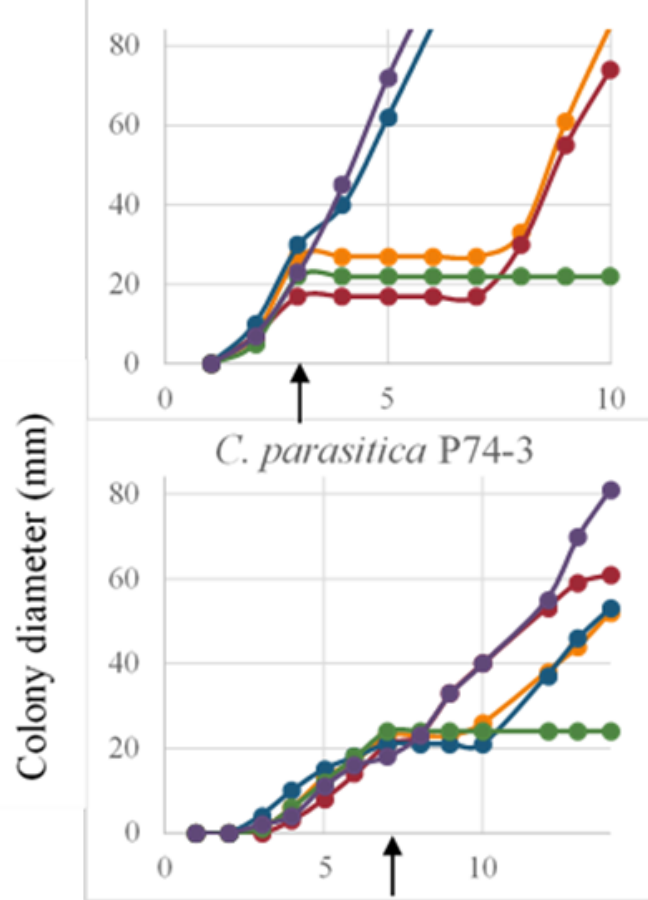

B. cinerea RW1A6P

C. parasitica $\mathrm{EP} 155$

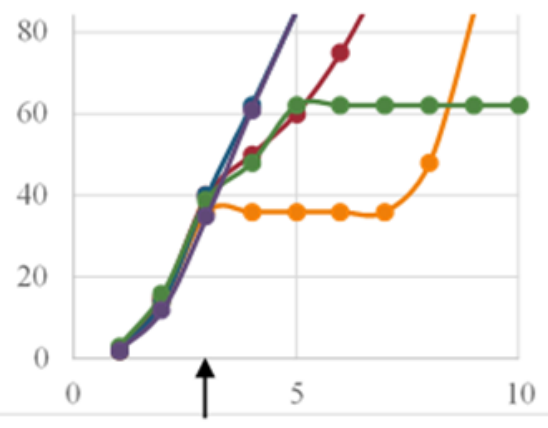

\section{C. parasitica $\mathrm{P} 88-8$}
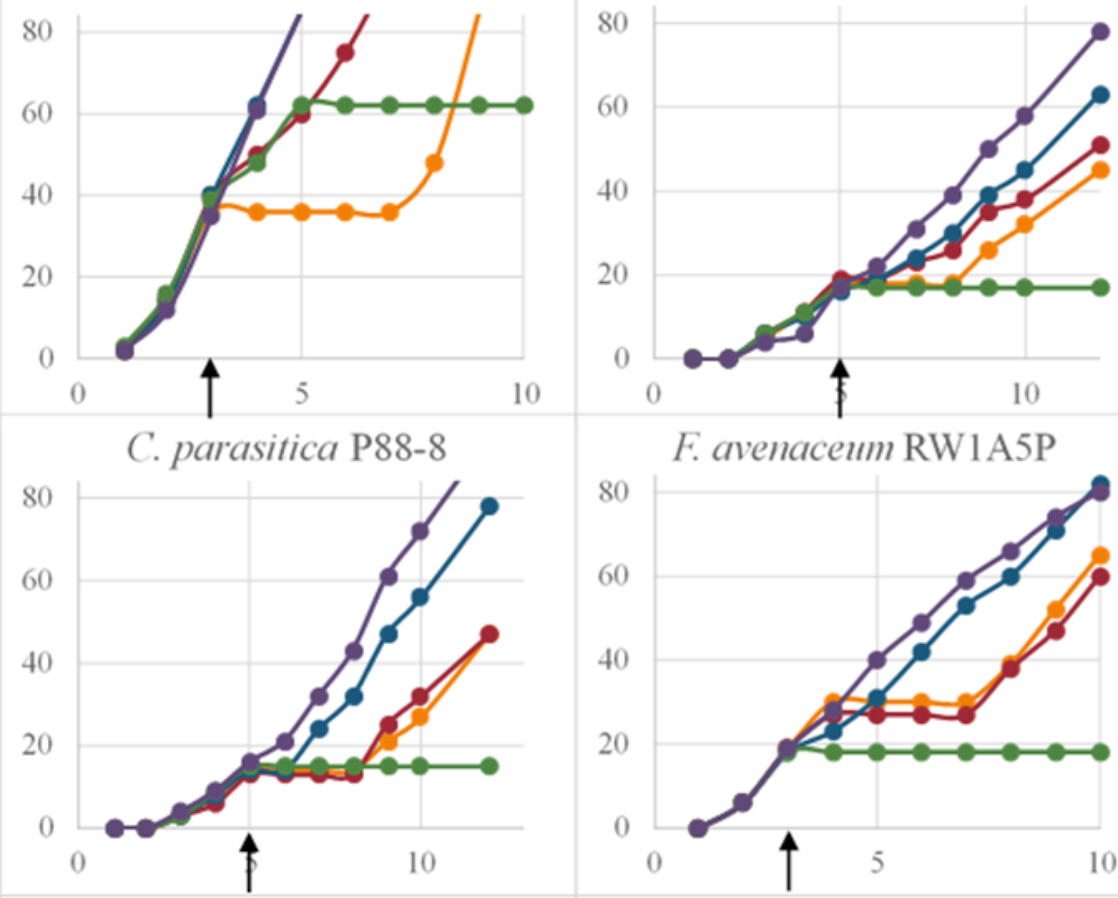

F. avenaceum RW1A5P

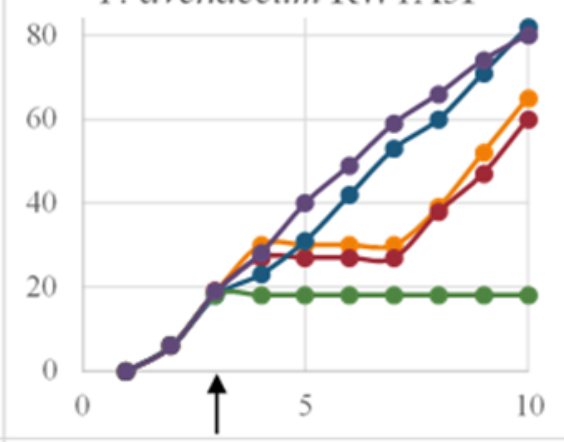
S. sclerotiornm 241671
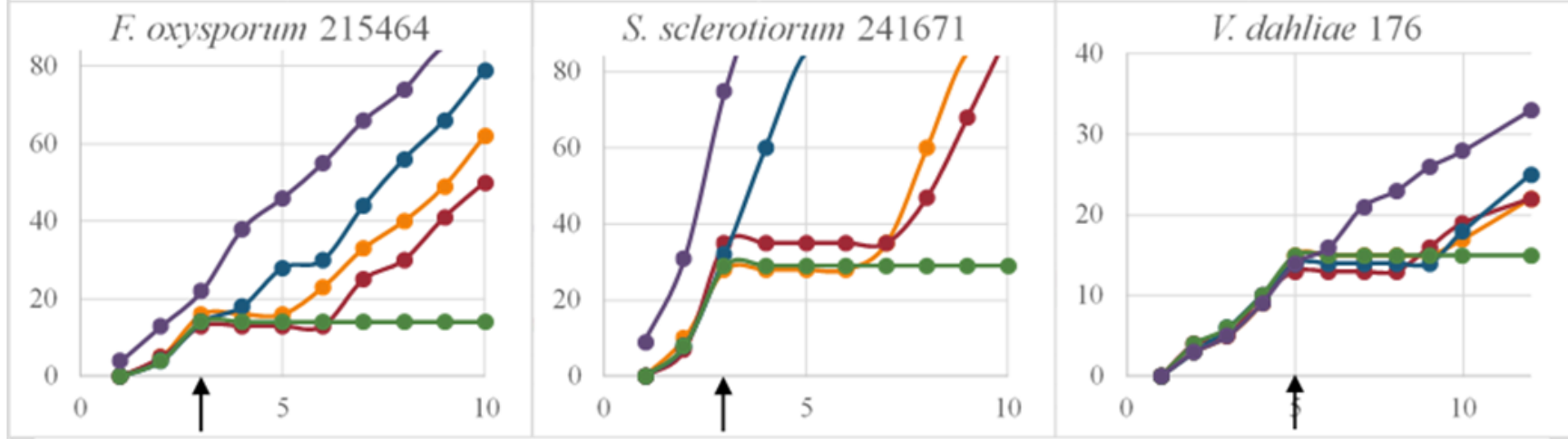

Days since inoculation

$\multimap$-pentanol $\rightarrow$ 2-methyl-1-butanol $\rightarrow$ Nonanal $\multimap$ Propionic acid $\multimap$ Control

Figure 4.1. Growth of 12 strains of plant pathogens exposed to four volatile compounds. Plant pathogens were incubated for 4 hours with $50 \mu 1$ 1-pentanol, $50 \mu 1$ 2-methyl-1-butanol, $1 \mu 1$ nonanal, 25 $\mu 1$ propionic acid, or a no-volatile control. Black arrows indicate the time of volatile exposure. Approximately $50 \mathrm{CFU}$ were inoculated onto PDA plates and exponentially growing colonies were treated with volatiles for 4 hours, after which growth was monitored for 1 week. 


\section{Discussion}

In this work, we identified fungi that constitutively secrete compounds with broad activity against a collection of plant pathogens. The most inhibitory extracts were derived from the spent broth of Trichoderma atroviride, Lecanicillium sp., and an unidentified fungus. The antifungal activity of members of the Trichoderma genus is well established. Trichoderma spp. are known to produce cell wall-degrading enzymes (reviewed in Gruber and Seidl-Seiboth, 2012) and many antibiotic secondary metabolites (reviewed in Zeilinger et al., 2016). Similarly, members of the Lecanicillium genus have been shown to produce lytic and cell wall-degrading enzymes (Nguyen et al., 2015; Bidochka et al., 1999; Rocha-Pino et al., 2011). Based on ITS sequencing, the unidentified antagonist most likely belongs to the genus Phacidium; however, it was sterile in culture and this identification could not be morphologically confirmed. To the best of our knowledge, there are no reports on antifungal activity by extracts of the Phacidium genus, suggesting the possibility of novel antifungal compounds. While it is perhaps not surprising that these fungi were able to produce inhibitory compounds, it is interesting that under the incubation conditions, they were constitutively secreted without induction. Additionally, their apparent stability over time when stored at $-20^{\circ} \mathrm{C}$ makes them attractive candidates for further investigation into their potential industrial use.

In addition to screening crude liquid broths, we showed that under laboratory conditions, short treatments with volatile compounds can have fungistatic or fungicidal activity against a collection of plant pathogens. Volatile natural products are promising candidates for controlling plant pathogens due to their potential to be used as fumigants. These volatile compounds could provide alternatives to traditionally used fumigants such as methyl bromide and metam sodium, which are highly toxic to vertebrates (Yang et al., 1995; Pruett et al., 2001). 1-pentanol and 2- 
methyl-1-butanol showed promising fungistatic inhibition of plant growth and it is possible that this inhibition could be fungicidal at higher concentrations. Propionic acid was particularly effective and had an at least partially fungicidal effect on all tested pathogens. Propionic acid is generally regarded as safe by the U.S. Food and Drug Administration (2017), and while it has been researched and used widely as a food preservative, there has been less research into its potential agricultural use. Our results suggest that volatile natural products could be used to control the growth of plant pathogens in agricultural systems; however, further research is needed to examine the efficacy and safety of these strategies in vivo and under field conditions.

\section{Conclusions}

We conducted preliminary screens of antifungal microbial natural products to determine if any compounds were able to inhibit the growth of a collection of plant pathogens. We identified 33 broths that inhibit a subset of the plant pathogen collection., and these broths were from antagonists that constitutively secrete compounds under the incubation conditions. Most of these compounds appear to be stable for a prolonged period at $-20^{\circ} \mathrm{C}$. We also demonstrate that the plant pathogen collection is sensitive to treatment with three volatile compounds, of which propionic acid was the most promising because it had a fungicidal effect and it is generally regarded as safe. While future research is needed to identify and characterizes these compounds, our work suggests that they could potentially have applications in controlling agriculturally significant plant pathogens. 


\section{General conclusion}

In this set of experiments, we primarily focused on the identification and characterization of candidate control agents for the environmental growth of $P$. destructans, the fungus that causes white-nose syndrome in hibernating bats. We first identified a collection of microbes that were strongly inhibitory to $P$. destructans in bioassays. Further characterization of these antagonistic microbes revealed that they act through contact inhibition, or through secretion of liquid or volatile antifungal compounds (Chapter 1). We examined the microbially-produced volatile compounds 2-methyl-1-butanol, 1-pentanol, propionic acid, and nonanal in further detail and conducted preliminary analyses of the antifungal mode of action of these compounds using a

yeast model (Chapter 2). 2-methyl-1-butanol, 1-pentanol, and propionic acid caused an accumulation of cells in the $\mathrm{G}_{1}$ phase of the cell cycle, while propionic acid further caused an increase in endocytosis and a perturbation of cellular respiration and gene expression. We then simulated the hibernaculum environment with soil microcosms to assess the inhibitory activity of the volatile compounds and a subset of our top antagonists under hibernaculum-like conditions (Chapter 3). Surprisingly, in this system, we did not detect inhibition of $P$. destructans commensurate with our agar-based assays and propose that this may be due to features of the environment and/or treatment that enable the persistence of DNA from dead P. destructans. We suggest that currently employed qPCR-based assays for the detection and quantitation of environmental $P$. destructans should include negative controls to ensure that they are not detecting DNA from dead P. destructans. Finally, we tested the metabolites and volatile compounds that we found to be inhibitory to $P$. destructans against a library of agriculturally significant plant pathogens (Chapter 4). There was a high degree of cross-over of strains that had antifungal activity against $P$. destructans and also against the plant pathogen collection. The 
inhibitory compounds appear to be stable over time under $-20{ }^{\circ} \mathrm{C}$ storage conditions. Future research should further address the antifungal mechanisms of action of these compounds, their ability to inhibit $P$. destructans under hibernaculum conditions, and their employment as antifungals in general. 
Appendix 1. Identification of microbial antagonists of Pseudogymnoascus destructans. Isolates are sorted by percent inhibition, which reflects the degree of inhibition of $P$. destructans by an antagonist. Isolates were ranked as follows: $0=$ negligible $(<50 \%)$ inhibition, $1=$ considerable $(50 \%$ to $85 \%)$ inhibition, $2=$ complete or nearly complete $(>85 \%)$ inhibition. Additionally, if applicable, ranks were qualified with: $\mathrm{A}=$ growth of the antagonist is limited by $P$. destructans, $\mathrm{B}=$ the antagonist grew over $P$. destructans such that affected $P$. destructans colonies were no longer visible, $\mathrm{C}=P$. destructans colonies were present, but uniformly smaller than in the control plate. P. destructans area and isolate diameter refer to sizes 14 days after $P$. destructans was inoculated. Genbank accession numbers refer to sequences of 16S rDNA (bacteria), ITS rDNA (fungi), and beta-tubulin DNA (Penicillium sp.).

\begin{tabular}{|c|c|c|c|c|c|c|c|c|c|c|c|}
\hline \multirow{2}{*}{ Isolate } & \multirow{2}{*}{ Type } & \multirow{2}{*}{ Source $^{1}$} & \multirow{2}{*}{$\begin{array}{c}\text { Source } \\
\text { Location }\end{array}$} & \multirow{2}{*}{ Rank } & \multirow{2}{*}{$\begin{array}{l}\text { Percent } \\
\text { Inhibition }^{4}\end{array}$} & \multirow{2}{*}{$\begin{array}{c}P . \\
\text { destructans } \\
\text { Area } \\
\left(\mathbf{m m}^{2}\right)\end{array}$} & \multirow{2}{*}{$\begin{array}{l}\text { Isolate } \\
\text { Diameter } \\
\quad(\mathbf{m m})\end{array}$} & \multirow{2}{*}{ Identification } & \multicolumn{3}{|c|}{ Genbank Accession Number } \\
\hline & & & & & & & & & $16 \mathrm{~s}$ & ITS & $\beta$-tubulin \\
\hline $\mathrm{S} 7 \mathrm{~A} 3 \mathrm{CVb} 2$ & Bacteria & Soil site 7 & Gatineau, QC & 0 & 3.4 & 499.38 & 11.01 & & & & \\
\hline DUST E & Bacteria & M.L. Smith & Ottawa, ON & 0 & 3.4 & 499.34 & 7.78 & $\begin{array}{c}\text { Bacillus } \\
\text { thuringiensis }\end{array}$ & & & \\
\hline S4A1P & Bacteria & Soil site 4 & Gatineau, QC & 0 & 5.8 & 487.42 & 10.95 & & & & \\
\hline DUST H & Bacteria & M.L. Smith & Ottawa, ON & 0 & 5.8 & 487.21 & 6.40 & Bacillus pumilus & & & \\
\hline M9-1B & Bacteria & $\begin{array}{c}\text { Marine compost (T.J. } \\
\text { Avis) }\end{array}$ & Quebec, QC & 0 & 6.1 & 485.69 & 6.81 & $\begin{array}{c}\text { Bacillus } \\
\text { megaterium }\end{array}$ & KT382244 & & \\
\hline B-14471 & Bacteria & M.L. Smith & Ottawa, ON & 0 & 6.3 & 484.52 & 5.21 & Bacillus subtilis & & & \\
\hline M9-18 & Bacteria & $\begin{array}{c}\text { Marine compost (T.J. } \\
\text { Avis) }\end{array}$ & Quebec, QC & 0 & 7.0 & 481.16 & 9.97 & $\begin{array}{c}\text { Brevibacillus } \\
\text { borstelensis }\end{array}$ & KT382254 & & \\
\hline $\mathrm{S} 2 \mathrm{~A} 2 \mathrm{LC}$ & Bacteria & Soil site 2 & King City, ON & 0 & 7.3 & 479.26 & 13.23 & & & & \\
\hline DUST I & Bacteria & M.L. Smith & Ottawa, ON & 0 & 7.8 & 476.62 & 4.91 & Bacillus pumilus & KY305270 & & \\
\hline $\mathrm{S} 9 \mathrm{~A} 4 \mathrm{~Pb}$ & Bacteria & Soil site 9 & Gatineau, QC & 0 & 7.9 & 476.28 & 12.15 & & & & \\
\hline DUST F & Bacteria & M.L. Smith & Ottawa, ON & 0 & 7.9 & 476.09 & 7.95 & $\begin{array}{c}\text { Bacillus } \\
\text { megatarium }\end{array}$ & & & \\
\hline S9I1P & Bacteria & Soil site 9 & Gatineau, QC & 0 & 8.6 & 472.48 & 9.89 & & & & \\
\hline DUST C & Bacteria & M.L. Smith & Ottawa, ON & 0 & 8.9 & 471.09 & 4.35 & $\begin{array}{c}\text { Bacillus } \\
\text { sphaericus }\end{array}$ & & & \\
\hline IC23 & Bacteria & $\begin{array}{c}\text { Sheep manure compost } \\
\text { tea (T.J. Avis) }\end{array}$ & Quebec, QC & 0 & 9.0 & 470.60 & 8.46 & Bacillus subtilis & KJ689307 & & \\
\hline DUST B & Bacteria & M.L. Smith & Ottawa, ON & 0 & 9.6 & 467.76 & 8.01 & $\begin{array}{c}\text { Bacillus } \\
\text { megatarium }\end{array}$ & & & \\
\hline S8I3P & Bacteria & Soil site 8 & Gatineau, QC & 0 & 10.5 & 462.72 & 9.26 & & & & \\
\hline 14308 & Bacteria & M.L. Smith & Ottawa, ON & 0 & 10.9 & 460.95 & 10.09 & Bacillus sp. & & & \\
\hline
\end{tabular}




\begin{tabular}{|c|c|c|c|c|c|c|c|c|c|c|}
\hline $\mathrm{S} 3 \mathrm{~A} 2 \mathrm{LCb}$ & Bacteria & Soil site 3 & King City, ON & 0 & 11.2 & 459.04 & 10.08 & & & \\
\hline S1A1ACS & Bacteria & Soil site 1 & King City, ON & 0 & 11.8 & 456.39 & 11.26 & & & \\
\hline GWA16 & Bacteria & G.P. White & Ottawa, ON & 0 & 13.0 & 450.15 & 10.11 & & & \\
\hline CU12 & Bacteria & Soil (T.J. Avis) & Ottawa, ON & 0 & 14.6 & 441.76 & 7.50 & Bacillus subtilis & JX489167 & \\
\hline S9A2P2 & Bacteria & Soil site 9 & Gatineau, QC & 0 & 14.7 & 441.19 & 8.85 & & & \\
\hline DUST J & Bacteria & M.L. Smith & Ottawa, ON & 0 & 14.9 & 440.33 & 8.09 & $\begin{array}{c}\text { Bacillus } \\
\text { megatarium } \\
\end{array}$ & KY305271 & \\
\hline $\mathrm{S} 3 \mathrm{~A} 2 \mathrm{P}$ & Bacteria & Soil site 3 & King City, ON & 0 & 15.4 & 437.59 & 15.08 & & & \\
\hline S4A3LC & Bacteria & Soil site 4 & Ottawa, ON & 0 & 15.8 & 435.48 & 9.16 & & & \\
\hline S4I1P & Bacteria & Soil site 4 & Ottawa, ON & 0 & 15.8 & 435.29 & 15.30 & & & \\
\hline PCI5P & Bacteria & Plate contaminant & Ottawa, ON & 0 & 17.8 & 407.47 & 6.25 & Streptomyces sp. & KY305242 & \\
\hline 842 & Bacteria & M.L. Smith & Ottawa, ON & 0 & 18.1 & 423.39 & 5.18 & Bacillus polymyxa & & \\
\hline S8A1P & Bacteria & Soil site 8 & Gatineau, QC & 0 & 18.3 & 422.60 & 11.86 & & & \\
\hline S3A1P & Bacteria & Soil site 3 & King City, ON & 0 & 20.0 & 413.83 & 11.33 & & & \\
\hline $\mathrm{S} 7 \mathrm{~A} 7 \mathrm{~Pb}$ & Bacteria & Soil site 7 & Gatineau, QC & 0 & 20.1 & 413.25 & 9.96 & & & \\
\hline F9-9 & Bacteria & $\begin{array}{c}\text { Forestry compost (T.J. } \\
\text { Avis) }\end{array}$ & Quebec, QC & 0 & 20.2 & 412.69 & 6.71 & $\begin{array}{c}\text { Pseudomonas } \\
\text { koreensis }\end{array}$ & KT382238 & \\
\hline S7A8P & Bacteria & Soil site 7 & Gatineau, QC & 0 & 20.6 & 410.79 & 8.72 & & & \\
\hline $\mathrm{S} 3 \mathrm{~A} 2 \mathrm{LC}$ & Bacteria & Soil site 3 & King City, ON & 0 & 21.6 & 405.66 & 12.48 & & & \\
\hline M9-17 & Bacteria & $\begin{array}{c}\text { Marine compost (T.J. } \\
\text { Avis) }\end{array}$ & Quebec, QC & 0 & 23.0 & 398.46 & 10.48 & $\begin{array}{c}\text { Arthrobacter } \\
\text { psychrophenolicus }\end{array}$ & KT382253 & \\
\hline DUST D & Bacteria & M.L. Smith & Ottawa, ON & 0 & 23.9 & 393.65 & 10.48 & Bacillus sp. & KY305269 & \\
\hline S7A3P & Bacteria & Soil site 7 & Gatineau, QC & 0 & 24.2 & 392.00 & 7.99 & & & \\
\hline M9-19 & Bacteria & $\begin{array}{c}\text { Marine compost (T.J. } \\
\text { Avis) }\end{array}$ & Quebec, QC & 0 & 24.5 & 390.62 & 8.47 & $\begin{array}{c}\text { Rummeliibacillus } \\
\text { pycnus }\end{array}$ & KT382255 & \\
\hline F9-2 & Bacteria & $\begin{array}{c}\text { Forestry compost (T.J. } \\
\text { Avis) }\end{array}$ & Quebec, QC & 0 & 25.4 & 385.68 & 9.97 & Bacillus subtilis & KT382234 & \\
\hline B9-8 & Bacteria & $\begin{array}{c}\text { Bovine manure compost } \\
\text { (T.J. Avis) }\end{array}$ & Quebec, QC & 0 & 25.7 & 384.52 & 5.45 & Bacillus subtilis & KT382230 & \\
\hline 14581 & Bacteria & M.L. Smith & Ottawa, ON & 0 & 26.4 & 380.45 & 12.75 & $\begin{array}{c}\text { Bacillus } \\
\text { megaterium }\end{array}$ & & \\
\hline B9-9B & Bacteria & $\begin{array}{l}\text { Marine compost (T.J. } \\
\text { Avis) }\end{array}$ & Quebec, QC & 0 & 26.5 & 380.37 & 8.93 & $\begin{array}{c}\text { Bacillus } \\
\text { megaterium }\end{array}$ & KT382232 & \\
\hline F9-7 & Bacteria & $\begin{array}{c}\text { Forestry compost (T.J. } \\
\text { Avis) }\end{array}$ & Quebec, QC & 0 & 27.5 & 375.07 & 7.18 & $\begin{array}{l}\text { Pseudomonas } \\
\text { arsenicoxydans }\end{array}$ & KT382236 & \\
\hline M9-7 & Bacteria & $\begin{array}{l}\text { Marine compost (T.J. } \\
\text { Avis) }\end{array}$ & Quebec, QC & 0 & 29.1 & 366.67 & 4.86 & Bacillus subtilis & KT382248 & \\
\hline
\end{tabular}




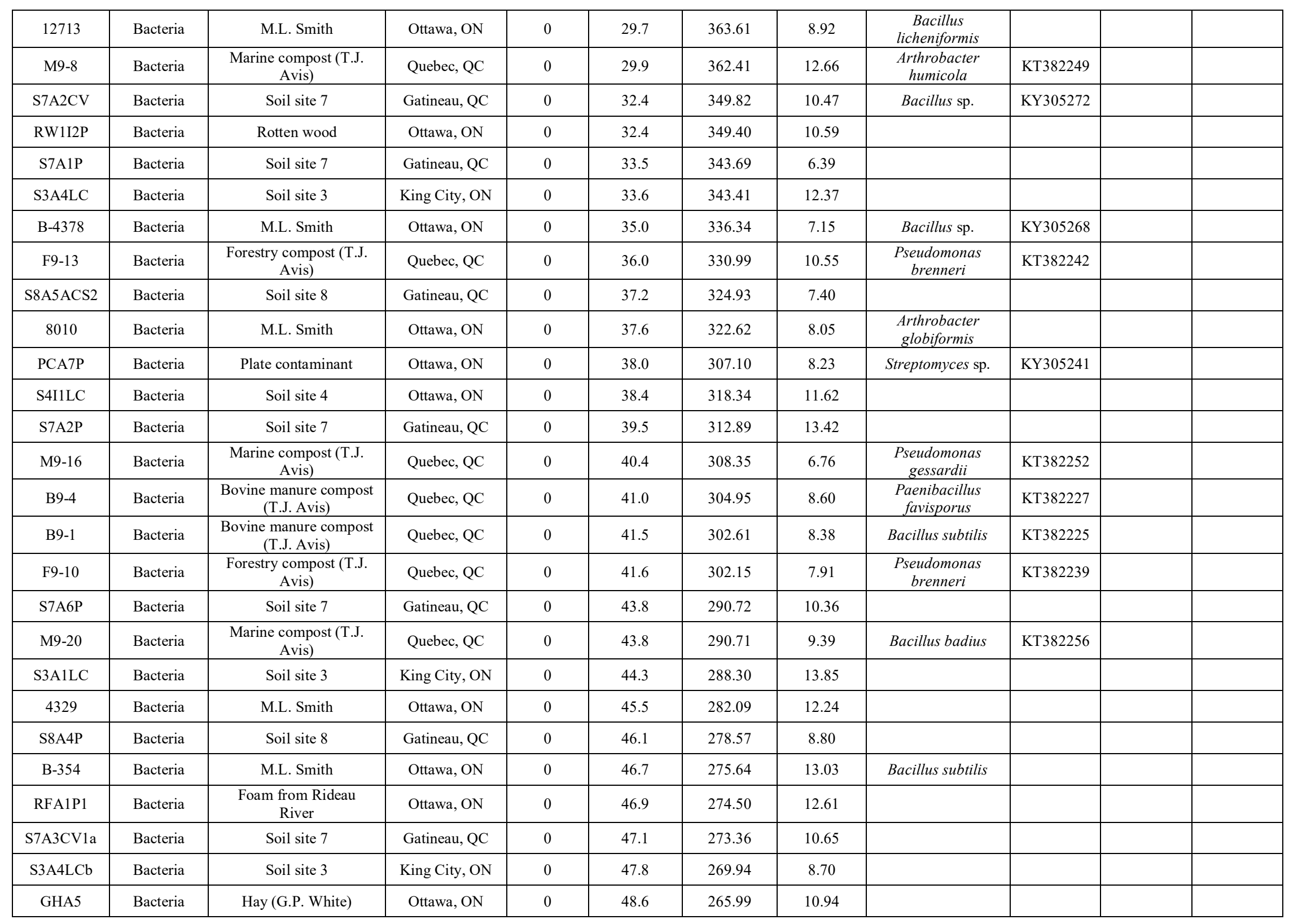




\begin{tabular}{|c|c|c|c|c|c|c|c|c|c|c|c|}
\hline S3A2LCAP & Bacteria & Soil site 3 & King City, ON & 0 & 48.8 & 264.98 & 7.67 & & & & \\
\hline B9-3 & Bacteria & $\begin{array}{l}\text { Bovine manure compost } \\
\text { (T.J. Avis) }\end{array}$ & Quebec, QC & 0 & 49.3 & 261.96 & 11.70 & $\begin{array}{c}\text { Pseudomonas } \\
\text { gessardii }\end{array}$ & KT382226 & & \\
\hline F9-8 & Bacteria & $\begin{array}{c}\text { Forestry compost (T.J. } \\
\text { Avis) }\end{array}$ & Quebec, QC & 0 & 49.7 & 259.99 & 7.29 & Bacillus subtilis & KT382237 & & \\
\hline M9-1 A & Bacteria & $\begin{array}{c}\text { Marine compost (T.J. } \\
\text { Avis) }\end{array}$ & Quebec, QC & 0 & 49.9 & 258.97 & 9.01 & $\begin{array}{c}\text { Arthrobacter } \\
\text { humicola }\end{array}$ & KT382243 & & \\
\hline $13563-0$ & Bacteria & M.L. Smith & Ottawa, ON & 1 & 50.5 & 256.03 & 7.81 & $\begin{array}{c}\text { Bacillus } \\
\text { amyloliquefaciens }\end{array}$ & & & \\
\hline B-23049 & Bacteria & M.L. Smith & Ottawa, ON & 1 & 51.4 & 251.25 & 9.58 & Bacillus subtilis & & & \\
\hline PCI4P & Bacteria & Plate contaminant & Ottawa, ON & 1 & 53.4 & 230.88 & 7.09 & Streptomyces sp. & KY305263 & & \\
\hline S1A2LC & Bacteria & Soil site 1 & King City, ON & 1 & 56.7 & 223.92 & 9.48 & & & & \\
\hline S8A1Cs1 & Bacteria & Soil site 8 & Gatineau, QC & 1 & 57.3 & 220.71 & 11.08 & & & & \\
\hline IB2 & Bacteria & $\begin{array}{c}\text { Sheep manure compost } \\
\text { tea (T.J. Avis) }\end{array}$ & Quebec, QC & 1 & 58.3 & 215.58 & 13.93 & $\begin{array}{l}\text { Aminobacter } \\
\text { aminovorans }\end{array}$ & KJ689311 & & \\
\hline S8A6P & Bacteria & Soil site 8 & Gatineau, QC & 1 & 58.7 & 213.68 & 16.31 & & & & \\
\hline S8I5P & Bacteria & Soil site 8 & Gatineau, QC & 1 & 59.5 & 209.25 & 10.18 & & & & \\
\hline F9-11 & Bacteria & $\begin{array}{l}\text { Forestry compost (T.J. } \\
\text { Avis) }\end{array}$ & Quebec, QC & 1 & 60.4 & 204.81 & 7.24 & $\begin{array}{c}\text { Pseudomonas } \\
\text { moraviensis }\end{array}$ & KT382240 & & \\
\hline 9500 & Bacteria & M.L. Smith & Ottawa, ON & 1 & 60.7 & 203.24 & 10.29 & Bacillus circularns & & & \\
\hline S1A1LC & Bacteria & Soil site 1 & King City, ON & 1 & 60.7 & 202.99 & 9.93 & & & & \\
\hline F9-12 & Bacteria & $\begin{array}{c}\text { Forestry compost (T.J. } \\
\text { Avis) }\end{array}$ & Quebec, QC & 1 & 60.9 & 202.45 & 9.68 & Bacillus subtilis & KT382241 & & \\
\hline DUST A & Bacteria & M.L. Smith & Ottawa, ON & 1 & 61.6 & 198.49 & 11.55 & $\begin{array}{c}\text { Bacillus } \\
\text { thuringiensis }\end{array}$ & & & \\
\hline B9-14 & Bacteria & $\begin{array}{l}\text { Bovine manure compost } \\
\text { (T.J. Avis) }\end{array}$ & Quebec, QC & 1 & 63.7 & 187.75 & 8.36 & Bacillus subtilis & KT382233 & & \\
\hline $6051 \mathrm{~A}$ & Bacteria & M.L. Smith & Ottawa, ON & 1 & 64.2 & 184.98 & 7.72 & Bacillus subtilis & KY305264 & & \\
\hline $\mathrm{S} 8 \mathrm{~A} 3 \mathrm{~Pb}$ & Bacteria & Soil site 8 & Gatineau, QC & 1 & 64.6 & 183.26 & 12.56 & & & & \\
\hline 941 & Bacteria & M.L. Smith & Ottawa, ON & 1 & 65.2 & 179.88 & 7.21 & Bacillus subtilis & & & \\
\hline 4698 & Bacteria & M.L. Smith & Ottawa, ON & 1 & 65.9 & 176.47 & 9.57 & Micrococcus luteus & & & \\
\hline B-363 & Bacteria & M.L. Smith & Ottawa, ON & 1 & 66.5 & 173.32 & 6.03 & Bacillus subtilis & KY305267 & & \\
\hline M9-3 & Bacteria & $\begin{array}{c}\text { Marine compost (T.J. } \\
\text { Avis) }\end{array}$ & Quebec, QC & 1 & 69.6 & 157.09 & 9.83 & Bacillus subtilis & KT382246 & & \\
\hline 55407 & Bacteria & M.L. Smith & Ottawa, ON & $1, \mathrm{C}$ & 71.5 & 147.33 & 11.68 & Bacillus sp. & KY305244 & & \\
\hline PCI6P & Bacteria & Plate contaminant & Ottawa, ON & 1 & 76.3 & 117.56 & 8.34 & Streptomyces sp. & KY305273 & & \\
\hline RW1A1P2 & Bacteria & Rotten wood & Ottawa, ON & $1, \mathrm{C}$ & 76.6 & 121.00 & 8.63 & Rahnella aquatilis & KY305246 & & \\
\hline
\end{tabular}




\begin{tabular}{|c|c|c|c|c|c|c|c|c|c|c|c|}
\hline S5A1P & Bacteria & Soil site 5 & Ottawa, ON & 1 & 79.0 & 108.40 & 11.82 & & & & \\
\hline NRS 213 & Bacteria & M.L. Smith & Ottawa, ON & 1 & 79.6 & 105.45 & 15.98 & Bacillus subtilis & & & \\
\hline S4I1ACS & Bacteria & Soil site 4 & Ottawa, ON & 1 & 82.5 & 86.47 & 8.28 & Streptomyces sp. & KY305251 & & \\
\hline S4A3P & Bacteria & Soil site 4 & Ottawa, ON & $1, \mathrm{C}$ & 83.4 & 85.99 & 13.96 & Arthrobacter sp. & KY305247 & & \\
\hline $\mathrm{S} 4 \mathrm{~A} 2 \mathrm{LCb}$ & Bacteria & Soil site 4 & Ottawa, ON & $2, \mathrm{C}$ & 85.5 & 75.16 & 14.56 & Bacillus sp. & KY305249 & & \\
\hline DUST G & Bacteria & M.L. Smith & Ottawa, ON & $2, \mathrm{C}$ & 85.9 & 73.07 & 11.18 & Bacillus sp. & KY305245 & & \\
\hline M9-4 & Bacteria & $\begin{array}{c}\text { Marine compost (T.J. } \\
\text { Avis) }\end{array}$ & Quebec, QC & 2 & 86.8 & 68.43 & 7.47 & Bacillus subtilis & KT382247 & & \\
\hline PCI1P & Bacteria & Plate contaminant & Ottawa, ON & 2 & 88.6 & 56.49 & 18.74 & Streptomyces sp. & KY305262 & & \\
\hline S9A1Cs1 & Bacteria & Soil site 9 & Gatineau, QC & $2, \mathrm{C}$ & 89.2 & 55.70 & 14.04 & Bacillus subtilis & KY305248 & & \\
\hline B9-7 & Bacteria & $\begin{array}{c}\text { Bovine manure compost } \\
\text { (T.J. Avis) }\end{array}$ & Quebec, QC & 2 & 89.4 & 55.05 & 9.57 & Bacillus subtilis & KT382229 & & \\
\hline S6A3ACS & Bacteria & Soil site 6 & Ottawa, ON & 2 & 90.2 & 48.60 & 4.49 & $\begin{array}{l}\text { Streptomyces } \\
\text { laeteviolaceus }\end{array}$ & KY305253 & & \\
\hline $13540-4$ & Bacteria & M.L. Smith & Ottawa, ON & 2 & 90.5 & 49.24 & 9.74 & Bacillus subtilis & KY305265 & & \\
\hline 14807 & Bacteria & M.L. Smith & Ottawa, ON & 2 & 90.6 & 48.77 & 9.40 & Bacillus sp. & KY305255 & & \\
\hline 55405 & Bacteria & M.L. Smith & Ottawa, ON & $2, \mathrm{C}$ & 91.5 & 43.81 & 8.39 & Bacillus subtilis & KY305250 & & \\
\hline IC10 & Bacteria & $\begin{array}{c}\text { Sheep manure compost } \\
\text { tea (T.J. Avis) }\end{array}$ & Quebec, QC & 2 & 93.4 & 33.89 & 9.54 & Bacillus subtilis & KJ689307 & & \\
\hline B9-9A & Bacteria & $\begin{array}{l}\text { Bovine manure compost } \\
\text { (T.J. Avis) }\end{array}$ & Quebec, QC & 2 & 93.7 & 32.48 & 8.84 & Bacillus subtilis & KT382231 & & \\
\hline M9-14 & Bacteria & $\begin{array}{c}\text { Marine compost (T.J. } \\
\text { Avis) }\end{array}$ & Quebec, QC & 2 & 94.3 & 29.60 & 9.84 & Bacillus subtilis & KT382251 & & \\
\hline M9-9 & Bacteria & $\begin{array}{c}\text { Marine compost (T.J. } \\
\text { Avis) }\end{array}$ & Quebec, QC & 2 & 95.4 & 23.85 & 7.98 & Bacillus subtilis & KT382250 & & \\
\hline OA1I3M & Bacteria & Outdoor air & Ottawa, ON & $2, \mathrm{C}$ & 96.7 & 17.20 & 7.32 & Pantoea sp. & KY305243 & & \\
\hline B9-5 & Bacteria & $\begin{array}{l}\text { Bovine manure compost } \\
\text { (T.J. Avis) }\end{array}$ & Quebec, QC & 2 & 96.8 & 16.47 & 7.09 & Bacillus subtilis & KT382228 & & \\
\hline B-14324 & Bacteria & M.L. Smith & Ottawa, ON & 2 & 97.3 & 13.93 & 9.00 & Bacillus sp. & KY305258 & & \\
\hline GWA3c & Bacteria & G.P. White contaminant & Ottawa, ON & 2 & 97.5 & 12.83 & 12.91 & Bacillus subtilis & KY305259 & & \\
\hline S5A2LC & Bacteria & Soil site 5 & Ottawa, ON & 2 & 98.7 & 6.57 & 18.43 & Pantoea sp. & KY305261 & & \\
\hline APCI1P & Bacteria & Assay plate contaminant & Ottawa, ON & 2 & 99.2 & 3.94 & 10.24 & Bacillus sp. & KY305256 & & \\
\hline RFA4P2 & Bacteria & $\begin{array}{c}\text { Foam from Rideau } \\
\text { River } \\
\end{array}$ & Ottawa, ON & 2 & 99.3 & 3.47 & 18.61 & Pantoea ananatis & KY305260 & & \\
\hline 55406 & Bacteria & M.L. Smith & Ottawa, ON & 2 & 99.4 & 2.98 & 9.35 & Bacillus sp. & KY305266 & & \\
\hline M9-2 & Bacteria & $\begin{array}{c}\text { Marine compost (T.J. } \\
\text { Avis) }\end{array}$ & Quebec, QC & 2 & 99.4 & 2.98 & 7.18 & $\begin{array}{c}\text { Arthrobacter } \\
\text { humicola }\end{array}$ & KT382245 & & \\
\hline
\end{tabular}




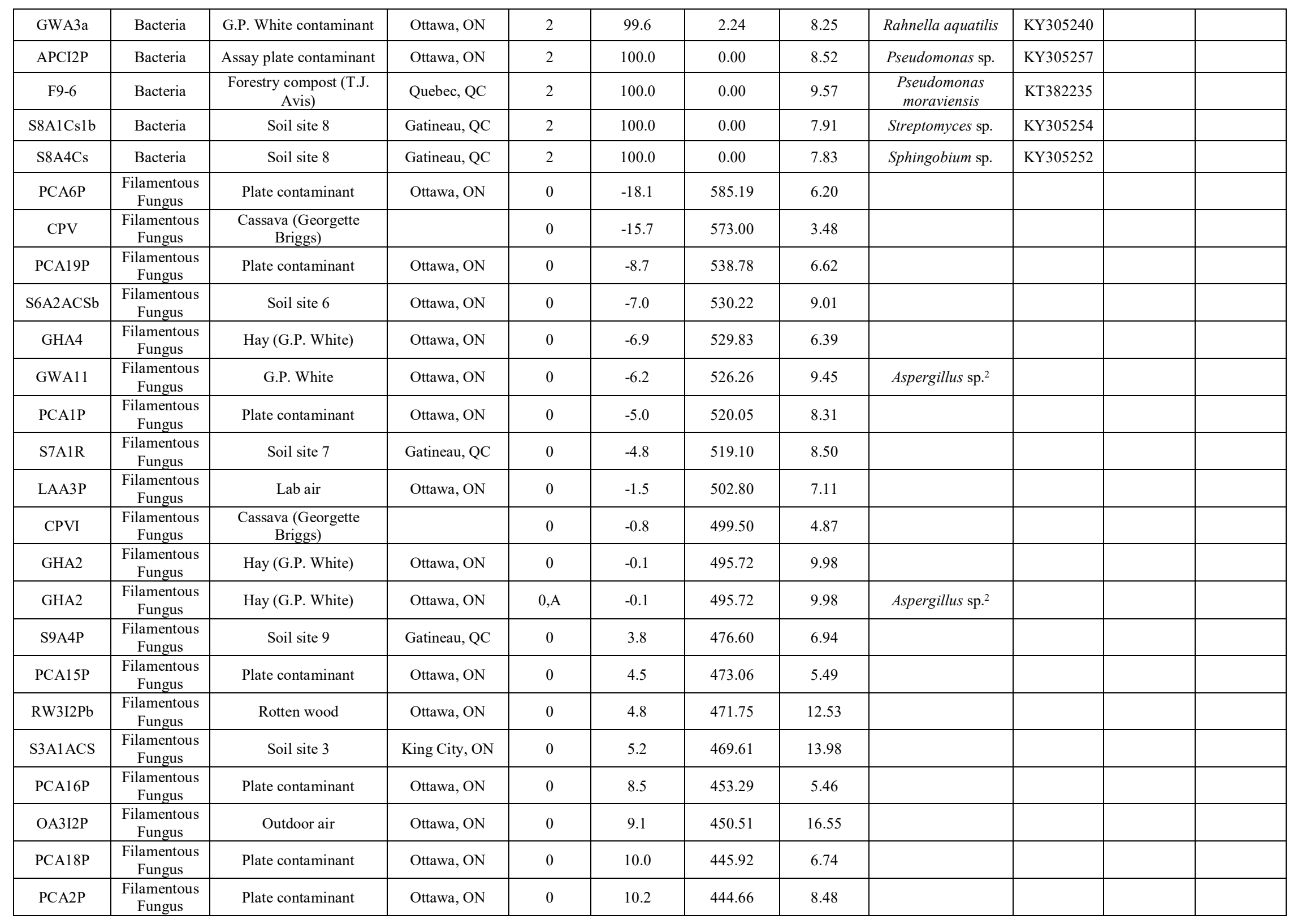




\begin{tabular}{|c|c|c|c|c|c|c|c|c|c|c|}
\hline PCA3P & $\begin{array}{c}\text { Filamentous } \\
\text { Fungus }\end{array}$ & Plate contaminant & Ottawa, ON & 0 & 11.3 & 439.52 & 7.36 & & & \\
\hline PCI7P & $\begin{array}{c}\text { Filamentous } \\
\text { Fungus }\end{array}$ & Plate contaminant & Ottawa, ON & 0 & 11.8 & 436.83 & 6.05 & & & \\
\hline S9A5R & $\begin{array}{l}\text { Filamentous } \\
\text { Fungus }\end{array}$ & Soil site 9 & Gatineau, QC & 0 & 14.2 & 789.83 & 74.60 & & & \\
\hline PCI3P & $\begin{array}{l}\text { Filamentous } \\
\text { Fungus }\end{array}$ & Plate contaminant & Ottawa, ON & 0 & 15.6 & 418.14 & 10.46 & & & \\
\hline RW5A3P & $\begin{array}{l}\text { Filamentous } \\
\text { Fungus }\end{array}$ & Rotten wood & Ottawa, ON & 0 & 18.2 & 752.71 & 62.06 & & & \\
\hline S4A2LC & $\begin{array}{l}\text { Filamentous } \\
\text { Fungus }\end{array}$ & Soil site 4 & Ottawa, ON & 0 & 18.7 & 402.60 & 6.76 & & & \\
\hline PCA11P & $\begin{array}{l}\text { Filamentous } \\
\text { Fungus }\end{array}$ & Plate contaminant & Ottawa, ON & 0 & 21.3 & 390.07 & 10.19 & $\begin{array}{c}\text { Paecilomyces } \\
\text { inflatus }^{2}\end{array}$ & KY305057 & \\
\hline PCI8M & $\begin{array}{l}\text { Filamentous } \\
\text { Fungus }\end{array}$ & Plate contaminant & Ottawa, ON & 0 & 23.2 & 380.54 & 7.25 & & & \\
\hline GHA3 & $\begin{array}{c}\text { Filamentous } \\
\text { Fungus }\end{array}$ & Hay (G.P. White) & Ottawa, ON & 0 & 23.5 & 379.19 & 10.90 & & & \\
\hline PCA17P & $\begin{array}{c}\text { Filamentous } \\
\text { Fungus }\end{array}$ & Plate contaminant & Ottawa, ON & 0 & 23.7 & 378.19 & 10.52 & & & \\
\hline $\mathrm{RW} 3 \mathrm{~A} 2 \mathrm{~Pb}$ & $\begin{array}{l}\text { Filamentous } \\
\text { Fungus }\end{array}$ & Rotten wood & Ottawa, ON & 0 & $24.0^{6}$ & & & & & \\
\hline $\mathrm{S} 8 \mathrm{~A} 3 \mathrm{~Pb}$ & $\begin{array}{l}\text { Filamentous } \\
\text { Fungus }\end{array}$ & Soil site 8 & Gatineau, QC & 0 & $24.0^{6}$ & & & & & \\
\hline S9A3P & $\begin{array}{l}\text { Filamentous } \\
\text { Fungus }\end{array}$ & Soil site 9 & Gatineau, QC & 0 & 26.5 & 364.33 & 20.04 & & & \\
\hline S8A6ACS & $\begin{array}{c}\text { Filamentous } \\
\text { Fungus }\end{array}$ & Soil site 8 & Gatineau, QC & 0 & 26.5 & 364.10 & 21.04 & & & \\
\hline RW1I1P & $\begin{array}{l}\text { Filamentous } \\
\text { Fungus }\end{array}$ & Rotten wood & Ottawa, ON & 0 & 27.1 & 671.06 & 44.88 & & & \\
\hline S8A1R & $\begin{array}{l}\text { Filamentous } \\
\text { Fungus }\end{array}$ & Soil site 8 & Gatineau, QC & 0 & 27.6 & 358.56 & 17.11 & & & \\
\hline GHA7 & $\begin{array}{c}\text { Filamentous } \\
\text { Fungus }\end{array}$ & Hay (G.P. White) & Ottawa, ON & 0 & 27.7 & 358.25 & 11.74 & $\begin{array}{c}\text { Scopulariopsis } \\
\text { brumptii }\end{array}$ & KY305028 & \\
\hline S3A1R & $\begin{array}{l}\text { Filamentous } \\
\text { Fungus }\end{array}$ & Soil site 3 & King City, ON & 0 & 28.4 & 354.93 & 10.21 & & & \\
\hline S9A5P & $\begin{array}{l}\text { Filamentous } \\
\text { Fungus }\end{array}$ & Soil site 9 & Gatineau, QC & 0 & 29.0 & 351.88 & 18.34 & & & \\
\hline OA3I1P & $\begin{array}{l}\text { Filamentous } \\
\text { Fungus }\end{array}$ & Outdoor air & Ottawa, ON & 0 & 29.1 & 652.70 & 32.74 & & & \\
\hline GWA17 & $\begin{array}{l}\text { Filamentous } \\
\text { Fungus }\end{array}$ & G.P. White & Ottawa, ON & 0 & 29.6 & 348.83 & 9.91 & Graphiumsp. $^{2}$ & & \\
\hline GHA6 & $\begin{array}{l}\text { Filamentous } \\
\text { Fungus }\end{array}$ & Hay (G.P. White) & Ottawa, ON & 0 & 29.9 & 347.30 & 17.80 & & & \\
\hline PCA8P & $\begin{array}{l}\text { Filamentous } \\
\text { Fungus }\end{array}$ & Plate contaminant & Ottawa, ON & 0 & 30.1 & 346.52 & 19.53 & & & \\
\hline RW1A3P & $\begin{array}{l}\text { Filamentous } \\
\text { Fungus }\end{array}$ & Rotten wood & Ottawa, ON & 0 & 31.7 & 529.95 & 86.00 & & & \\
\hline
\end{tabular}




\begin{tabular}{|c|c|c|c|c|c|c|c|c|c|}
\hline PCA14P & $\begin{array}{l}\text { Filamentous } \\
\text { Fungus }\end{array}$ & Plate contaminant & Ottawa, ON & 0 & 32.1 & 336.61 & 11.96 & $\begin{array}{c}\text { Paecilomyces } \\
\text { inflatus }^{2}\end{array}$ & KY305080 \\
\hline S8A3R & $\begin{array}{l}\text { Filamentous } \\
\text { Fungus }\end{array}$ & Soil site 8 & Gatineau, QC & 0 & 32.6 & 334.10 & 21.27 & & \\
\hline S9A1P & $\begin{array}{c}\text { Filamentous } \\
\text { Fungus }\end{array}$ & Soil site 9 & Gatineau, QC & $0, \mathrm{~A}$ & 33.4 & 612.93 & 66.60 & & \\
\hline GWI3 & $\begin{array}{l}\text { Filamentous } \\
\text { Fungus }\end{array}$ & G.P. White & Ottawa, ON & 0 & 33.5 & 329.59 & 14.21 & Stachybotrys sp. ${ }^{2}$ & \\
\hline PCI9P & $\begin{array}{l}\text { Filamentous } \\
\text { Fungus }\end{array}$ & Plate contaminant & Ottawa, ON & 0 & 33.7 & 328.55 & 7.71 & & \\
\hline $\mathrm{S} 7 \mathrm{~A} 3 \mathrm{CVb}$ & $\begin{array}{c}\text { Filamentous } \\
\text { Fungus }\end{array}$ & Soil site 7 & Gatineau, QC & 0 & 35.9 & 317.50 & 18.58 & & \\
\hline $\mathrm{OA} 2 \mathrm{I} 3 \mathrm{M}$ & $\begin{array}{l}\text { Filamentous } \\
\text { Fungus }\end{array}$ & Outdoor air & Ottawa, ON & 0 & 36.4 & 585.55 & 33.49 & Cladosporium sp. & KY305029 \\
\hline GWA14 & $\begin{array}{c}\text { Filamentous } \\
\text { Fungus }\end{array}$ & G.P. White & Ottawa, ON & 0 & 36.6 & 314.27 & 19.25 & $\begin{array}{c}\text { Paecilomyces } \\
\text { variotii }^{2} \\
\end{array}$ & \\
\hline S7A7P & $\begin{array}{c}\text { Filamentous } \\
\text { Fungus }\end{array}$ & Soil site 7 & Gatineau, QC & 0 & 37.7 & 308.75 & 9.64 & & \\
\hline PCA9P & $\begin{array}{l}\text { Filamentous } \\
\text { Fungus }\end{array}$ & Plate contaminant & Ottawa, ON & 0 & 37.8 & 308.40 & 17.03 & & \\
\hline GHA1 & $\begin{array}{l}\text { Filamentous } \\
\text { Fungus }\end{array}$ & Hay (G.P. White) & Ottawa, ON & 0 & 38.0 & 307.24 & 11.86 & & \\
\hline S8A5ACS1 & $\begin{array}{c}\text { Filamentous } \\
\text { Fungus }\end{array}$ & Soil site 8 & Gatineau, QC & 0 & 38.0 & 307.21 & 19.47 & $\begin{array}{c}\text { Pseudogymnoascus } \\
\text { pannorum }^{2}\end{array}$ & KY305034 \\
\hline S6A1R & $\begin{array}{l}\text { Filamentous } \\
\text { Fungus }\end{array}$ & Soil site 6 & Ottawa, ON & 0 & 38.1 & 570.07 & 69.50 & & \\
\hline S8A5P & $\begin{array}{c}\text { Filamentous } \\
\text { Fungus }\end{array}$ & Soil site 8 & Gatineau, QC & 0 & 38.5 & 304.52 & 22.98 & & \\
\hline S8A4R & $\begin{array}{c}\text { Filamentous } \\
\text { Fungus }\end{array}$ & Soil site 8 & Gatineau, QC & 0 & 38.6 & 304.41 & 18.42 & & \\
\hline S7A5P & $\begin{array}{l}\text { Filamentous } \\
\text { Fungus }\end{array}$ & Soil site 7 & Gatineau, QC & 0 & 39.4 & 300.39 & 28.10 & $\begin{array}{c}\text { Paecilomyces } \\
\text { lilacinus }^{2}\end{array}$ & \\
\hline $\mathrm{S} 8 \mathrm{I} 3 \mathrm{CN}$ & $\begin{array}{c}\text { Filamentous } \\
\text { Fungus }\end{array}$ & Soil site 8 & Gatineau, QC & 0 & 40.2 & 296.46 & 17.95 & & \\
\hline S7A4P & $\begin{array}{c}\text { Filamentous } \\
\text { Fungus }\end{array}$ & Soil site 7 & Gatineau, QC & 0 & 40.2 & 296.20 & 6.35 & & \\
\hline $\mathrm{OA} 3 \mathrm{I} 1 \mathrm{~Pb}$ & $\begin{array}{l}\text { Filamentous } \\
\text { Fungus }\end{array}$ & Outdoor air & Ottawa, ON & 0 & 40.6 & 546.90 & 25.83 & & \\
\hline PCA21M & $\begin{array}{c}\text { Filamentous } \\
\text { Fungus }\end{array}$ & Plate contaminant & Ottawa, ON & 0 & 42.9 & 282.81 & 20.54 & & \\
\hline S4A1CV & $\begin{array}{c}\text { Filamentous } \\
\text { Fungus }\end{array}$ & Soil site 4 & Ottawa, ON & $0, \mathrm{~A}$ & 43.3 & 522.19 & 39.69 & Mortierella alpina ${ }^{2}$ & KY305049 \\
\hline S8I1ACS & $\begin{array}{c}\text { Filamentous } \\
\text { Fungus }\end{array}$ & Soil site 8 & Gatineau, QC & $0, \mathrm{~A}$ & 43.6 & 518.60 & 44.00 & & \\
\hline S8A1Cs & $\begin{array}{c}\text { Filamentous } \\
\text { Fungus }\end{array}$ & Soil site 8 & Gatineau, QC & 0 & 43.7 & 278.86 & 6.70 & & \\
\hline LAA2P & $\begin{array}{c}\text { Filamentous } \\
\text { Fungus }\end{array}$ & Lab air & Ottawa, ON & 0 & 43.8 & 517.29 & 38.46 & Cladosporium sp. $^{2}$ & KY305056 \\
\hline
\end{tabular}




\begin{tabular}{|c|c|c|c|c|c|c|c|c|c|c|}
\hline S3I1ACS & $\begin{array}{l}\text { Filamentous } \\
\text { Fungus }\end{array}$ & Soil site 3 & King City, ON & 0 & 43.9 & 278.03 & 14.30 & $\begin{array}{c}\text { Paecilomyces } \\
\text { carneus }^{2}\end{array}$ & KY305032 & \\
\hline $\mathrm{OA} 1 \mathrm{I} 5 \mathrm{Mb}$ & $\begin{array}{l}\text { Filamentous } \\
\text { Fungus }\end{array}$ & Outdoor air & Ottawa, ON & 0 & 44.2 & 276.42 & 5.58 & $\begin{array}{c}\text { Ramularia } \\
\text { vizellae }^{2}\end{array}$ & KY305079 & \\
\hline GWA1 & $\begin{array}{l}\text { Filamentous } \\
\text { Fungus }\end{array}$ & G.P. White & Ottawa, ON & 0 & 45.3 & 270.88 & 14.72 & & & \\
\hline S6A3R & $\begin{array}{l}\text { Filamentous } \\
\text { Fungus }\end{array}$ & Soil site 6 & Ottawa, ON & 0 & 46.5 & 492.20 & 86.00 & & & \\
\hline BWA2P & $\begin{array}{l}\text { Filamentous } \\
\text { Fungus }\end{array}$ & Birch bark & Ottawa, ON & 0 & 47.7 & 481.02 & 41.05 & $\begin{array}{l}\text { Penicillium }^{2} \\
\text { crustosum }^{2}\end{array}$ & KY305052 & KY305094 \\
\hline S8A1CN & $\begin{array}{c}\text { Filamentous } \\
\text { Fungus }\end{array}$ & Soil site 8 & Gatineau, QC & 0 & 48.4 & 255.62 & 21.83 & Penicillium sp. $^{2}$ & & \\
\hline GWA3b & $\begin{array}{l}\text { Filamentous } \\
\text { Fungus }\end{array}$ & G.P. White & Ottawa, ON & 0 & 49.9 & 248.41 & 27.12 & & & \\
\hline QM & $\begin{array}{l}\text { Filamentous } \\
\text { Fungus }\end{array}$ & Soil & Ottawa, ON & $1, \mathrm{~A}, \mathrm{~B}$ & 50.3 & 246.47 & 36.55 & Cladosporium sp. ${ }^{2}$ & KY305065 & \\
\hline GWA8 & $\begin{array}{c}\text { Filamentous } \\
\text { Fungus }\end{array}$ & G.P. White & Ottawa, ON & 1 & 51.0 & 450.54 & 76.15 & & & \\
\hline S8A4ACS & $\begin{array}{c}\text { Filamentous } \\
\text { Fungus }\end{array}$ & Soil site 8 & Gatineau, QC & $1, \mathrm{~A}$ & 52.6 & 436.15 & 72.23 & Mortierella sp. ${ }^{2}$ & & \\
\hline PCA22M & $\begin{array}{l}\text { Filamentous } \\
\text { Fungus }\end{array}$ & Plate contaminant & Ottawa, ON & 1 & 53.7 & 229.34 & 13.66 & $\begin{array}{c}\text { Phialosimplex } \\
\text { caninus }^{2}\end{array}$ & KY305081 & \\
\hline GWA15 & $\begin{array}{c}\text { Filamentous } \\
\text { Fungus }\end{array}$ & G.P. White & Ottawa, ON & $1, \mathrm{~B}$ & 53.9 & 228.37 & 12.75 & & & \\
\hline LAA1P & $\begin{array}{c}\text { Filamentous } \\
\text { Fungus }\end{array}$ & Lab air & Ottawa, ON & 1 & 54.2 & 226.67 & 35.34 & & & \\
\hline GWA9 & $\begin{array}{l}\text { Filamentous } \\
\text { Fungus }\end{array}$ & G.P. White & Ottawa, ON & 1 & 54.4 & 419.53 & 25.60 & Aspergillus niger ${ }^{2}$ & & \\
\hline S6A2CV & $\begin{array}{c}\text { Filamentous } \\
\text { Fungus }\end{array}$ & Soil site 6 & Ottawa, ON & 1 & 54.5 & 419.05 & 86.00 & & & \\
\hline JB PERI-2 & $\begin{array}{l}\text { Filamentous } \\
\text { Fungus }\end{array}$ & M.L. Smith & Peru & $1, \mathrm{~B}$ & 56.4 & 401.16 & 86.00 & $\begin{array}{l}\text { Trichoderma } \\
\text { harzianum } 2\end{array}$ & & \\
\hline RW5A1P & $\begin{array}{c}\text { Filamentous } \\
\text { Fungus }\end{array}$ & Rotten wood & Ottawa, ON & 1,A,B & 57.1 & 212.63 & 36.05 & & & \\
\hline RW1A4P & $\begin{array}{l}\text { Filamentous } \\
\text { Fungus }\end{array}$ & Rotten wood & Ottawa, ON & 1 & 57.6 & 390.62 & 74.50 & & & \\
\hline S4A1 ACS & $\begin{array}{l}\text { Filamentous } \\
\text { Fungus }\end{array}$ & Soil site 4 & Ottawa, ON & $1, \mathrm{~B}$ & 58.1 & 385.82 & 45.35 & $\begin{array}{c}\text { Microsphaeropsis } \\
\text { sp. }^{2}\end{array}$ & KY305064 & \\
\hline RFA7P & $\begin{array}{c}\text { Filamentous } \\
\text { Fungus }\end{array}$ & $\begin{array}{c}\text { Foam from Rideau } \\
\text { River }\end{array}$ & Ottawa, ON & $1, \mathrm{~B}$ & 58.1 & 207.46 & 54.05 & $\begin{array}{c}\text { Microdochium } \\
\text { bolleyi }^{2}\end{array}$ & KY305060 & \\
\hline $\mathrm{S} 3 \mathrm{~A} 2 \mathrm{CV}$ & $\begin{array}{c}\text { Filamentous } \\
\text { Fungus }\end{array}$ & Soil site 3 & King City, ON & 1 & 58.7 & 204.58 & 22.39 & & & \\
\hline PCA4P & $\begin{array}{c}\text { Filamentous } \\
\text { Fungus }\end{array}$ & Plate contaminant & Ottawa, ON & 1 & 59.5 & 200.83 & 25.30 & $\begin{array}{c}\text { Paecilomyces } \\
\text { inflatus }^{2}\end{array}$ & KY305082 & \\
\hline GWI5 & $\begin{array}{c}\text { Filamentous } \\
\text { Fungus }\end{array}$ & G.P. White & Ottawa, ON & $1, \mathrm{~B}$ & 62.2 & 187.26 & 27.19 & $\begin{array}{c}\text { Penicillium } \\
\text { chrysogenum }^{2}\end{array}$ & KY305055 & KY305087 \\
\hline S6A1RQM & $\begin{array}{c}\text { Filamentous } \\
\text { Fungus }\end{array}$ & Soil site 6 & Ottawa, ON & 1 & 62.3 & 347.36 & 70.74 & & & \\
\hline
\end{tabular}




\begin{tabular}{|c|c|c|c|c|c|c|c|c|c|}
\hline $\mathrm{S} 7 \mathrm{~A} 1 \mathrm{CVb}$ & $\begin{array}{l}\text { Filamentous } \\
\text { Fungus }\end{array}$ & Soil site 7 & Gatineau, QC & 1 & 62.8 & 342.13 & 86.00 & & \\
\hline LAI1P & $\begin{array}{l}\text { Filamentous } \\
\text { Fungus }\end{array}$ & Lab air & Ottawa, ON & 1,A,B & 63.6 & 334.99 & 35.87 & Cladosporium sp. ${ }^{2}$ & KY305066 \\
\hline CPK 882 & $\begin{array}{l}\text { Filamentous } \\
\text { Fungus }\end{array}$ & M.L. Smith & Iran & $1, \mathrm{~B}, \mathrm{C}$ & 65.0 & 322.26 & 86.00 & $\begin{array}{c}\text { Trichoderma } \\
\text { pleuroticola } 2\end{array}$ & \\
\hline S3A1CV & $\begin{array}{l}\text { Filamentous } \\
\text { Fungus }\end{array}$ & Soil site 3 & King City, ON & 1 & 65.5 & 317.45 & 75.12 & & \\
\hline $\mathrm{S} 8 \mathrm{~A} 2 \mathrm{CN}$ & $\begin{array}{l}\text { Filamentous } \\
\text { Fungus }\end{array}$ & Soil site 8 & Gatineau, QC & 1 & 65.6 & 170.59 & 18.68 & $\begin{array}{c}\text { Pseudogymnoascus } \\
\text { roseus }^{2}\end{array}$ & KY305084 \\
\hline PCA5P & $\begin{array}{c}\text { Filamentous } \\
\text { Fungus }\end{array}$ & Plate contaminant & Ottawa, ON & 1 & 65.8 & 169.28 & 7.06 & $\begin{array}{c}\text { Paecilomyces } \\
\text { inflatus }^{2}\end{array}$ & KY305083 \\
\hline $\mathrm{S} 4 \mathrm{~A} 2 \mathrm{P}$ & $\begin{array}{l}\text { Filamentous } \\
\text { Fungus }\end{array}$ & Soil site 4 & Ottawa, ON & 1 & 66.8 & 164.50 & 7.06 & & \\
\hline GWA12 & $\begin{array}{l}\text { Filamentous } \\
\text { Fungus }\end{array}$ & G.P. White & Ottawa, ON & 1 & 67.0 & 163.65 & 16.06 & Simplicillium sp. ${ }^{2}$ & KY305078 \\
\hline GWI2 & $\begin{array}{l}\text { Filamentous } \\
\text { Fungus }\end{array}$ & G.P. White & Ottawa, ON & 1 & 67.6 & 160.60 & 35.10 & Penicillium sp. ${ }^{2}$ & KY305033 \\
\hline RFA2P & $\begin{array}{l}\text { Filamentous } \\
\text { Fungus }\end{array}$ & $\begin{array}{c}\text { Foam from Rideau } \\
\text { River }\end{array}$ & Ottawa, ON & 1,A,B & 67.6 & 160.34 & 37.74 & Cladosporium sp. ${ }^{2}$ & KY305058 \\
\hline RFA1P & $\begin{array}{l}\text { Filamentous } \\
\text { Fungus }\end{array}$ & $\begin{array}{c}\text { Foam from Rideau } \\
\text { River }\end{array}$ & Ottawa, ON & $1, \mathrm{~B}$ & 67.8 & 296.26 & 70.15 & & \\
\hline RW2A2P & $\begin{array}{l}\text { Filamentous } \\
\text { Fungus }\end{array}$ & Rotten wood & Ottawa, ON & 1 & 68.0 & 294.25 & 86.00 & & \\
\hline GWI6 & $\begin{array}{l}\text { Filamentous } \\
\text { Fungus }\end{array}$ & G.P. White & Ottawa, ON & 1 & 68.1 & 158.16 & 37.57 & & \\
\hline WSF 2925 & $\begin{array}{l}\text { Filamentous } \\
\text { Fungus }\end{array}$ & M.L. Smith & United States & 1 & 68.7 & 287.77 & 86.00 & $\begin{array}{c}\text { Trichoderma } \\
\text { harzianum }\end{array}$ & \\
\hline S6A2ACSa & $\begin{array}{l}\text { Filamentous } \\
\text { Fungus }\end{array}$ & Soil site 6 & Ottawa, ON & 1 & 69.1 & 152.95 & 10.71 & & \\
\hline RW5A2P & $\begin{array}{l}\text { Filamentous } \\
\text { Fungus }\end{array}$ & Rotten wood & Ottawa, ON & $1, \mathrm{~B}$ & 69.7 & 150.13 & 38.88 & Cladosporium sp. ${ }^{2}$ & KY305063 \\
\hline RFA3P & $\begin{array}{c}\text { Filamentous } \\
\text { Fungus }\end{array}$ & $\begin{array}{c}\text { Foam from Rideau } \\
\text { River }\end{array}$ & Ottawa, ON & $1, \mathrm{~B}$ & 69.9 & 148.94 & 38.35 & Cladosporium sp. ${ }^{2}$ & KY305059 \\
\hline GWA13 & $\begin{array}{c}\text { Filamentous } \\
\text { Fungus }\end{array}$ & G.P. White & Ottawa, ON & 1 & $70.1^{6}$ & & & $\begin{array}{l}\text { Aspergillus } \\
\text { ochraceus }^{2}\end{array}$ & KY305086 \\
\hline GWA7 & $\begin{array}{l}\text { Filamentous } \\
\text { Fungus }\end{array}$ & G.P. White & Ottawa, ON & $1, \mathrm{~B}$ & 71.3 & 264.42 & 56.71 & Alternaria sp. $^{2}$ & KY305053 \\
\hline OA2I6M & $\begin{array}{l}\text { Filamentous } \\
\text { Fungus }\end{array}$ & Outdoor air & Ottawa, ON & 1 & 74.3 & 236.60 & 86.00 & & \\
\hline S7A1ACS & $\begin{array}{l}\text { Filamentous } \\
\text { Fungus }\end{array}$ & Soil site 7 & Gatineau, QC & 1 & 74.9 & 230.82 & 86.00 & & \\
\hline $\begin{array}{c}\text { TUB F- } \\
1005\end{array}$ & $\begin{array}{l}\text { Filamentous } \\
\text { Fungus }\end{array}$ & M.L. Smith & Brazil & 1 & 75.3 & 226.97 & 86.00 & $\begin{array}{c}\text { Trichoderma } \\
\text { harzianum }\end{array}$ & \\
\hline BWA4P & $\begin{array}{c}\text { Filamentous } \\
\text { Fungus }\end{array}$ & Birch bark & Ottawa, ON & $1, \mathrm{C}$ & 76.5 & 216.59 & 86.00 & $\begin{array}{l}\text { Trichoderma } \\
\text { koningiopsis }^{2} \\
\end{array}$ & KY305042 \\
\hline RW1A5P & $\begin{array}{c}\text { Filamentous } \\
\text { Fungus }\end{array}$ & Rotten wood & Ottawa, ON & $1, \mathrm{~A}, \mathrm{~B}$ & 76.5 & 215.93 & 62.97 & $\begin{array}{c}\text { Fusarium } \\
\text { avenaceum }^{2}\end{array}$ & KY305067 \\
\hline
\end{tabular}




\begin{tabular}{|c|c|c|c|c|c|c|c|c|c|c|}
\hline PCA13P & $\begin{array}{l}\text { Filamentous } \\
\text { Fungus }\end{array}$ & Plate contaminant & Ottawa, ON & 1 & 76.8 & 114.71 & 8.54 & Oidiodendron sp..$^{2,3}$ & KY305068 & \\
\hline GWA2 & $\begin{array}{c}\text { Filamentous } \\
\text { Fungus }\end{array}$ & G.P. White & Ottawa, ON & 1 & 77.8 & 203.96 & 86.00 & Trichoderma sp. $^{2}$ & & \\
\hline RW4A3P & $\begin{array}{l}\text { Filamentous } \\
\text { Fungus }\end{array}$ & Rotten wood & Ottawa, ON & 1 & 78.7 & 196.06 & 86.00 & & & \\
\hline JB NZ2-4 & $\begin{array}{c}\text { Filamentous } \\
\text { Fungus }\end{array}$ & M.L. Smith & New Zealand & $1, \mathrm{~B}, \mathrm{C}$ & 78.9 & 194.24 & 86.00 & $\begin{array}{l}\text { Trichoderma } \\
\text { harzianum } 2\end{array}$ & & \\
\hline S8I1CN & $\begin{array}{c}\text { Filamentous } \\
\text { Fungus }\end{array}$ & Soil site 8 & Gatineau, QC & 1 & 79.4 & 102.00 & 17.86 & Lecanicillium sp., ${ }^{2,3}$ & KY305085 & \\
\hline GWA18 & $\begin{array}{c}\text { Filamentous } \\
\text { Fungus }\end{array}$ & G.P. White & Ottawa, ON & 1 & 80.9 & 94.82 & 34.76 & & & \\
\hline RFA6P & $\begin{array}{c}\text { Filamentous } \\
\text { Fungus }\end{array}$ & $\begin{array}{c}\text { Foam from Rideau } \\
\text { River } \\
\end{array}$ & Ottawa, ON & $1, \mathrm{~B}, \mathrm{C}$ & 81.2 & 92.95 & 26.13 & & & \\
\hline RW2A1P & $\begin{array}{c}\text { Filamentous } \\
\text { Fungus }\end{array}$ & Rotten wood & Ottawa, ON & $1, \mathrm{~B}, \mathrm{C}$ & 81.7 & 168.31 & 86.00 & Trichoderma sp. $^{2}$ & KY305045 & \\
\hline $\mathrm{OA} 2 \mathrm{~A} 1 \mathrm{M}$ & $\begin{array}{l}\text { Filamentous } \\
\text { Fungus }\end{array}$ & Outdoor air & Ottawa, ON & $1, \mathrm{C}$ & 83.1 & 83.58 & 86.00 & $\begin{array}{l}\text { Trichoderma } \\
\text { atroviride }^{2}\end{array}$ & KY305043 & \\
\hline S9A3R & $\begin{array}{c}\text { Filamentous } \\
\text { Fungus }\end{array}$ & Soil site 9 & Gatineau, QC & $1, \mathrm{~B}, \mathrm{C}$ & 83.4 & 82.42 & 27.50 & $\begin{array}{c}\text { Penicillium } \\
\text { hoeksii }^{2}\end{array}$ & KY305048 & \\
\hline RW1I1Pa & $\begin{array}{c}\text { Filamentous } \\
\text { Fungus }\end{array}$ & Rotten wood & Ottawa, ON & $1, \mathrm{C}$ & 84.2 & 145.67 & 49.01 & $\begin{array}{c}\text { Penicillium } \\
\text { yezoense }^{2}\end{array}$ & KY305038 & KY305091 \\
\hline S9A1CV & $\begin{array}{c}\text { Filamentous } \\
\text { Fungus }\end{array}$ & Soil site 9 & Gatineau, QC & $1, \mathrm{C}$ & 84.3 & 144.92 & 86.00 & $\begin{array}{c}\text { Mortierella } \\
\text { hyalina }\end{array}$ & KY305040 & \\
\hline OA1I4M & $\begin{array}{c}\text { Filamentous } \\
\text { Fungus }\end{array}$ & Outdoor air & Ottawa, ON & $1, \mathrm{~B}, \mathrm{C}$ & 87.4 & 116.39 & 57.15 & $\begin{array}{l}\text { Alternaria } \\
\text { alternata }^{2}\end{array}$ & KY305051 & \\
\hline RW4A1P & $\begin{array}{c}\text { Filamentous } \\
\text { Fungus }\end{array}$ & Rotten wood & Ottawa, ON & 1 & 87.6 & 114.35 & 86.00 & & & \\
\hline S6A1CV & $\begin{array}{c}\text { Filamentous } \\
\text { Fungus }\end{array}$ & Soil site 6 & Ottawa, ON & $1, \mathrm{C}$ & 87.8 & 112.37 & 74.14 & Mortierella gamsii & KY305027 & \\
\hline RW3A1P & $\begin{array}{c}\text { Filamentous } \\
\text { Fungus }\end{array}$ & Rotten wood & Ottawa, ON & $1, \mathrm{C}$ & 87.9 & 111.01 & 86.00 & $\begin{array}{c}\text { Trichoderma } \\
\text { atroviride }^{2} \\
\end{array}$ & KY305039 & \\
\hline RW4A2P & $\begin{array}{c}\text { Filamentous } \\
\text { Fungus }\end{array}$ & Rotten wood & Ottawa, ON & $1, \mathrm{~B}$ & 88.1 & 109.51 & 86.00 & $\begin{array}{c}\text { Trichoderma } \\
\text { atroviride }^{2}\end{array}$ & KY305062 & \\
\hline PCI2P & $\begin{array}{c}\text { Filamentous } \\
\text { Fungus }\end{array}$ & Plate contaminant & Ottawa, ON & $1, \mathrm{C}$ & 88.7 & 56.14 & 15.08 & Oidiodendron $\mathrm{sp}^{2,3}$ & KY305036 & \\
\hline TUB F 945 & $\begin{array}{c}\text { Filamentous } \\
\text { Fungus }\end{array}$ & M.L. Smith & Thailand & 1,A,B,C & 89.5 & 96.35 & 86.00 & $\begin{array}{l}\text { Trichoderma } \\
\text { harzianum }^{2} \\
\end{array}$ & & \\
\hline PCA20P & $\begin{array}{c}\text { Filamentous } \\
\text { Fungus }\end{array}$ & Plate contaminant & Ottawa, ON & $2, \mathrm{C}$ & 90.2 & 48.60 & 13.30 & Oidiodendron $\mathrm{sp}^{2,3}$ & KY305035 & \\
\hline CIB T128 & $\begin{array}{c}\text { Filamentous } \\
\text { Fungus }\end{array}$ & M.L. Smith & Colombia & $2, \mathrm{C}$ & 90.5 & 87.36 & 86.00 & $\begin{array}{l}\text { Trichoderma } \\
\text { harzianum }^{2}\end{array}$ & & \\
\hline RMF-7876 & $\begin{array}{c}\text { Filamentous } \\
\text { Fungus }\end{array}$ & M.L. Smith & Ottawa, ON & 2,B,C & 90.8 & 84.61 & 86.00 & $\begin{array}{l}\text { Trichoderma } \\
\text { harzianum }^{2}\end{array}$ & & \\
\hline S5A1CV & $\begin{array}{c}\text { Filamentous } \\
\text { Fungus }\end{array}$ & Soil site 5 & Ottawa, ON & 2,B,C & 91.1 & 82.03 & 86.00 & $\begin{array}{c}\text { Trichoderma } \\
\text { harzianum }^{2} \\
\end{array}$ & KY305046 & \\
\hline GWI1 & $\begin{array}{c}\text { Filamentous } \\
\text { Fungus }\end{array}$ & G.P. White & Ottawa, ON & 2,B,C & 91.7 & 41.11 & 41.75 & $\begin{array}{c}\text { Penicillium } \\
\text { chrysogenum }^{2}\end{array}$ & KY305050 & KY305088 \\
\hline
\end{tabular}




\begin{tabular}{|c|c|c|c|c|c|c|c|c|c|c|}
\hline S8I2ACS & $\begin{array}{c}\text { Filamentous } \\
\text { Fungus }\end{array}$ & Soil site 8 & Gatineau, QC & 2 & 92.5 & 37.32 & 19.10 & Penicillium sp. ${ }^{2,3}$ & KY305073 & \\
\hline RW1A2P & $\begin{array}{c}\text { Filamentous } \\
\text { Fungus }\end{array}$ & Rotten wood & Ottawa, ON & $2, \mathrm{~B}$ & 92.5 & 69.04 & 86.00 & $\begin{array}{l}\text { Trichoderma } \\
\text { harzianum }^{2}\end{array}$ & KY305061 & \\
\hline OA1I1M & $\begin{array}{c}\text { Filamentous } \\
\text { Fungus }\end{array}$ & Outdoor air & Ottawa, ON & $2, \mathrm{C}$ & 93.6 & 31.95 & 20.98 & Phoma sp. ${ }^{2}$ & KY305031 & \\
\hline S8A1 ACSa & $\begin{array}{c}\text { Filamentous } \\
\text { Fungus }\end{array}$ & Soil site 8 & Gatineau, QC & 2 & 93.7 & 31.00 & 14.31 & $\begin{array}{c}\text { Penicillium } \\
\text { janczewskii }^{2}\end{array}$ & KY305069 & \\
\hline S8A3Cs & $\begin{array}{l}\text { Filamentous } \\
\text { Fungus }\end{array}$ & Soil site 8 & Gatineau, QC & 2 & 95.3 & 23.53 & 20.23 & $\begin{array}{l}\text { Penicillium } \\
\text { canescens }^{2}\end{array}$ & KY305071 & KY305092 \\
\hline GWI4 & $\begin{array}{l}\text { Filamentous } \\
\text { Fungus }\end{array}$ & G.P. White & Ottawa, ON & $2, \mathrm{~B}$ & 95.5 & 41.36 & 45.14 & $\begin{array}{c}\text { Penicillium } \\
\text { chrysogenum }^{2}\end{array}$ & KY305054 & KY305093 \\
\hline S8A1 ACSb & $\begin{array}{c}\text { Filamentous } \\
\text { Fungus }\end{array}$ & Soil site 8 & Gatineau, QC & 2 & 95.7 & 21.34 & 18.22 & $\begin{array}{c}\text { Penicillium } \\
\text { janczewskii }^{2}\end{array}$ & KY305070 & \\
\hline S8A1ACS & $\begin{array}{c}\text { Filamentous } \\
\text { Fungus }\end{array}$ & Soil site 8 & Gatineau, QC & 2 & 95.8 & 21.04 & 26.92 & $\begin{array}{c}\text { Penicillium } \\
\text { yarmokense }^{2}\end{array}$ & KY305077 & KY305090 \\
\hline RW6A1P & $\begin{array}{c}\text { Filamentous } \\
\text { Fungus }\end{array}$ & Rotten wood & Ottawa, ON & $2, \mathrm{C}$ & 95.8 & 38.65 & 28.28 & Boeremia exigua ${ }^{2}$ & KY305037 & \\
\hline S7I1ACS & $\begin{array}{l}\text { Filamentous } \\
\text { Fungus }\end{array}$ & Soil site 7 & Gatineau, QC & $2, \mathrm{~B}, \mathrm{C}$ & 97.5 & 22.69 & 80.17 & $\begin{array}{c}\text { Trichoderma } \\
\text { koningii }^{2}\end{array}$ & KY305047 & \\
\hline S9A2R & $\begin{array}{c}\text { Filamentous } \\
\text { Fungus }\end{array}$ & Soil site 9 & Gatineau, QC & 2 & 98.8 & 5.72 & 40.90 & $\begin{array}{c}\text { Penicillium } \\
\text { hoeksii }^{2}\end{array}$ & KY305076 & \\
\hline S8I2R & $\begin{array}{l}\text { Filamentous } \\
\text { Fungus }\end{array}$ & Soil site 8 & Gatineau, QC & 2 & 99.0 & 5.03 & 20.79 & $\begin{array}{c}\text { Penicillium } \\
\text { janczewskii }^{2}\end{array}$ & KY305074 & \\
\hline TUB F 703 & $\begin{array}{c}\text { Filamentous } \\
\text { Fungus }\end{array}$ & M.L. Smith & India & $2, \mathrm{~B}, \mathrm{C}$ & 99.5 & 4.65 & 86.00 & Trichoderma sp. ${ }^{2}$ & & \\
\hline S8I1R & $\begin{array}{c}\text { Filamentous } \\
\text { Fungus }\end{array}$ & Soil site 8 & Gatineau, QC & 2 & 99.7 & 1.46 & 25.99 & $\begin{array}{c}\text { Penicillium } \\
\text { janczewskii }^{2}\end{array}$ & KY305072 & \\
\hline RW1A6P & $\begin{array}{l}\text { Filamentous } \\
\text { Fungus }\end{array}$ & Rotten wood & Ottawa, ON & 2,B,C & 100.0 & 0.00 & 86.00 & Botrytis cinerea ${ }^{2}$ & KY305044 & \\
\hline $\mathrm{RW} 3 \mathrm{~A} 2 \mathrm{~Pa}$ & $\begin{array}{c}\text { Filamentous } \\
\text { Fungus }\end{array}$ & Rotten wood & Ottawa, ON & $2, \mathrm{~B}$ & 100.0 & 0.00 & 86.00 & & & \\
\hline $\mathrm{S} 3 \mathrm{~A} 2 \mathrm{ACS}$ & $\begin{array}{l}\text { Filamentous } \\
\text { Fungus }\end{array}$ & Soil site 3 & King City, ON & $2, \mathrm{C}$ & 100.0 & 0.00 & 86.00 & Trichoderma sp. ${ }^{2,3}$ & KY305041 & \\
\hline S9A1R & $\begin{array}{l}\text { Filamentous } \\
\text { Fungus }\end{array}$ & Soil site 9 & Gatineau, QC & 2 & 100.0 & 0.00 & 33.10 & Penicillium sp. ${ }^{2,3}$ & KY305075 & KY305089 \\
\hline S2A1LC & Yeast & Soil site 2 & Ottawa, ON & 0 & 24.5 & 390.26 & 6.44 & & & \\
\hline RW3I1b & Yeast & Rotten wood & Ottawa, ON & 0 & 30.0 & 361.99 & 8.97 & & & \\
\hline BY & Yeast & $\begin{array}{c}\text { Dishwasher (G.P. } \\
\text { White) }\end{array}$ & Ottawa, ON & 0 & $34.1^{6}$ & & & $\begin{array}{c}\text { Exophiala } \\
\text { dermatitidis }^{2}\end{array}$ & KY305030 & \\
\hline RFA4P1 & Yeast & $\begin{array}{c}\text { Foam from Rideau } \\
\text { River }\end{array}$ & Ottawa, ON & 0 & $34.1^{6}$ & & & & & \\
\hline RFA8P & Yeast & $\begin{array}{c}\text { Foam from Rideau } \\
\text { River } \\
\end{array}$ & Ottawa, ON & 0 & 40.2 & 550.27 & 30.53 & & & \\
\hline S8I4P & Yeast & Soil site 8 & Gatineau, QC & 0 & 41.7 & 301.29 & 7.32 & & & \\
\hline OA1I5M & Yeast & Outdoor air & Ottawa, ON & 1 & 53.7 & 239.35 & 9.87 & & & \\
\hline
\end{tabular}




\begin{tabular}{|c|c|c|c|c|c|c|c|c|c|}
\hline BWA3P & Yeast & Birch bark & Ottawa, ON & $1, \mathrm{C}$ & 61.9 & 196.93 & 10.03 & $\begin{array}{c}\text { Cystofilobasidium } \\
\text { capitatum }\end{array}$ & KY305024 \\
\hline 9950 & Yeast & M.L. Smith & Ottawa, ON & 1 & 85.0 & 77.62 & 10.76 & Candida utilis & \\
\hline OA2I4M & Yeast & Outdoor air & Ottawa, ON & $1, \mathrm{C}$ & 87.6 & 63.94 & 24.68 & $\begin{array}{c}\text { Aureobasidium } \\
\text { pullulans }\end{array}$ & KY305026 \\
\hline OA1I2M & Yeast & Outdoor air & Ottawa, ON & $1, \mathrm{C}$ & 88.8 & 57.74 & 25.77 & Aureobasidium sp. & KY305025 \\
\hline RW3I1a & Yeast & Rotten wood & Ottawa, ON & $2, \mathrm{C}$ & 93.7 & 32.55 & 15.91 & $\begin{array}{c}\text { Cystofilobasidium } \\
\text { capitatum }\end{array}$ & KY305023 \\
\hline RW1A1P1 & Yeast & Rotten wood & Ottawa, ON & $2, \mathrm{C}$ & 96.9 & 16.00 & 13.04 & $\begin{array}{c}\text { Cystofilobasidium } \\
\text { sp. }\end{array}$ & KY305022 \\
\hline
\end{tabular}

${ }^{1}$ Site1: cattails and soil from a frozen cattail marsh, Site 2: sediment from a thawing pond, Site 3: frozen soil from a mixed forest, Site 4: frozen soil from a Eastern White Cedar forest, Site 5: thawed soil from an ephemeral pond, Site 6: thawed soil from a pine forest, Site 7: thawed and frozen soil from a grass field, Site 8: soil from rock outcropping, Site 9: thawed soil from a maple forest.

${ }^{2}$ Genetic identification was supplemented with morphological examination.

${ }^{3}$ Morphology and/or sequencing data suggests that this is an undescribed species.

${ }^{4}$ Percent inhibition was calculated as $\left(1-\right.$ Area $_{\text {treatment }} /$ Area $\left._{\text {control }}\right) \times 100$. The average $P$. destructans area in no-antagonist controls was $307 \mathrm{~mm}^{2}$ for filamentous fungi and actinobacteria on small plates with 2 stamps of $P$. destructans, $920 \mathrm{~mm}^{2}$ for filamentous fungi on large plates with 3 stamps, and $517 \mathrm{~mm}^{2}$ for bacteria and yeast on small plates with 2 stamps.

${ }^{5}$ Diameter for bacterial and yeast isolates refers to the sum of the width of both streaks through $P$. destructans inoculum.

${ }^{6}$ Day 14 photographs were not available to quantify. Rank is based on a qualitative assessment at the time of bioassay and percent inhibition corresponds to the average percent inhibition for the given rank. 


\section{Appendix 2. Most probable identifications for each volatile compound detected through gas chromatography-mass}

spectrometry analysis of fungal and bacterial antagonists. Antagonists were inoculated on 3-ml PDA slants inside of headspace jars and volatiles were identified. Also listed is the corresponding retention time, molecular formula, match factor (MF), reverse match factor (RMF), probability of match (Prob), and in library (InLib) score for each proposed identification. Italicized entries were tested against $P$. destructans in further assays.

\begin{tabular}{|c|c|c|c|c|c|c|}
\hline Antagonist & $\begin{array}{l}\text { Retention } \\
\text { time (min) }\end{array}$ & Most probable identification & $\begin{array}{l}\text { Molecular } \\
\text { Formula }\end{array}$ & $\begin{array}{l}\text { MF, } \\
\text { RMF }\end{array}$ & Prob & $\begin{array}{l}\text { InLib } \\
\text { Score }\end{array}$ \\
\hline \multirow{5}{*}{$\begin{array}{l}\text { Cystofilobasidium } \\
\text { capitatum RW3I1a }\end{array}$} & 5.76 & Ethanol, 2-(1-methylethoxy)- & $\mathrm{C}_{5} \mathrm{H}_{12} \mathrm{O}_{2}$ & 808,808 & $63.5 \%$ & -240 \\
\hline & 6.23 & 1-Propanol, 2-methyl- & $\mathrm{C}_{4} \mathrm{H}_{10} \mathrm{O}$ & 890,940 & $86.5 \%$ & 191 \\
\hline & 7.93 & 1-Butanol, 2-methyl- & $\mathrm{C}_{5} \mathrm{H}_{12} \mathrm{O}$ & 933,933 & $69.2 \%$ & 113 \\
\hline & 20.83 & 12-Crown-4 & $\mathrm{C}_{8} \mathrm{H}_{16} \mathrm{O}_{4}$ & 588,620 & $25.2 \%$ & -1424 \\
\hline & 22.35 & $\begin{array}{l}\text { Ethaneperoxoic acid, 1-cyano-1-[2-(2-phenyl- } \\
\text { 1,3-dioxolan-2-yl)ethyl]pentyl ester }\end{array}$ & $\mathrm{C}_{19} \mathrm{H}_{25} \mathrm{NO}_{5}$ & 771,884 & $21.1 \%$ & -539 \\
\hline \multirow{4}{*}{ Pantoea sp. OA1I3M } & 5.76 & Hexane, 3-methoxy & $\mathrm{C}_{7} \mathrm{H}_{16} \mathrm{O}$ & 656,782 & $32.1 \%$ & -1103 \\
\hline & 6.22 & 1-Propanol, 2-methyl- & $\mathrm{C}_{4} \mathrm{H}_{10} \mathrm{O}$ & 832,878 & $73.5 \%$ & -161 \\
\hline & 7.93 & 1-Pentanol & $\mathrm{C}_{5} \mathrm{H}_{12} \mathrm{O}$ & 891,893 & $29.1 \%$ & -138 \\
\hline & 9.36 & Urea, ethyl- & $\mathrm{C}_{3} \mathrm{H}_{8} \mathrm{~N}_{2} \mathrm{O}$ & 772,841 & $61.9 \%$ & -324 \\
\hline \multirow{4}{*}{$\begin{array}{l}\text { Pantoea ananatis } \\
\text { RFA4P2 }\end{array}$} & 5.76 & 2-Propanone, 1-(1-methylethoxy)- & $\mathrm{C}_{6} \mathrm{H}_{12} \mathrm{O}_{2}$ & 685,873 & $32.5 \%$ & -941 \\
\hline & 6.23 & Propanoic acid & $\mathrm{C}_{3} \mathrm{H}_{6} \mathrm{O}_{2}$ & 891,891 & $70.5 \%$ & 146 \\
\hline & 7.94 & 1-Pentanol & $\mathrm{C}_{5} \mathrm{H}_{12} \mathrm{O}$ & 939,943 & $52.5 \%$ & 184 \\
\hline & 9.36 & $\begin{array}{l}\text { Morpholine, 4- } \\
{[[(\text { dimethylamino }) \text { thioxomethyl]thio }]-}\end{array}$ & $\mathrm{C}_{7} \mathrm{H}_{14} \mathrm{~N}_{2} \mathrm{OS}_{2}$ & 811,811 & $29.1 \%$ & -371 \\
\hline $\begin{array}{l}\text { Oidiodendron sp. } \\
\text { PCA20P }\end{array}$ & $\mathrm{n} / \mathrm{a}$ & 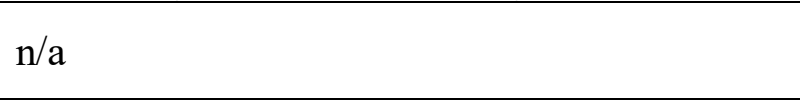 & $\mathrm{n} / \mathrm{a}$ & $\mathrm{n} / \mathrm{a}$ & $\mathrm{n} / \mathrm{a}$ & $\mathrm{n} / \mathrm{a}$ \\
\hline PDA-only control & 5.76 & Acetone, ethyl methyl acetal & $\mathrm{C}_{6} \mathrm{H}_{14} \mathrm{O}_{2}$ & 704,766 & $76.6 \%$ & -190 \\
\hline
\end{tabular}


Appendix 3. Inhibition scores for 36 selected antagonists against different Pseudogymnoascus species. Two strains of $P$. destructans and one strain each of $P$. roseus and P. pannorum were used. Percent inhibition was calculated as $\left(1-\right.$ Area $_{\mathrm{control}} /$ Area experimental $\times 100$. Pseudogymnoascus spp. areas refer to the total area of Pseudogymnoascus spp. 14 days after inoculation. Antagonists were ranked as: $0=$ negligible $(<50 \%)$ inhibition, $1=$ considerable $(50 \%-85 \%)$ inhibition, $2=$ nearly complete/complete $(>85 \%)$ inhibition, relative to a no-antagonist control. Additionally, if applicable, ranks were qualified with: A $=$ growth of the antagonist is limited by Pseudogymnoascus spp., B = the antagonist grew over colonies such that affected Pseudogymnoascus spp. colonies were no longer visible, $\mathrm{C}=$ Pseudogymnoascus spp. colonies were present, but uniformly smaller than in the control plate.

\begin{tabular}{|c|c|c|c|c|c|c|c|c|c|c|c|c|}
\hline \multirow{3}{*}{ Antagonist } & \multicolumn{6}{|c|}{ P. destructans } & \multirow{2}{*}{\multicolumn{3}{|c|}{$\begin{array}{l}\text { P. roseus } \\
\text { S8A2CN }\end{array}$}} & \multirow{2}{*}{\multicolumn{3}{|c|}{$\frac{P . \text { pannorum }}{\text { S8A5ACS1 }}$}} \\
\hline & \multicolumn{3}{|c|}{ SH864 } & \multicolumn{3}{|c|}{ SH991 } & & & & & & \\
\hline & $\begin{array}{c}\text { P. destructans } \\
\text { Area }\left(\mathrm{mm}^{2}\right)\end{array}$ & $\begin{array}{c}\text { Percent } \\
\text { Inhibition }\end{array}$ & Rank & $\begin{array}{c}\text { P. destructans } \\
\text { Area }\left(\mathrm{mm}^{2}\right)\end{array}$ & $\begin{array}{c}\text { Percent } \\
\text { Inhibition }\end{array}$ & Rank & $\begin{array}{c}P . \text { roseus } \\
\text { Area }\left(\mathrm{mm}^{2}\right)\end{array}$ & $\begin{array}{c}\text { Percent } \\
\text { Inhibition }\end{array}$ & Rank & $\begin{array}{l}\text { P. pannorum } \\
\text { Area }\left(\mathrm{mm}^{2}\right)\end{array}$ & $\begin{array}{c}\text { Percent } \\
\text { Inhibition }\end{array}$ & Rank \\
\hline 14807 & 5.62 & 98.9 & $2 \mathrm{C}$ & 72.03 & 87.8 & $2 \mathrm{C}$ & 805.96 & 22.2 & $0 \mathrm{~A}$ & 865.09 & 19.7 & $0 \mathrm{~A}$ \\
\hline APCI2P & 0.00 & 100.0 & 2 & 0.00 & 100.0 & 2 & 241.99 & 76.6 & 1 & 487.66 & 54.7 & 1 \\
\hline B-14324 & 0.60 & 99.9 & 2 & 4.74 & 99.2 & 2 & 729.72 & 29.5 & $0 \mathrm{~A}$ & 538.86 & 50.0 & $0 \mathrm{~A}$ \\
\hline B9-5 & 35.94 & 93.3 & 2 & 68.42 & 88.4 & 2 & 806.20 & 22.1 & 0 & 657.35 & 39.0 & $0 \mathrm{~A}$ \\
\hline GWA3a & 2.23 & 99.6 & 2 & 5.00 & 99.2 & 2 & 601.37 & 41.9 & 0 & 468.99 & 56.5 & 1 \\
\hline GWA3c & 0.00 & 100.0 & 2 & 5.99 & 99.0 & 2 & 468.12 & 54.8 & 1 & 536.53 & 50.2 & 1 \\
\hline IC10 & 58.16 & 89.1 & 2 & 92.21 & 84.4 & 1 & 710.87 & 31.3 & 0 & 527.38 & 51.0 & $1 \mathrm{~A}$ \\
\hline M9-14 & 42.72 & 92.0 & 2 & 122.17 & 79.3 & 1 & 814.32 & 21.4 & 0 & 571.57 & 46.9 & 0 \\
\hline M9-2 & 48.10 & 91.0 & 2 & 140.63 & 76.2 & 1 & 831.85 & 19.7 & 0 & 687.24 & 36.2 & 0 \\
\hline M9-4 & 42.48 & 92.1 & 2 & 48.48 & 91.8 & 2 & 669.81 & 35.3 & $0 \mathrm{~A}$ & 739.85 & 31.3 & $0 \mathrm{~A}$ \\
\hline M9-9 & 78.31 & 85.4 & 2 & 77.83 & 86.8 & 2 & 402.49 & 61.1 & $1 \mathrm{~A}$ & 698.67 & 35.1 & 0 \\
\hline OA1I3M & 7.08 & 98.7 & 2 & 22.25 & 96.2 & $2 \mathrm{C}$ & 496.67 & 52.0 & 1 & 459.50 & 57.3 & 1 \\
\hline PCA13P & 187.80 & 64.9 & 1 & 329.35 & 44.3 & 0 & 893.31 & 13.7 & 0 & 967.29 & 10.2 & 0 \\
\hline PCA20P & 24.16 & 95.5 & 2 & 29.80 & 95.0 & 2 & 892.63 & 13.8 & 0 & 945.29 & 12.2 & 0 \\
\hline PCI2P & 53.23 & 90.0 & 2 & 72.94 & 87.7 & 2 & 1018.52 & 1.6 & 0 & 922.27 & 14.4 & 0 \\
\hline RFA4P2 & 20.25 & 96.2 & $2 \mathrm{C}$ & 6.72 & 98.9 & $2 \mathrm{C}$ & 617.23 & 40.4 & 0 & 704.14 & 34.6 & 0 \\
\hline RW1A1P1 & 54.60 & 89.8 & $1 \mathrm{C}$ & 78.04 & 86.8 & $2 \mathrm{C}$ & 698.48 & 32.5 & 0 & 791.66 & 26.5 & 0 \\
\hline RW1A2P & 36.73 & 95.4 & $2 \mathrm{C}$ & 139.59 & 84.3 & $1 \mathrm{C}$ & 1193.26 & 23.2 & $0 \mathrm{~A}$ & 1553.52 & 3.8 & $0 \mathrm{~A}$ \\
\hline RW3A2Pa & 0.00 & 100.0 & 2 & 0.00 & 100.0 & 2 & 0.00 & 100.0 & 2 & 728.03 & 54.9 & $1 \mathrm{~A}$ \\
\hline RW3I1a & 19.31 & 96.4 & $2 \mathrm{C}$ & 39.80 & 93.3 & $2 \mathrm{C}$ & 595.26 & 42.5 & 0 & 595.90 & 44.7 & 0 \\
\hline
\end{tabular}




\begin{tabular}{|c|c|c|c|c|c|c|c|c|c|c|c|c|}
\hline \multirow{3}{*}{ Antagonist } & \multicolumn{6}{|c|}{ P. destructans } & \multirow{2}{*}{\multicolumn{3}{|c|}{$\begin{array}{r}P . \text { roseus } \\
\text { S8A2CN } \\
\end{array}$}} & \multirow{2}{*}{\multicolumn{3}{|c|}{$\begin{array}{c}\text { P. pannorum } \\
\text { S8A5ACS1 }\end{array}$}} \\
\hline & \multicolumn{3}{|c|}{$\begin{array}{r}\text { SH864 } \\
\end{array}$} & \multicolumn{3}{|c|}{ SH991 } & & & & & & \\
\hline & $\begin{array}{l}\text { P. destructans } \\
\text { Area }\left(\mathrm{mm}^{2}\right)\end{array}$ & $\begin{array}{l}\text { Percent } \\
\text { Inhibition }\end{array}$ & Rank & $\begin{array}{l}\text { P. destructans } \\
\text { Area }\left(\mathrm{mm}^{2}\right)\end{array}$ & $\begin{array}{c}\text { Percent } \\
\text { Inhibition }\end{array}$ & Rank & $\begin{array}{c}P . \operatorname{roseus} \\
\text { Area }\left(\mathrm{mm}^{2}\right)\end{array}$ & $\begin{array}{c}\text { Percent } \\
\text { Inhibition }\end{array}$ & Rank & $\begin{array}{l}\text { P. pannorum } \\
\text { Area }\left(\mathrm{mm}^{2}\right)\end{array}$ & $\begin{array}{c}\text { Percent } \\
\text { Inhibition }\end{array}$ & Rank \\
\hline RW4A2P & 0.00 & 100.0 & 2B & 0.00 & 100.0 & $2 \mathrm{~B}$ & 506.51 & 67.4 & 1 & 490.43 & 69.6 & 1 \\
\hline RW6A1P & 3.70 & 99.5 & 2 & 10.60 & 98.8 & $2 \mathrm{C}$ & 1258.45 & 19.0 & 0 & 1194.88 & 26.0 & 0 \\
\hline S4I1ACS & 8.91 & 98.3 & 2 & 11.18 & 98.1 & 2 & 487.40 & 52.9 & 1 & 531.98 & 50.6 & 1 \\
\hline S5A2LC & 4.17 & 99.2 & 2 & 19.98 & 96.6 & 2 & 782.98 & 24.4 & 0 & 581.96 & 46.0 & 0 \\
\hline S6A3ACS & 0.00 & 100.0 & 2 & 0.00 & 100.0 & 2 & 493.51 & 52.3 & 1 & 647.11 & 39.9 & 0 \\
\hline S8A1ACS & 4.24 & 99.2 & 2 & 28.10 & 95.2 & 2 & 805.08 & 22.2 & 0 & 863.74 & 19.8 & 0 \\
\hline S8A1ACSa & 1.75 & 99.7 & 2 & 11.67 & 98.0 & 2 & 887.94 & 14.2 & 0 & 774.39 & 28.1 & 0 \\
\hline S8A1ACSb & 1.81 & 99.7 & 2 & 15.34 & 97.4 & 2 & 797.24 & 23.0 & 0 & 719.64 & 33.2 & 0 \\
\hline S8A1Cs1b & 0.00 & 100.0 & 2 & 0.00 & 100.0 & 2 & 154.77 & 85.1 & 2 & 158.72 & 85.3 & 2 \\
\hline S8A3Cs & 10.64 & 98.0 & 2 & 45.19 & 92.4 & 2 & 365.62 & 64.7 & 1 & 861.00 & 20.1 & 0 \\
\hline $\mathrm{S} 8 \mathrm{~A} 4 \mathrm{Cs}$ & 0.00 & 100.0 & 2 & 0.00 & 100.0 & 2 & 481.33 & 53.5 & 1 & 585.57 & 45.6 & 0 \\
\hline S8I1R & 2.78 & 99.5 & 2 & 7.82 & 98.7 & 2 & 738.41 & 28.7 & 0 & 149.85 & 86.1 & 2 \\
\hline S8I2ACS & 31.82 & 94.1 & 2 & 21.12 & 96.4 & 2 & 510.14 & 50.7 & 1 & 549.07 & 49.0 & 0 \\
\hline S8I2R & 2.31 & 99.6 & 2 & 16.82 & 97.2 & 2 & 942.53 & 9.0 & 0 & 769.21 & 28.6 & 0 \\
\hline S9A1R & 0.00 & 100.0 & 2 & 5.78 & 99.0 & 2 & 752.16 & 27.4 & 0 & 862.07 & 20.0 & 0 \\
\hline S9A2R & 41.77 & 92.2 & 1 & 149.04 & 74.8 & 1 & 1112.22 & -7.4 & 0 & 448.39 & 58.4 & 1 \\
\hline
\end{tabular}


Appendix 4. Inhibitory concentrations for the filtered, spent media from each of 35 antagonist cultures. Antagonists were grown at $13 \pm 1{ }^{\circ} \mathrm{C}$ for 28 days and screened against three strains of Pseudogymnoascus destructans and one strain each of $P$. roseus, P. pannorum, and Saccharomyces cerevisiae. Inhibitory concentrations were recorded after 14 days of Pseudogymnoascus growth or 3 days of $S$. cerevisiae growth and are expressed relative to the original concentration of the day 28 antagonist medium. NI indicates that complete inhibition was not evident even at highest concentration of $2.5 \times$ antagonist medium and ND indicates that inhibitory concentration was not assessed.

\begin{tabular}{|c|c|c|c|c|c|c|}
\hline \multirow[b]{2}{*}{ Antagonist } & \multicolumn{3}{|c|}{ P. destructans } & \multirow{2}{*}{$\begin{array}{l}\text { P. roseus } \\
\text { S8A2CN }\end{array}$} & \multirow{2}{*}{$\begin{array}{c}\text { P. pannorum } \\
\text { S8A5ACS1 }\end{array}$} & \multirow{2}{*}{$\frac{\text { S. cerevisiae }}{\mathbf{S 2 8 8 C}}$} \\
\hline & US15 & SH864 & SH991 & & & \\
\hline 14807 & NI & 2.5 & $\mathrm{NI}$ & 2.5 & $\mathrm{NI}$ & $\mathrm{NI}$ \\
\hline APCI1P & 2.5 & NI & NI & NI & NI & NI \\
\hline APCI2P & 0.08 & 0.08 & 0.08 & 0.16 & 0.16 & ND \\
\hline BWA3P & NI & NI & NI & NI & NI & ND \\
\hline GWA3a & $\mathrm{NI}$ & NI & NI & NI & NI & NI \\
\hline GWA3c & NI & NI & NI & NI & NI & ND \\
\hline OA1I1M & 0.08 & 0.08 & 0.08 & NI & NI & NI \\
\hline OA1I3M & NI & 2.5 & NI & 2.5 & NI & NI \\
\hline OA1I5Mb & NI & NI & NI & NI & NI & $\mathrm{NI}$ \\
\hline PCA13P & NI & NI & NI & NI & NI & ND \\
\hline PCA20P & $\mathrm{NI}$ & NI & $\mathrm{NI}$ & $\mathrm{NI}$ & NI & ND \\
\hline PCA22M & $\mathrm{NI}$ & NI & NI & NI & NI & ND \\
\hline PCA5P & 0.31 & 0.08 & 0.16 & 2.5 & NI & NI \\
\hline PCI2P & NI & NI & NI & NI & NI & ND \\
\hline RFA4P2 & NI & 1.25 & 2.5 & 1.25 & NI & ND \\
\hline RFA6P & 0.63 & 0.31 & 0.31 & NI & NI & ND \\
\hline RW1A1P1 & NI & NI & NI & NI & NI & ND \\
\hline RW1A2P & 0.63 & 0.16 & 0.16 & 2.5 & NI & NI \\
\hline RW3A2Pa & 0.01 & $<0.005$ & 0.01 & 0.63 & 1.25 & ND \\
\hline RW3I1a & NI & NI & NI & NI & NI & NI \\
\hline RW4A2P & 0.63 & 0.16 & 0.31 & 1.25 & 1.25 & 2.5 \\
\hline S4I1ACS & NI & NI & NI & NI & NI & ND \\
\hline S5A2LC & NI & NI & NI & NI & NI & NI \\
\hline S6A3ACS & $\mathrm{NI}$ & NI & $\mathrm{NI}$ & NI & NI & NI \\
\hline S8A1ACS & NI & NI & NI & $\mathrm{NI}$ & NI & ND \\
\hline S8A1ACSa & 0.63 & 0.63 & 0.63 & NI & NI & ND \\
\hline $\mathrm{S} 8 \mathrm{~A} 1 \mathrm{ACSb}$ & NI & NI & NI & NI & NI & NI \\
\hline $\mathrm{S} 8 \mathrm{~A} 1 \mathrm{Cs} 1 \mathrm{~b}$ & NI & $\mathrm{NI}$ & NI & NI & NI & NI \\
\hline S8A4Cs & 0.31 & 0.16 & 0.16 & NI & NI & $\mathrm{NI}$ \\
\hline $\mathrm{S} 8 \mathrm{I} 1 \mathrm{CN}$ & 2.5 & 1.25 & 1.25 & NI & NI & NI \\
\hline S8I1R & 2.5 & NI & NI & NI & NI & $\mathrm{NI}$ \\
\hline S8I2ACS & 1.25 & 0.63 & 0.63 & 2.5 & NI & NI \\
\hline S8I2R & NI & 2.5 & NI & NI & NI & NI \\
\hline S9A1R & 2.5 & 1.25 & 2.5 & NI & NI & ND \\
\hline S9A2R & NI & NI & NI & NI & NI & ND \\
\hline
\end{tabular}


Appendix 5. Inhibition of plant pathogens by cell-free broth from different microbial antagonistic strains. Numbers reflect the concentration, relative to the original broth, required for complete inhibition of the pathogen, and $>2.5$ reflects that no inhibition was seen at the highest concentration. Day indicates how many days the pathogens grew before recording the growth and ND indicates that inhibition was not assessed.

\begin{tabular}{|c|c|c|c|c|c|}
\hline Broth antagonist strain & V. dahliae 176 & $\begin{array}{c}\text { B. cinerea } \\
231370 \\
\end{array}$ & $\begin{array}{c}\text { B. cinerea } \\
189076 \\
\end{array}$ & $\begin{array}{c}\text { A. solani } \\
229590\end{array}$ & $\begin{array}{c}\text { C. parasitica } \\
\text { EP155 }\end{array}$ \\
\hline Day & 3 & 3 & 5 & 3 & 5 \\
\hline Alternaria alternata OA1I4M & 0.625 & $>2.5$ & $>2.5$ & $>2.5$ & $>2.5$ \\
\hline Aureobasidium pullulans $\mathrm{OA} 2 \mathrm{I} 4 \mathrm{M}$ & $>2.5$ & $>2.5$ & $>2.5$ & $>2.5$ & $>2.5$ \\
\hline Bacillus sp. 14807 & $>2.5$ & 0.078 & $>2.5$ & 0.313 & 0.010 \\
\hline Bacillus sp. 55407 & $>2.5$ & 0.625 & $>2.5$ & 0.625 & 0.156 \\
\hline Bacillus sp. APCI1P & $>2.5$ & 0.625 & $>2.5$ & 0.625 & 0.313 \\
\hline Bacillus sp. B-14324 & $>2.5$ & 0.313 & $>2.5$ & 0.625 & 0.156 \\
\hline Bacillus subtilis S9A1Cs1 & $>2.5$ & $>2.5$ & 0.156 & $>2.5$ & 0.156 \\
\hline Boeremia exigua RW6A1P & $>2.5$ & $>2.5$ & $>2.5$ & $>2.5$ & $>2.5$ \\
\hline Elsinoë brasiliensis CABI 395825 & $>2.5$ & $>2.5$ & $>2.5$ & $>2.5$ & $>2.5$ \\
\hline Lecanicillium sp. S8I1CN & $<0.002$ & $<0.002$ & $<0.002$ & $>2.5$ & $<0.002$ \\
\hline Paecilomyces inflatus PCA5P & $>2.5$ & $>2.5$ & $>2.5$ & $>2.5$ & $>2.5$ \\
\hline Pantoea ananatis RFA4P2 & $>2.5$ & 0.313 & $>2.5$ & 0.625 & 0.313 \\
\hline Pantoea sp. OA1I3M & $>2.5$ & 0.625 & $>2.5$ & 0.625 & 0.313 \\
\hline Penicillium canescens S8A3CS & 0.156 & $>2.5$ & 0.156 & 1.250 & 1.250 \\
\hline Penicillium janczewskii S8A1ACSa & $>2.5$ & $>2.5$ & $>2.5$ & $>2.5$ & $>2.5$ \\
\hline Penicillium janczewskii S8I2R & $>2.5$ & $>2.5$ & $>2.5$ & $>2.5$ & 1.250 \\
\hline Penicillium sp. S8I2ACS & 0.156 & $>2.5$ & $>2.5$ & 1.250 & 0.078 \\
\hline Penicillium sp. S9A1R & $>2.5$ & $>2.5$ & $>2.5$ & $>2.5$ & $>2.5$ \\
\hline Penicillium yarmokense S8A1ACS & 0.313 & 1.250 & 1.250 & $>2.5$ & 1.250 \\
\hline Phoma sp. OA1I1M & $>2.5$ & $>2.5$ & $>2.5$ & $>2.5$ & $>2.5$ \\
\hline Pseudogymnoascus roseus S8A2CN & $>2.5$ & $>2.5$ & $>2.5$ & $>2.5$ & $>2.5$ \\
\hline Pseudomonas sp. APCI2P & $>2.5$ & 0.625 & $>2.5$ & 0.625 & 0.156 \\
\hline Ramularia vizellae OA1I5Mb & $>2.5$ & $>2.5$ & $>2.5$ & $>2.5$ & $>2.5$ \\
\hline RFA6P & 0.625 & 0.313 & 0.313 & $>2.5$ & 0.625 \\
\hline $\mathrm{RW} 3 \mathrm{~A} 2 \mathrm{~Pa}$ & 0.078 & 0.625 & 0.156 & 0.156 & 0.625 \\
\hline $\mathrm{S} 4 \mathrm{~A} 2 \mathrm{P}$ & $>2.5$ & $>2.5$ & $>2.5$ & $>2.5$ & $>2.5$ \\
\hline S8I1ACS & 0.156 & $>2.5$ & $>2.5$ & $>2.5$ & $>2.5$ \\
\hline Simplicillium sp. GWA12 & $>2.5$ & $>2.5$ & 0.156 & $>2.5$ & 1.250 \\
\hline $\begin{array}{l}\text { Sphingobium sp. S8A4Cs } \\
\text { Streptomyces laeteviolaceus }\end{array}$ & $>2.5$ & $>2.5$ & $>2.5$ & $>2.5$ & 1.250 \\
\hline S6A3ACS & $>2.5$ & $>2.5$ & $>2.5$ & $>2.5$ & $>2.5$ \\
\hline Trichoderma atroviride RW4A2P & 0.156 & 0.156 & 0.078 & $>2.5$ & 0.078 \\
\hline Trichoderma harzianum RW1A2P & 0.625 & $>2.5$ & 0.625 & $>2.5$ & 1.250 \\
\hline Trichoderma sp. S3A2ACS & 0.625 & 0.625 & 0.313 & $>2.5$ & 0.625 \\
\hline $10 \times \mathrm{LB}$ & $>2.5$ & $>2.5$ & $>2.5$ & $>2.5$ & 1.250 \\
\hline $10 \times \mathrm{PDB}$ & $>2.5$ & $>2.5$ & $>2.5$ & $>2.5$ & $>2.5$ \\
\hline $2 \mathrm{mg} \mathrm{ml}^{-1}$ Hygromycin B & $<0.002$ & $<0.002$ & 0.156 & $<0.002$ & $<0.002$ \\
\hline
\end{tabular}




\begin{tabular}{|c|c|c|c|c|c|}
\hline Broth antagonist strain & $\begin{array}{c}\text { F. avenaceum } \\
\text { RW1A5P }\end{array}$ & $\begin{array}{l}\text { B. cinerea } \\
\text { RW1A6P }\end{array}$ & $\begin{array}{c}\text { S. sclerotiorum } \\
241671 \\
\end{array}$ & $\begin{array}{l}\text { A. alternata } \\
196949\end{array}$ & $\begin{array}{c}\text { P. syringae } \\
4326\end{array}$ \\
\hline Day & 3 & 3 & 3 & 3 & 3 \\
\hline Alternaria alternata OA1I4M & $>2.5$ & $>2.5$ & $>2.5$ & $>2.5$ & $>2.5$ \\
\hline Aureobasidium pullulans OA2I4M & $>2.5$ & $>2.5$ & $>2.5$ & $>2.5$ & $>2.5$ \\
\hline Bacillus sp. 14807 & $>2.5$ & 0.039 & 0.313 & $>2.5$ & 0.625 \\
\hline Bacillus sp. 55407 & $>2.5$ & $>2.5$ & 0.313 & $>2.5$ & 0.625 \\
\hline Bacillus sp. APCI1P & $>2.5$ & $>2.5$ & 0.625 & $>2.5$ & 0.625 \\
\hline Bacillus sp. B-14324 & $>2.5$ & 0.625 & 0.313 & $>2.5$ & 0.625 \\
\hline Bacillus subtilis S9A1Cs1 & $>2.5$ & $>2.5$ & $>2.5$ & $>2.5$ & $>2.5$ \\
\hline Boeremia exigua RW6A1P & $>2.5$ & $>2.5$ & $>2.5$ & $>2.5$ & 0.625 \\
\hline Elsinoë brasiliensis CABI 395825 & $>2.5$ & $>2.5$ & $>2.5$ & $>2.5$ & $>2.5$ \\
\hline Lecanicillium sp. S8I1CN & 0.156 & $<0.002$ & 0.005 & 0.010 & 0.156 \\
\hline Paecilomyces inflatus PCA5P & $>2.5$ & $>2.5$ & $>2.5$ & $>2.5$ & $>2.5$ \\
\hline Pantoea ananatis RFA4P2 & $>2.5$ & 0.625 & 0.313 & $>2.5$ & 0.625 \\
\hline Pantoea sp. OA1I3M & $>2.5$ & $>2.5$ & 0.625 & $>2.5$ & 0.625 \\
\hline Penicillium canescens S8A3CS & 0.625 & 1.250 & 1.250 & 1.250 & 0.156 \\
\hline Penicillium janczewskii S8A1ACSa & $>2.5$ & $>2.5$ & $>2.5$ & $>2.5$ & $>2.5$ \\
\hline Penicillium janczewskii S8I2R & $>2.5$ & $>2.5$ & $>2.5$ & $>2.5$ & $>2.5$ \\
\hline Penicillium sp. S8I2ACS & $>2.5$ & $>2.5$ & $>2.5$ & 1.250 & 1.250 \\
\hline Penicillium sp. S9A1R & $>2.5$ & $>2.5$ & $>2.5$ & $>2.5$ & 1.250 \\
\hline Penicillium yarmokense S8A1ACS & 0.625 & $>2.5$ & 1.250 & 1.250 & 0.313 \\
\hline Phoma sp. OA1I1M & $>2.5$ & $>2.5$ & $>2.5$ & $>2.5$ & 0.625 \\
\hline Pseudogymnoascus roseus $\mathrm{S} 8 \mathrm{~A} 2 \mathrm{CN}$ & $>2.5$ & $>2.5$ & $>2.5$ & $>2.5$ & $>2.5$ \\
\hline Pseudomonas sp. APCI2P & $>2.5$ & 0.625 & 0.625 & $>2.5$ & 0.625 \\
\hline Ramularia vizellae OA1I5Mb & $>2.5$ & $>2.5$ & $>2.5$ & $>2.5$ & $>2.5$ \\
\hline RFA6P & $>2.5$ & 0.313 & 0.625 & $>2.5$ & 0.625 \\
\hline RW3A2Pa & 0.313 & 0.156 & 0.156 & 0.625 & 0.078 \\
\hline S4A2P & $>2.5$ & $>2.5$ & $>2.5$ & $>2.5$ & 0.625 \\
\hline S8I1ACS & $>2.5$ & $>2.5$ & $>2.5$ & $>2.5$ & 0.625 \\
\hline Simplicillium sp. GWA12 & $>2.5$ & $>2.5$ & $>2.5$ & $>2.5$ & $>2.5$ \\
\hline $\begin{array}{l}\text { Sphingobium sp. S8A4Cs } \\
\text { Streptomyces laeteviolaceus }\end{array}$ & $>2.5$ & $>2.5$ & $>2.5$ & $>2.5$ & 0.625 \\
\hline S6A3ACS & $>2.5$ & $>2.5$ & $>2.5$ & $>2.5$ & 0.625 \\
\hline Trichoderma atroviride RW4A2P & 0.625 & 0.156 & 0.313 & $>2.5$ & 0.078 \\
\hline Trichoderma harzianum RW1A2P & $>2.5$ & $>2.5$ & 0.625 & $>2.5$ & 1.250 \\
\hline Trichoderma sp. S3A2ACS & $>2.5$ & 0.625 & $>2.5$ & $>2.5$ & 0.625 \\
\hline $10 \times \mathrm{LB}$ & $>2.5$ & $>2.5$ & $>2.5$ & $>2.5$ & 0.625 \\
\hline $10 \times \mathrm{PDB}$ & $>2.5$ & $>2.5$ & $>2.5$ & $>2.5$ & $>2.5$ \\
\hline $2 \mathrm{mg} \mathrm{ml}^{-1}$ Hygromycin B & $<0.002$ & $<0.002$ & $<0.002$ & $<0.002$ & 0.020 \\
\hline
\end{tabular}




\begin{tabular}{|c|c|c|c|c|c|c|}
\hline Broth antagonist strain & $\begin{array}{c}C . \\
\text { parasitica } \\
\text { P88-8 }\end{array}$ & $\begin{array}{c}E . \\
\text { brasiliensis } \\
\mathbf{3 9 5 8 2 5} \\
\end{array}$ & $\begin{array}{c}C . \\
\text { parasitica } \\
\text { P74-3 } \\
\end{array}$ & $\begin{array}{c}F . \\
\text { oxysporum } \\
215464 \\
\end{array}$ & $\begin{array}{c}P . \\
\text { syringae } \\
\text { Pst } 3000\end{array}$ & $\begin{array}{c}A . \\
\text { solani } \\
229596\end{array}$ \\
\hline Day & 5 & 5 & 6 & 3 & 3 & 5 \\
\hline Alternaria alternata OA1I4M & $>2.5$ & $>2.5$ & $>2.5$ & $>2.5$ & ND & ND \\
\hline Aureobasidium pullulans OA2I4M & $>2.5$ & $>2.5$ & $>2.5$ & $>2.5$ & 0.313 & 1.250 \\
\hline Bacillus sp. 14807 & 0.039 & 0.313 & 0.010 & $>2.5$ & $>2.5$ & 0.313 \\
\hline Bacillus sp. 55407 & 0.156 & 0.313 & 0.156 & $>2.5$ & $>2.5$ & 0.156 \\
\hline Bacillus sp. APCI1P & 0.156 & 0.313 & 0.156 & $>2.5$ & $>2.5$ & $>2.5$ \\
\hline Bacillus sp. B-14324 & 0.156 & 0.313 & 0.020 & $>2.5$ & 0.625 & 0.313 \\
\hline Bacillus subtilis S9A1Cs1 & 0.078 & 0.313 & 0.078 & $>2.5$ & $>2.5$ & 0.313 \\
\hline Boeremia exigua RW6A1P & $>2.5$ & $>2.5$ & $>2.5$ & $>2.5$ & 1.250 & $>2.5$ \\
\hline Elsinoë brasiliensis CABI 395825 & $>2.5$ & $>2.5$ & 1.250 & $>2.5$ & $>2.5$ & $>2.5$ \\
\hline Lecanicillium sp. S8I1CN & $<0.002$ & $<0.002$ & $<0.002$ & $>2.5$ & 0.313 & $<0.002$ \\
\hline Paecilomyces inflatus PCA5P & $>2.5$ & $>2.5$ & $>2.5$ & $>2.5$ & 0.625 & $>2.5$ \\
\hline Pantoea ananatis RFA4P2 & 0.313 & 0.313 & 0.156 & $>2.5$ & $>2.5$ & 0.313 \\
\hline Pantoea sp. OA1I3M & 0.313 & 0.313 & 0.156 & $>2.5$ & $>2.5$ & 0.625 \\
\hline Penicillium canescens S8A3CS & 0.625 & 1.250 & 0.625 & 1.250 & $>2.5$ & 1.250 \\
\hline Penicillium janczewskii S8A1ACSa & $>2.5$ & $>2.5$ & $>2.5$ & $>2.5$ & 1.250 & $>2.5$ \\
\hline Penicillium janczewskii S8I2R & $>2.5$ & $>2.5$ & $>2.5$ & $>2.5$ & $>2.5$ & $>2.5$ \\
\hline Penicillium sp. S8I2ACS & 0.078 & 0.156 & 0.078 & $>2.5$ & 0.625 & 0.625 \\
\hline Penicillium sp. S9A1R & $>2.5$ & $>2.5$ & $>2.5$ & $>2.5$ & 0.625 & $>2.5$ \\
\hline Penicillium yarmokense S8A1ACS & 1.250 & 1.250 & 1.250 & 1.250 & 0.625 & 1.250 \\
\hline Phoma sp. OA1I1M & $>2.5$ & $>2.5$ & $>2.5$ & 1.250 & 1.250 & $>2.5$ \\
\hline Pseudogymnoascus roseus $\mathrm{S} 8 \mathrm{~A} 2 \mathrm{CN}$ & $>2.5$ & $>2.5$ & 1.250 & $>2.5$ & $>2.5$ & $>2.5$ \\
\hline Pseudomonas sp. APCI2P & 0.156 & 0.313 & 0.078 & $>2.5$ & $>2.5$ & 1.250 \\
\hline Ramularia vizellae OA1I5Mb & $>2.5$ & $>2.5$ & $>2.5$ & $>2.5$ & $>2.5$ & $>2.5$ \\
\hline RFA6P & 0.039 & 0.625 & 0.020 & 1.250 & 0.625 & 0.625 \\
\hline RW3A2Pa & 0.625 & 0.156 & 0.625 & 0.625 & 0.078 & $>2.5$ \\
\hline $\mathrm{S} 4 \mathrm{~A} 2 \mathrm{P}$ & $>2.5$ & $>2.5$ & $>2.5$ & $>2.5$ & 1.250 & $>2.5$ \\
\hline S8I1ACS & $>2.5$ & $>2.5$ & 0.625 & $>2.5$ & 0.625 & $>2.5$ \\
\hline Simplicillium sp. GWA12 & $>2.5$ & 1.250 & $>2.5$ & $>2.5$ & 0.020 & 0.625 \\
\hline $\begin{array}{l}\text { Sphingobium sp. S8A4Cs } \\
\text { Streptomyces laeteviolaceus }\end{array}$ & 1.250 & 1.250 & 0.625 & $>2.5$ & $>2.5$ & 1.250 \\
\hline S6A3ACS & $>2.5$ & $>2.5$ & $>2.5$ & $>2.5$ & 1.250 & $>2.5$ \\
\hline Trichoderma atroviride RW4A2P & 0.078 & 0.156 & 0.078 & $>2.5$ & 0.156 & 0.625 \\
\hline Trichoderma harzianum RW1A2P & 1.250 & $>2.5$ & 1.250 & $>2.5$ & 0.625 & 0.625 \\
\hline Trichoderma sp. S3A2ACS & 0.625 & 0.625 & 0.625 & $>2.5$ & 0.039 & 0.625 \\
\hline $10 \times \mathrm{LB}$ & 1.250 & $>2.5$ & $>2.5$ & $>2.5$ & $>2.5$ & 0.625 \\
\hline $10 \times \mathrm{PDB}$ & $>2.5$ & $>2.5$ & $>2.5$ & $>2.5$ & 1.250 & $>2.5$ \\
\hline $2 \mathrm{mg} \mathrm{m}^{-1}$ Hygromycin B & $<0.002$ & $<0.002$ & $<0.002$ & 0.005 & 0.156 & $<0.002$ \\
\hline
\end{tabular}




\section{References}

Abe, F. and H. Iida. 2003. Pressure-induced differential regulation of the two tryptophan permeases Tat 1 and Tat 2 by ubiquitin ligase Rsp 5 and its binding proteins, Bul1 and Bul2. Molecular and Cellular Biology, 23: 7566-84.

Ahmadi, N., K. Khosravi-Darani, and A.M. Mortazavian. 2016. An overview of biotechnological production of propionic acid: From upstream to downstream processes. Electronic Journal of Biotechnology, 28: 67-75.

Alabouvette, C. and C. Steinburg. 1995. Suppressiveness of soils to invading micro-organisms. In: Hokkanen, H.M.T. and J.M. Lynch (eds). Biological Control: Benefits and Risks. New York: Cambridge University Press.

Andrews, N.W., P.E. de Almeida, and M. Corrotte. 2014. Damage control: Cellular mechanisms of plasma membrane repair. Trends in Cellular Biology, 24: 734-42.

Ashe, M.P., J.W. Slaven, S.K. De Long, S. Ibrahimo, and A.B. Sachs. 2001. A novel eIF2Bdependent mechanism of translational control in yeast as a response to fusel alcohols. The EMBO Journal, 20: 6464-74.

Babst, M. 2014. Quality control at the plasma membrane: One mechanism does not fit all. Journal of Cell Biology, 205: 11-20.

Barbet, N.C., U. Schneider, S.B. Helliwell, I. Stansfield, M.F. Tuite, and M.N. Hall. 1996. TOR controls translation initiation and early G1 progression in yeast. Molecular Biology of the Cell, 7: 25-42.

Barnum, K.J. and M.J. O'Connell. 2014. Cell cycle regulation by checkpoints. Methods in Molecular Biology, 1170: 29-40.

Bertoli, C., J.M. Skotheim, R.A.M. de Bruin. 2013. Control of cell cycle transcription during G1 and S phases. Nature Reviews Molecular Cell Biology, 14: 518-28.

Bhatia, S.K. and Y.-H. Yang. 2017. Microbial production of volatile fatty acids: current status and future perspectives. Reviews in Environmental Science and Biotechnology, 16: 327-45.

Bidochka, M.J., R.J. St Leger, A. Stuart, and K. Gowanlock. 1999. Nuclear rDNA phylogeny in the fungal genus Verticillium and its relationship to insect and plant virulence, extracellular proteases and carbohydrases. Microbiology, 145: 955-63.

Biella, S., M.L. Smith, J.R. Aist, P. Cortesi, and M.G. Milgroom. 2002. Programmed cell death correlates with virus transmission in a filamentous fungus. Proceedings of the Royal Society B, 269: 2269-76.

Bilecki, L.C. 2003. Bat hibernacula in the karst landscape of central Manitoba: Protecting critical wildlife habitat while managing for resource development (Master's thesis). Retrieved 23 October 2017 from https://www.umanitoba.ca/institutes/natural_resources.

Blum, S.A.E., M.G. Lorenz, and W. Wackernagel. 1997. Mechanism of retarded DNA degradation and prokaryotic origin of DNases in nonsterile soils. Systematic and Applied Microbiology, 20: 513-21. 
Boire, N., S. Zhang, J. Khuvis, R. Lee, J. Rivers, P. Crandall ... N. Parrish. 2016. Potent inhibition of Pseudogymnoascus destructans, the causative agent of white-nose syndrome in bats, by cold-pressed, terpeneless, Valencia orange oil. PLOS ONE, 11: e0148473.

Boyles, J.G., P.M. Cryan, G.F. McCracken, and T.H. Kunz. 2011. Economic importance of bats in agriculture. Science; 332: 41-2.

Bragulat, M.R., M.L. Abarca, M.T. Bruguera, and F.J. Cabañes. 1991. Dyes and fungal inhibitors: effect on colony diameter. Applied and Environmental Microbiology, 57: 2777-80.

Braun, G., M. Vailati, R. Prange, and E. Bevis. 2012. Muscodor albus volatiles control toxigenic fungi under controlled atmosphere (CA) storage conditions. International Journal of Molecular Sciences, 13: 15848-58.

Brock, M. and W. Buckel. 2004. On the mechanism of action of the antifungal agent propionate. The FEBS Journal, 271: 3227-41.

Buchta, V. and M. Otcenásek. 1996. Factors affecting the results of a broth microdilution antifungal susceptibility testing in vitro. Zentralblatt für Bakteriologie, 283: 375-90.

Cann, A.F. and J.C. Liao. 2010. Pentanol isomer synthesis in engineered microorganisms. Applied Microbiology and Biotechnology, 85: 893-9.

Chaturvedi, S., R.J. Rudd, A. Davis, T.R. Victor, X. Li, K.A. Appler, ... V. Chaturvedi. 2011 a. Rapid real-time PCR assay for culture and tissue identification of Geomyces destructans: the etiologic agent of bat geomycosis (white nose syndrome). Mycopathologia, 172: 247256.

Chaturvedi, S., S.S. Rajkumar, X. Li, G.J. Hurteau, M. Shtutman, and V. Chaturvedi. 2011 b. Antifungal testing and high-throughput screening of compound library against Geomyces destructans, the etiologic agent of geomycosis (WNS) in bats. PLOS ONE, 6: e17032.

Cornelison, C.T., K.T. Gabriel, C. Barlament, and S.A. Crow Jr. 2014a. Inhibition of Pseudogymnoascus destructans growth from conidia and mycelial extension by bacterially produced volatile organic compounds. Mycopathologia, 177: 1-10.

Cornelison, C.T., M.K. Keel, K.T. Gabriel, C.K. Barlament, T.A. Tucker, G.E. Pierce, and S.A. Crow. 2014b. A preliminary report on the contact-independent antagonism of Pseudogymnoascus destructans by Rhodococcus rhodochrous strain DAP96253. BMC Microbiology, 14: 246-52.

Cruz, A.F., C. Hamel, C. Yang, T. Matsubara, Y. Gan, A.K. Singh ... T. Ishii. 2012. Phytochemicals to suppress Fusarium head blight in wheat-chickpea rotation. Phytochemistry, 78: 72-80.

Davey, H.M. and P. Hexley. 2010. Red but not dead? Membranes of stressed Saccharomyces cerevisiae are permeable to propidium iodide. Environmental Microbiology, 13: 163-71.

Davidson, P.M., V.K. Juneja, J.K. Branen. 2002. Antimicrobial Agents. In Branen, A.L., P.M. Davidson, S. Saliminen, and J.H. Thorngate III. Food Additives ( $2^{\text {nd }}$ ed.). Marcel Dekker Inc.:New York. 
Deising, H.B., S. Reimann, and S.F. Pascholati. 2008. Mechanisms and significance of fungicide resistance. Brazilian Journal of Microbiology, 39: 286-95.

Dickinson, J.R. 2008. Filament formation in Saccharoymyces cerevisiae - A review. Folia Microbiology, 3: 3-14.

Dionne, A., R.J. Tweddell, H. Antoun, and T.J. Avis. 2012. Effect of non-aerated compost teas on damping-off pathogens of tomato. Canadian Journal of Plant Pathology, 34: 51-7.

Dudareva, N., A. Klempien, J.K. Muhlemann, and I. Kaplan. 2013. Biosynthesis, function and metabolic engineering of plant volatile organic compounds. New Phytologist, 198: 16-32.

Dulic, V., Egeron, M., Elguindi, I., Raths, S., Singer, B., Riezman, H. 1991. Yeast endocytosis assays. Methods Enzymology, 194: 697-710.

Egger, K.N. 1995. Molecular analysis of ectomycorrhizal fungal communities. Canadian Journal of Botany, 73: S1415-22.

Elsden, S.R. and M.G. Hilton. 1978. Volatile acid production from threonine, valine, leucine, and isoleucine by Clostridia. Archives of Microbiology, 117: 165-72.

Everhart, L.P. 1972. Effects of deprivation of two essential amino acids on DNA synthesis in chinese hamster cells. Experimental Cell Research, 74: 311-8.

Farh, M., Y.J. Kim, A.H. Van, J. Sukweenadhi, P. Singh, M.A. Hug, and D.C. Yang. 2015. Burkholderia ginsengiterra sp. nov. and Burkholderia panaciterrae sp. nov., antagonistic bacteria against root rot pathogen Cylindrocarpon destructans, isolated from ginseng soil. Archives of Microbiology, 197: 439-47.

Fernando, W.G.D., R. Ramarathnam, A.S. Krishnamoorthy, and S.C. Savchuk. 2005. Identification and use of potential bacterial organic antifungal volatiles in biocontrol. Soil Biology and Biochemistry, 37: 955-64.

Ferreira, M.M., M.C. Loureiro-Dias, and V. Loureiro. 1997. Weak acid inhibition of fermentation by Zygosaccharomycs bailii and Saccharomyces cerevisiae. International Journal of Food Microbiology, 36: 145-53.

Feyder, S., J.-O. De Craene, S. Bär, D.L. Bertazzi, and S. Friant. 2015. Membrane trafficking in the yeast Saccharomyces cerevisiae model. International Journal of Molecular Sciences, 16: 1509-25.

Fialho, M.B., M.H.D. de Moraes, A.R. Tremocoldi, and S.R. Pascholati. 2011. Potential of antimicrobial volatile organic compounds to control Sclerotinia sclerotiorum in bean seeds. Pesquisa Agropecuária Brasileira, 46: 137-42.

Food and Drug Administration. 2017. Sec. 184.1081 Propionic acid. Title 21, Volume 3, Chapter 1, Part 184. Accessed 20 November 2017 from https://www.accessdata.fda.gov/scripts/ cdrh/cfdocs/cfcfr/CFRSearch.cfm?fr=184.1081.

Frick W.F., S.J. Puechmaille, J.R. Hoyt, B.A. Nickel, K.E. Langwig, J.T. Foster ... A.M. Kilpatrick. 2015. Disease alters macroecological patterns of North American bats. Global Ecology and Biogeography, 24: 741-9. 
Frick, W.F., T.L. Cheng, K.E. Langwig, J.R. Hoyt, A.F. Janicki, K.L. Parise ... A.M. Kilpatrick. 2017. Pathogen dynamics during invasion and establishment of white-nose syndrome explain mechanisms of host persistence. Ecology, 98: 624-31.

Fujita, K., A. Matsuyama, Y. Kobayashi, and H. Iwahashi. 2004. Comprehensive gene expression analysis of the response to straight-chain alcohols in Saccharomyces cerevisiae using cDNA microarray. Journal of Applied Microbiology, 97: 57-67.

Fujita, K., A. Matsuyama, Y. Kobayashi, H. Iwahashi. 2006. The genome-wide screening of yeast deletion mutants to identify the genes required for tolerance to ethanol and other alcohols. FEMS Yeast Research, 6: 744-50.

Fuller, N.W., J.D. Reichard, M.L. Nabhan, S.R. Fellows, L.C. Pepin, and T.H. Kunz. 2011. Freeranging little brown bat (Myotis lucifugus) heal from wing damage associated with whitenose syndrome. Ecohealth, 8: 154-62.

Ganesan, B., K. Seefeldt, and B.C. Weimer. 2004a. Fatty acid production from amino acids and $\alpha$-keto acids by Brevibacterium linens BL2. Applied and Environmental Microbiology, 70: 6385-93.

Ganesan, B., K. Seefeldt, R.C. Koka, B. Dias, and B.C. Weimer. 2004b. Monocarboxylic acid production by lactococi and lactobacilli. International Dairy Journal, 14: 237-46.

Gerald, J.N., J.M. Benjamin, and S.J. Kron. 2002. Robust G1 checkpoint arrest in budding yeast: dependence on DNA damage signalling and repair. Journal of Cell Science, 115: 174957.

Glass, N.L. and G.C. Donaldson. 1995. Development of primer sets designed for use with the PCR to amplify conserved genes from filamentous ascomycetes. Applied and Environmental Microbiology, 61: 1323-30.

Goode, B.L., J.A. Eskin, and B. Wendland. 2015. Actin and endocytosis in budding yeast. Genetics, 199: 315-58.

Gossen, B.D., O. Carisse, L.M. Kawchuk, H. Van Der Heyden, and M.R. McDonald. 2014. Recent changes in fungicide use and the fungicide insensitivity of plant pathogens in Canada. Canadian Journal of Plant Pathology, 36: 327-340.

Goswani, V. and A.K. Srivastava. 2001. Propionic acid production in an in situ cell retention bioreactor. Applied Microbiology and Biotechnology, 56: 676-80.

Grenni, P., F. Falconi, and A.B. Caracciolo. 2012. Microcosm experiments for evaluating natural bioremediation of contaminated ecosystems. Chemical Engineering Transactions, 28: 712.

Gruber, S. and V. Seidl-Seiboth. 2012. Self versus non-self: fungal cell wall degradation in Trichoderma, 158: 26-34.

Hazelwood, L.A., J.-M. Daran, A.J.A. van Maris, J.T. Pronk, and J.R. Dickinson. 2008. The Ehrlich pathway for fusel alcohol production: a century of research on Saccharomyces cerevisiae metabolism. Applied and Environmental Microbiology, 74: 2259-66. 
Herlemann, D.P.R., M. Labrenz, K. Jürgens, S. Bertilsson, J.J. Waniek, and A.F. Andersson. 2011. Transitions in bacterial communities along the $2000 \mathrm{~km}$ salinity gradient of the Baltic Sea. ISME Journal, 5: 1571-9.

Hoitink, H.A.J. and M.J. Boehm. 1999. Biocontrol within the context of soil microbial communities: a substrate-dependent phenomenon. Annual Review of Phytopathology, 37: 427-46.

Hosoe, T., K. Nozawa, T.C. Lumley, R.S. Currah, K. Fukushima, K. Takizawa ... K. Kawai. 1999. Tetranorditerpene lactones, potent antifungal antibiotics for human pathogenic yeast, from a unique species of Oidiodendron. Chemical and Pharmaceutical Bulletin, 47: 1591-7.

Hoyt, J.R., K.E. Langwig, J. Okoniewski, W.F. Frick, W.B. Stone, and A.M. Kilpatrick. 2015a. Long-term persistence of Pseudogymnoascus destructans, the causative agent of whitenose syndrome, in the absence of bats. EcoHealth, 12: 330-3.

Hoyt, J.R., T.L. Cheng, K.E. Langwig, M.M. Hee, W.F. Frick, and A.M. Kilpatrick. 2015 b. Bacteria isolated from bats inhibit the growth of Pseudogymnoascus destructans, the causative agent of white-nose syndrome. PLOS ONE, 10: e0121329.

Hsu, S.C. and J.L. Lockwood. 1975. Powdered chitin agar as a selective medium for enumeration of actinomycetes in water and soil. Journal of Applied Microbiology, 29: 422-426.

Huang, D.W., B.T. Sherman, R.A. Lempicki. 2009a. Bioinformatics enrichment tools: paths toward the comprehensive functional analysis of large gene lists. Nucleic Acids Research, 37: 1-13.

Huang, D.W., B.T. Sherman, R.A. Lempicki. 2009b. Systematic and integrative analysis of large gene lists using DAVID bioinformatics resources. Nature Protocols, 4: 44-57.

Hynes, S.S., O. Chaudhry, M.A. Providenti, and M.L. Smith. 2006. Development of AFLPderived, functionally specific markers for environmental persistence studies of fungal strains. Canadian Journal of Microbiology, 52: 451-61.

Idone, V., C. Tam, J.W. Goss, D. Toomre, M. Pypaert, and N.W. Andrews. 2008. Repair of injured plasma membrane by rapide $\mathrm{Ca}^{2+}$-dependent endocytosis. Journal of Cell Biology, 180: 905-14.

Johnson, L., M.L. Smith, M. Begin, B. Fraser, and J.D. Miller. 2010. Remediating office environments of spore-forming bacteria. Journal of Occupational and Environmental Hygiene, 7: 585-92.

Jones, C.B., E.M. Ott, J.M. Keener, M. Curtiss, V. Sandrin, and M. Babst. 2012. Regulation of membrane protein degradation by starvation-response pathways. Traffic, 13:468-82.

Jurjevic, Z., G.C. Rains, D.M. Wilson, and W.J. Lewis. 2008. Volatile metabolites associated with one aflatoxigenic and one nontoxigenic Aspergillus flavus strain grown on two different substrates. Phytopathologia Mediterranea, 47: 266-71. 
Kern, K., C.D. Nunn, A. Pichová, and J.R. Dickinson. 2004. Isoamyl alcohol-induced morphological change in Saccharomyces cerevisiae involves increases in mitochondria and cell wall chitin content. FEMS Yeast Research, 5: 43-9.

Kim, B.S. and B.K. Hwang. 2007. Microbial fungicides in the control of plant diseases. Journal of Phytopathology, 155: 641-53.

Kim, H.M., G. Yang, J.Y. Kim, S.J. Yoon, and B. Shin. 2017. Simultaneous determination of volatile organic compounds in commercial alcoholic beverages by gas chromatography with flame ionization detection. Journal of AOAC International, 100:1492-9.

Klindworth, A., E. Pruesse, T. Schweer, J. Peplies, C. Quast, M. Horn, and F.O. Glöckner. 2013. Evaluation of general 16S ribosomal RNA gene PCR primers for classical and nextgeneration sequencing-based diversity studies. Nucleic Acids Research, 7: 41(1): e1.

Kobaisy, M., M.R. Tellez, C.L. Webber, F.E. Dayan, K.K. Schrader, and D.E. Wedge. 2001. Phytotoxic and fungitoxic activities of the essential oil of kenaf (Hibiscus cannabinus L.) leaves and its composition. Journal of Agricultural and Food Chemistry, 49: 3768-71.

Kokurewicz, T., R. Ogórek, W. Pusz, and K. Matkowski. 2016. Bats increase the number of cultivable airborne fungi in the "Nietorperek" bat reserve in western Poland. Microbial Ecology, 72: 36-48.

Koné, S.B., A. Dionne, R.J. Tweddell, H. Antoun, and T.J. Avis. 2010. Suppressive effect of non-aerated compost teas on foliar fungal pathogens of tomato. Biological Control, 52: $167-73$.

Kono, K., A. Al-Zain, L. Schroeder, M. Nakanishi, and A.E. Ikui. 2016. Plasma membrane/cell wall perturbation activates a novel cell cycle checkpoint during G1 in Saccharomyces cerevisiae. Proceedings of the National Academy of Sciences, 113: 6910-5.

La Valle, R. and C. Wittenberg. 2001. A role for the Swe1 checkpoint kinase during filamentous growth of Saccharomyces cerevisiae. Genetics, 158: 549-562.

Langwig, K.E., W.F. Frick, R. Reynolds, K.L. Parise, K.P. Drees, J.R. Hoyt ... A.M. Kilpatrick. 2015. Host and pathogen ecology drive the seasonal dynamics of a fungal disease, whitenose syndrome. Proceedings of the Royal Society B, 282: 20142335.

Levy-Booth D.J., R.G. Campbell, R.H. Gulden, M.M. Hart, J.R. Powell, J.N. Klironomos ... K.E. Dunfield. 2007. Cycling of extracellular DNA in the soil environment. Soil Biology and Biochemistry, 29: 2977-91.

Li, Y., T. Kane, C. Tipper, P. Spatrick, and D.D. Jenness. 1999. Yeast mutants affecting possible quality control of plasma membrane proteins. Molecular and Cellular Biology, 19: 358899.

Lindner, D.L., A. Gargas, J.M. Lorch, M.T. Banik, J. Glaeser, T.H. Kunz, and D.S. Blehert. 2011. DNAbased detection of the fungal pathogen Geomyces destructans in soils from bat hibernacula. Mycologia, 103: 241-6.

Liouane, K., H.B. Abdelkader, K.B.H. Saleh, A. Debbabi, M.A. Mahjoub, K. Said, and Z. Mighri. 2009. Antioxidant and antimicrobial activity of Cotula coronopifolia (Asteraceae) growing in Tunisia. 
Liu, H., C.A. Styles, G.R. Fink. 1996. Saccharomyces cerevisiae S288C has a mutation in FLO8, a gene required for filamentous growth. Genetics, 144: 967-78.

Liu, L., Y. Zhu, J. Li, M. Wang, P. Lee, G. Du, and J. Chen. 2012. Microbial production of propionic acid from propionibacteria: Current state, challenges and perspectives. Critical Reviews in Biotechnology, 32: 374-81.

Loewith, R. 2011. A brief history of TOR. Biochemical Society Transactions, 39: 437-42.

Loewith, R. and M.N. Hall. 2011. Target of rapamycin (TOR) in nutrient signalling and growth control. Genetics, 189: 1177-201.

Lõoke, M, K. Kristjuhan, and A. Kristjuhan. 2011. Extraction of genomic DNA from yeast for PCR-based applications. Biotechniques, 50: 325-8.

Lorch, J.M., D.L. Lindner, A. Gargas, L.K. Muller, A.M. Minnis, and D.S. Blehert. 2013a. A culture-based survey of fungi in soil from bat hibernacula in the eastern United States and its implications for detection of Geomyces destructans, the causal agent of bat white-nose syndrome. Mycologia, 105: 237-52.

Lorch, J.M., L.K. Muller, R.E. Russell, M. O’Connor, D.L. Lindner, D.S. Blehert. 2013b. Distribution and environmental persistence of the causative agent of white-nose syndrome, Geomyces destructans, in bat hibernacula of the eastern United States. Applied and Environmental Microbiology, 79: 1293-1301.

Lutz, M.C., A. Robiglio, M.C. Sosa, C.A. Lopes, and M.P. Sangorrin. 2011. Two selection strategies of epiphytic native yeast with potential biocontrol capacity against postharvest pear pathogens in Patagonia. Acta Horticulturae, 909: 761-8.

Madeo, F., E. Fröhlich, M. Ligr, M. Grey, S.J. Sigrist, D.H. Wolf, and K. Fröhlich. 1999. Oxygen stress: a regulator of apoptosis in yeast. The Journal of Cell Biology, 145: 757767.

Martinez-Anaya, C., J.R. Dickinson, and P.E. Sudbery. 2003. In yeast, the pseudohyphal phenotype induced by isoamyl alcohol results from the operation of the morphogenesis checkpoint. Journal of Cell Science, 116: 3423-31.

McNeil, P.L., S.S. Vogel, K. Miyake, and M. Terasaki. 2000. Patching plasma membrane disruptions with cytoplasmic membrane. Journal of Cell Science, 113: 1891-1902.

Mendes-Ferreira, A., M. del Olmo, J. García-Martínez, E. Jiménez-Martí, A. Mendes-Faia, J.E. Pérez-Ortín, and C. Leão. 2007. Transcriptional Response of Saccharomyces cerevisiae to different nitrogen concentrations during alcoholic fermentation. Applied and Environmental Microbiology, 73: 3049-60.

Mercier, J. and J.I. Jiménez. 2007. Potential of the volatile-producing fungus Muscodor albus for control of building molds. Canadian Journal of Microbiology, 53: 404-10.

Meteyer, C.U., D. Barber, and J.N. Mandl. 2012. Pathology in euthermic bats with white nose syndrome suggests a natural manifestation of immune reconstitution inflammatory syndrome. Virulence, 3: 583-8. 
Meteyer, C.U., M. Valent, J. Kashmer, E.L. Buckles, J.L Lorch, D.S. Blehert ... A.E. Ballmann. 2011. Recovery of little brown bats (Myotis lucifugus) from natural infection with Geomyces destructans, white-nose syndrome. Journal of Wildlife Diseases, 47: 618-26.

Meyer, A.D., D.F Stevens, and J.C. Blackwood. 2016. Predicting bat colony survival under controls targeting multiple transmission routes of white-nose syndrome. Journal of Theoretical Biology, 409: 60-9.

Micalizzi E.W., J.N. Mack, G.P. White, T.J. Avis, and M.L. Smith. 2017. Microbial inhibitors of the fungus Pseudogymnoascus destructans, the causal agent of white-nose syndrome in bats. PLOS ONE, 12: e0179770.

Mira, N.P., A.B. Lourenço, A.R. Fernandes, J.D. Becker, and I. Sá-Correia. 2009. The RIM101 pathway has a role in Saccharomyces cerevisiae adaptive response and resistance to propionic acid and other weak acids. FEMS Yeast Research, 9: 202-16.

Mira, N.P., M.C. Teixeira, and I. Sá-Correia. 2010. Adaptive response and tolerance to weak acids in Saccharomyces cerevisiae: A genome-wide view. OMICS, 14: 525-540.

Motizuki, M., S. Yokota, and K. Tsurugi. 2008. Effect of low pH on organization of the actin cytoskeleton in Saccharomyces cerevisiae. Biochimica et Biophysica Acta, 179-184.

Murphy, N. and B. Bleakley. 2012. Simplified method of preparing colloidal chitin used for screening of chitinase-producing microorganisms. International Scientific Publications, $10(2)$.

Nguyen, H.Q., D.T. Quyen, S.L.T. Nguyen, and V.H. Vu. 2015. An extracellular antifungal chitinase from Lecanicillium lecanii: purification, properties, and application in biocontrol against plant pathogenic fungi. Turkish Journal of Biology, 39: 6-14.

O’Brien, P.J., A.G. Siraki, and N. Shangari. 2005. Aldehyde sources, metabolism, molecular toxicity mechanisms, and possible effects on human health. Critical Reviews in Toxicology, 35: 609-62.

O’Regan, S.M., K, Magori, J.T. Pulliam, M.A. Zokan, R.B. Kaul, H.D. Barton ... J.M. Drake. 2015. Multi-scale model of epidemic fade-out: Will local extirpation events inhibit the spread of white-nose syndrome? Ecological Applications, 25: 621-33.

Oerke, E.C. 2006. Centenary review: Crop losses to pests. Journal of Agricultural Science, 144: 31-43.

Oskiera, M., M. Szczech, A. Stępowska, U. Smolińska, and G. Bartoszewski. 2017. Monitoring of Trichoderma species in agricultural soil in response to application of biopreparations. Biological Control, 113: 65-72.

Padhi, S., I. Dias, J.W. Bennett. 2016. Two volatile-phase alcohols inhibit growth of Pseudogymnoascus destructans, causative agent of white-nose syndrome in bats. Mycology, 8: 11-16.

Pietramellara, G., J. Ascher, F. Borgogni, M.T. Ceccherini, G. Guerri, and P. Nannipieri. 2009. Extracellular DNA in soil and sediment: fate and ecological relevance. Biology and Fertility of Soils, 45: 219-35. 
Pike, B.L., S. Yongkiettrakul, M.-D. Tsai, and J. Heierhorst. 2004. Mdt1, a novel Rad53 FHA1 domain-interacting protein, modulates DNA damage tolerance and $\mathrm{G}_{2} / \mathrm{M}$ cell cycle progression in Saccharomyces cerevisiae. Molecular and Cellular Biology, 24: 27792788.

Piper, P. 1999. Yeast superoxide dismutase mutants reveal a pro-oxidant action of weak organic acid food preservatives. Free Radical Biology and Medicine, 27: 1219-27.

Pronk, J.T., A. van der Linden-Beuman, C. Verduyn, W.A. Scheffers, and J.P. van Dijken. 1994. Propionate metabolism in Saccharomyces cerevisiae: implications for the metabolon hypothesis. Microbiology, 140: 717-22.

Providenti, M.A., M. Begin, S. Hynes, C. Lamarche, D. Chitty, J. Hahn ... M.L. Smith. 2009. Identification and application of AFLP-derived genetic markers for quantitative PCRbased tracking of Bacillus and Paenibacillus spp. released in soil. Canadian Journal of Microbiology, 55: 1166-75.

Providenti, M.A., S.I. Mautner, O. Chaudhry, M. Bombardier, R. Scroggins, E. Gregorich, and M.L. Smith. 2004. Determining the environmental fate of a filamentous fungus, Trichoderma reesei, in laboratory-contained intact soil-core microcosms using competitive PCR and viability plating. Canadian Journal of Microbiology, 50: 623-31.

Pruett, S.B., L.P. Myers, and D.E. Keil. 2001. Toxicology of metam sodium. Journal of Toxicology and Environmental Health, Part B: Critical Reviews, 4: 207-22.

Pujol, M., E. Badosa, C. Manceau, and E. Montesinos. 2006. Assessment of the environmental fate of the biological control agent of fire blight, Pseudomonas fluorescens EPS62e, on apply by culture and real-time PCR methods. Applied and Environmental Microbiology, 72: 2421-7.

Raaijmakers, J.M., M. Vlami, and J.T. de Souza. 2002. Antibiotic production by bacterial biocontrol agents. Antonie van Leeuwenhock, 81: 537-47.

Rajer, F.U., H. Wu, Y. Xie, S. Xie, W. Raza, H.A.S. Tahir, and X. Gao. 2017. Volatile organic compounds produced by a soil-isolate, Bacillus subtilis FA26 induce adverse ultrastructural changes to the cells of Clavibacter michiganensis spp. sepedonicus, the causal agent of bacterial ring rot of potato. Microbiology, 163: 523-30.

Raudabaugh, D.B. and A.N. Miller. 2015. Effect of trans, trans-farnesol on Pseudogymnoascus destructans and several closely related species. Mycopathologia, 180: 325-32.

Reynolds, H.T. and H.A. Barton. 2014. Comparison of the white-nose syndrome agent Pseudogymnoascus destructans to cave-dwelling relatives suggests reduced saprotrophic enzyme activity. PLOS ONE, 9: e86437.

Reynolds, H.T., T. Ingersoll, and H.A. Barton. 2015. Modeling the environmental growth of Pseudogymnoascus destructans and its impact on the white-nose syndrome epidemic. Journal of Wildlife Diseases. 51: 318-31.

Rezende, D.C, M.B. Fialho, S.C. Brand, S. Blumer, and S.F. Pascholati. 2015. Antimicrobial activity of volatile organic compounds and their effect of lipid peroxidation and 
electrolyte loss in Colletotrichum gloeosporioides and Colletotrichum acutatum mycelia. African Journal of Microbiological Research, 9: 1527-35.

Ring, J., C. Sommer, D. Carmona-Gutierrez, C. Ruskenstuhl, T. Eisenberg, and F. Madeo. 2012. The metabolism beyond programmed cell death in yeast. Experimental Cell Research, 318: 1193-1200.

Riss, T.L., R.A. Moravec, A.L. Niles, S. Duellman, H.A. Benink, T.J. Worzella, and L. Minor. 2016. Cell viability assays. Assay Guidance Manual [Internet]. Accessed 26 November 2017 from https://www.ncbi.nlm.nih.gov/books/NBK144065/.

Robinson, M.D., J. Grigull, N. Mohammad, and T.R. Hughes. 2002. Funspec: a web-based cluster interpreter for yeast. BMC Bioinformatics, 3: 35 .

Rocha-Pino, Z., G. Vigueras, and K. Shirai. 2011. Production and activities of chitinases and hydrophobins from Lecanicillium lecanii. Bioprocess and Biosystems Engineering, 34: 681-6.

Royal Society of London. 2009. Reaping the benefits: Science and the sustainable intensification of global agriculture. Royal Society; London.

Russell, R.E., K. Tinsley, R.A. Erickson, W.E. Thogmartin, and J. Szymanski. 2014. Estimating the spatial distribution of wintering little brown bat populations in the eastern United States. Ecology and Evolution, 4: 3746-54.

Saldanha, A.J., M.J. Brauer, and D. Botstein. 2004. Nutritional homeostasis in batch and steadystate culture of yeast. Molecular Biology of the Cell, 15: 4089-104.

Sánchez, S. N., and M. Königsberg. 2006. Using Yeast to Easily Determine Mitochondrial Functionality with 1-(4,5-Dimethylthiazol-2-yl)-3,5-diphenyltetrazolium Bromide (MTT) Assay. Biochemistry and Molecular Biology Education, 34: 209-212.

Sánchez-Ortiz, B.L., R.E. Sánchez-Fernándes, G. Duarte, P. Lappe-Oliveras, and M.L. MacíasRubalcava. 2016. Antifungal, anti-oomycete and phytotoxic effects of volatile organic compounds from the endophytic fungus Xylaria sp. Strain PB3f3 isolated from Haematoxylon brasiletto. Journal of Applied Microbiology, 120: 1313-25.

Saqcena, M., D. Menon, D. Patel, S. Mukhopadhyay, V. Chow, and D.A. Foster. 2013. Amino acids and mTOR mediate distinct metabolic checkpoints in mammalian G1 cell cycle. PLOS One, 8: e74157.

Schmidt, A., T. Beck, A. Koller, J. Kunz, and M.N. Hall. 1998. The TOR nutrient signalling pathway phosphorylates NPR1 and inhibits turnover of the tryptophan permease. The EMBO Journal, 17: 6924-31.

Schneider, C.A., W.S. Rasband, and K.W. Eliceiri. 2012. NIH Image to ImageJ: 25 years of image analysis. Nature Methods, 9: 671-5.

Schulz, S. and J.S. Dickschat. 2007. Bacterial volatiles: the smell of small organisms. Natural Product Reports, 24: 814-42.

Semchyshyn, H.M., O.B. Abrat, J. Miedzobrodzki, Y. Inoue, and V.I. Lushchak. 2011. Acetate but not propionate induced oxidative stress in bakers' yeast Saccharomyces cerevisiae. Redox Report, 16: 15-23. 
Sharma, R.R., D. Singh, and R. Singh. 2009. Biological control of postharvest diseases of fruits and vegetables by microbial antagonists: A review. Biological Control, 50: 205-21.

Shuey, M.M., K.P. Drees, D.L. Lindner, P. Keim, and J.T. Foster. 2014. Highly sensitive quantitative PCR for the detection and differentiation of Pseudogymnoascus destructans and other Pseudogymnoascus species. Applied and Environmental Microbiology, 80: 1726-31.

Slater, T.F., B. Sawyer, and U. Sträuli. 1963. Studies on succinate-tetrazolium reductase systems III. Points of coupling of four different tetrazolium salts. Biochimica et Biophysica Acta, 77: 383-93.

Smirnova, J.B., J.N. Selley, F. Sanchez-Cabo, K. Carroll, A.A. Eddy, J.E.G. McCarthy ... M.P. Ashe. 2005. Global gene expression profiling reveals widespread yet distinctive translational response to different eukaryotic translation initiation factor 2B-targeting stress pathways. Molecular and Cellular Biology, 25: 9340-9.

Sommer, C., C. Strähle, U. Köthe, F.A. and Hamprecht. 2011. ilastik: Interactive Learning and Segmentation Toolkit. Eighth IEEE International Symposium on Biomedical Imaging (ISBI) Proceedings; 2011: 230-3. 2011 Mar 30-Apr 2; Chicago, IL.

Stinson, A.M., N.K. Zidack, G.A. Strobel, and B.J. Jacobson. 2003a. Mycofumigation with Muscodor albus and Muscodor roseus for control of seedling diseases of sugar beet and verticillium wilt of eggplant. Plant Disease, 87: 1349-54.

Stinson, M., D. Ezra, W.M. Hess, J. Sears, and G. Strobel. 2003b. An endophytic Gliocladium sp. of Eucryphia cordifolia producing selective volatile antimicrobial compounds. Plant Science, 165: 913-22.

Stowe, R.P, D.W. Koenig, S.K. Mishra, and D.L Pierson. 1995. Nondestructive and continuous spectrophotometric measurement of cell respiration using a tetrazolium-formazan microemulsion. Journal of Microbial Methods, 22: 283-92.

Strobel, G.A., E. Dirkse, J. Sears, and C. Markworth. 2001. Volatile antimicrobials from Muscodor albus, a novel endophytic fungus. Microbiology, 147: 2943-50.

Tagnon, M.D. and K.O. Simeon. 2017. Aldehyde dehydrogenases may modulate signaling by lipid peroxidation-derived bioactive aldehydes. Plant Signaling and Behaviour, 12: e1387707.

Taylor, E.J., S.G. Campbell, C.D. Griffiths, P.J. Reid, J.W. Slaven, R.J. Harrison ... M.P. Ashe. 2010. Fusel alcohols regulate translation initiation by inhibiting eIF2B to reduce ternary complex in a mechanism that may involve altering the integrity and dynamics of the eIF2B body. Molecular Biology of the Cell, 21: 2202-16.

Thomsson, E., L. Gustafsson, and C. Larsson. 2005. Starvation response of Saccharomyces cerevisiae grown in anaerobic nitrogen- or carbon-limited chemostat cultures. Applied and Environmental Microbiology, 71: 3007-13.

Toju, H., A.S. Tanabe, S. Yamamoto, and H. Sato. 2012. High-coverage ITS primers for the DNA-based identification of ascomycetes and basidiomycetes in environmental samples. PLOS ONE, 7: e40863. 
Tong, A.H., M. Evangelista, A.B. Parsons, H. Xu, G.D. Bader, N. Pagé ... C. Boone. 2001. Systematic genetic analysis with ordered arrays of yeast deletion mutants. Science, 294: 2364-8.

Trevors, J.T., J.D. van Elsas, L.S. van Overbeek, and M.-E. Starodub. 1990. Transport of a genetically engineered Pseudomonas fluorescens strain through a soil microcosm. Applied and Environmental Microbiology, 56: 401-8.

Tripathi, P. and N.K. Dubey. 2004. Exploitation of natural products as an alternative strategy to control postharvest fungal rotting of fruits and vegetables. Postharvest Biology and Technology, 32: 235-45.

U.S. Fish and Wildlife Service. 2016. White-nosesyndrome.org: A Coordinated Response to the Devastating Bat Disease. Accessed 8 September 2016 from https://www.whitenosesyndrome.org/.

U.S. Fish and Wildlife Service. 2018. White-nosesyndrome.org: A Coordinated Response to the Devastating Bat Disease. Accessed 21 March 2018 from https://www.whitenosesyndrome.org/.

Ullah, A., R. Orij, S. Brul, and G.J. Smits. 2012. Quantitative analysis of the modes of growth inhibition by weak organic acids in Saccharomyces cerevisiae. Applied and Environmental Microbiology, 78: 8377-87.

Unger, M.W. and L.H. Hartwell. 1976. Control of cell division in Saccharomyces cerevisiae by methionyl-tRNA. Proceedings of the National Academy of Science, 73: 1664-8.

Vanderwolf, K.J., D. Malloch, and D.F. McAlpine. 2015. Fungi associated with over-wintering tricoloured bats, Perimyotis subflavus, in a white-nose syndrome region of eastern Canada. Journal of Cave and Karst Studies, 77: 145-51.

Vanderwolf, K.J., D.F. McAlpine, G.J. Forbes, and D. Malloch. 2012. Bat populations and cave microclimate prior to and at the outbreak of white-nose syndrome in New Brunswick. Canadian Field-Naturalist, 126: 125-34.

Verant, M.L., C.U. Meteyer, J.R. Speakman, P.M. Cryan, J.M. Lorch, and D.S. Blehert. 2014. White-nose syndrome initiates a cascade of physiologic disturbances in the hibernating bat host. BMC Physiology, 14: 1-10.

Verant, M.L., E.A. Bohuski, J.M. Lorch, and D.S. Blehert. 2016. Optimized methods for total nucleic acid extraction and quantification of the bat white-nose syndrome fungus, Pseudogymnoascus destructans, from swab and environmental samples. Journal of Veterinary Diagnostic Investigation, 28: 110-8.

Verant, M.L., J.G. Boyles, W. Waldrep Jr., G. Wibbelt, and D.S. Blehert. 2012. Temperaturedependent growth of Geomyces destructans, the fungus that causes bat white-nose syndrome. PLOS ONE, 7: e46280.

Vogel, V.H. 1956. A convenient growth medium for Neurospora (Medium N). Microbial Genetics Bulletin, 13: 42-3. 
Wagih O, Usaj M, Baryshnikova A, VanderSluis B, Kuzmin E, Costanzo M... Parts L. 2013. SGAtools: One-stop analysis and visualization of array-based genetic interaction screens. Nucleic Acids Res. 41:W591-6.

Wang, C., Z. Wang, X. Qiao, Z. Li, F. Li, M. Chen ... H. Cui. 2013. Antifungal activity of volatile organic compounds from Streptomyces alboflavus TD-1. FEMS Microbiology Letters, 341: 45-51.

Warnecke, L., J.M. Turner, T.K. Bollinger, J.M. Lorch, V. Misra, P.M. Cryan ... C.K.R. Willis. 2012. Inoculation of bats with European Geomyces destructans supports the novel pathogen hypothesis for the origin of white-nose syndrome. Proceedings of the National Academy of Sciences; 109: 6999-7003.

Weber, F.J. and J.A.M. de Bont. 1996. Adaptation mechanisms of microorganisms to the toxic effects of organic solvents on membranes. Biochimica et Biophysica Acta, 1286: 225-45.

Wendt-Potthoff, K., H. Backhaus, and K. Smalla. 1994. Monitoring the fate of genetically engineered bacteria sprayed on the phylloplane of bush beans and grass. FEMS Microbiology Ecology, 15: 279-90.

White, T.J., T. Bruns, S. Lee, J. Taylor. 1990. Amplification and direct sequencing of fungal ribosomal RNA genes for phylogenetics. In Innis MA, Gelfand DH, Sninsky J, and White TJ (editors). PCR Protocols: A Guide to Methods and Applications. New York: Academic Press; 1990. pp. 315-22.

Wiederkehr, A., Meier, K.D., and Riezman, H. 2001. Identification and characterization of Saccharomyces cerevisiae mutants defective in fluid-phase endocytosis. Yeast, 18: 759773.

Wu, X., L. Liu, and M. Huang. 2011. Checkpoints studies using the budding yeast Saccharomyces cerevisiae. Methods in Molecular Biology, 782: 47-57.

Yang, R.S., K.L. Witt, C.J. Alden, and L.G. Cockerham. 1995. Toxicology of methyl bromide. Reviews of Environmental Contamination and Toxicology, 142: 65-85.

Yun, J. and D.G. Lee. 2016. A novel fungal killing mechanism of propionic acid. FEMS Yeast Research, 16: fow089.

Zeilinger, S., S. Gruber, R. Bansal, and P.K. Mukherjee. 2016. Secondary metabolism in Trichoderma - Chemistry meets genomics. Fungal Biology Reviews, 30: 74-90.

Zhang, J.-H., H.-L. Sun, S.-Y, Chen, L. Zeng, and T.-T. Wang. 2017. Anti-fungal activity, mechanism studies on $\alpha$-phellandrene and nonanal against Penicillium cyclopium. Botanical Studies, 58: 13.

Zhang, T., T.R. Victor, S.S. Rajkumar, X. Li, J.C. Okoniewski, A.C. Hicks ... V. Chaturvedi. 2014. Mycobiome of the bat white nose syndrome affected caves and mines reveals diversity of fungi and local adaptation by the fungal pathogen Pseudogymnoascus (Geomyces) destructans. PLOS One, 9: e116149.

Zhang, T., V. Chaturvedi, and S. Chaturvedi. 2015. Nwarnovel Trichoderma polysporum strain for the biocontrol of Pseudogymnoascus destructans, the fungal etiologic agent of white nose syndrome. PLOS ONE, 10: e0141316. 
Zukal, J., H. Bandouchova, J. Brichta, A. Cmokova, K.S. Jaron, M. Kolarik ... N. Martínková. 2016. White-nose syndrome without borders: Pseudogymnoascus destructans infection tolerated in Europe and Palearctic Asia but not in North America. Scientific Reports, 6: 19829.

Zunino, M.P., J.M. Herrera, R.P. Pizzolitto, H.R. Rubinstein, J.A. Zygadlo, and J.S. Dambolena. 2015. Effect of selected volatiles on two stored pests: The fungus Fusarium verticilliodes and the maize weevil Sithophilus zeamais. Journal of Agricultural and Food Chemistry, 63: 7743-9. 